$b$

PM1641
278553
1900 

Lang. 

KWAGU'L。

A. 



\section{THE GOSPEL}

ACCORDING TO

\section{S T. M A R K}

TRANSLATLD INTO

\section{THE KWĀGUTL I ANGUAGE,}

NORTH OF VANCOUVER ISLAN̦D.

LONDON :

PRINTED FOR THE

BRITISH AND FOREIGN BIBLE SOCIETY. 1900. 


$$
\begin{aligned}
& \text { PM/641 } \\
& 278553 \\
& 1900
\end{aligned}
$$$$
+1+1+1+1
$$

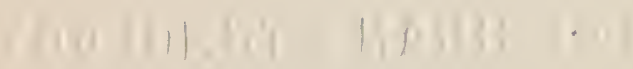

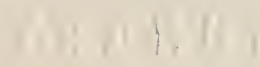




\section{S T. M A R K.}

CHAPTER I.

K̄ì da gālābāya sī da ekī wātldums Jesus C̄hrist, yik Kwanūqa sints Ike Gīkumī ;

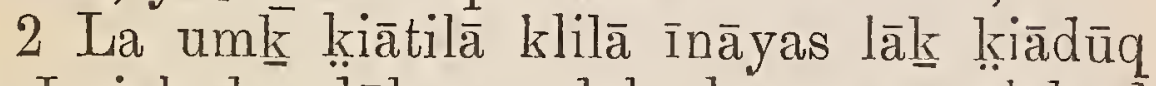
as Isaiah knā dūk-zas, dok, la mun yālāk-îd tsin hīlauk-stāyi kā les gāgālatl gīwā yūs, kā tihyīla kās lākn̄is la-ās klūs.

3 Yik̄i da nīḳiāle lāknà lūblabīs, qātlātla

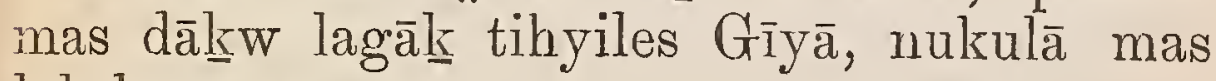
lāk kāyāsa sī.

4 Gă $\underline{k}$ wūtlī John, lūtlì baptize lākna lūblabīs, glīkss-ālas baptizīnāyas sa māyātā kā dĩgiklilāqīis sīs yekīnāyī.

$5 \mathrm{Wa}$ hīmīs lūtl la-ās wūtl lākī yisa nāhwūtla gāyūtl lāk Judæa gla wa gāayūtl lāk Jerusalem, wa hīmīs lūtl nāhwā um baptíze-īd

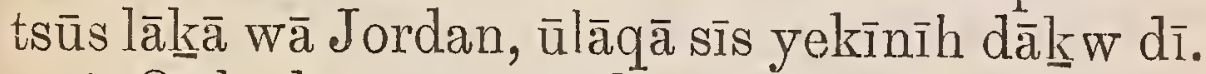

6 Qītlqela nūq wūtl tī John-nas saye sa camel, la mīs wasīgiq sa qazī wasīgānū, hī̄ mīs humã yūtl tsĩ da locust gla wì da ăklī zis honey; 
7 Lūtlī glīkss-āla, nīkia, gāk klī da tloqìmasa kāwāya un, yikun ḳisā hîtlū wās kun au-glā

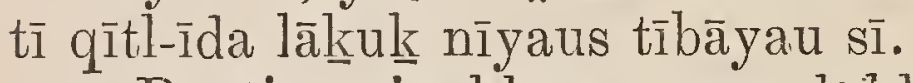

8 Baptize sin kla sa wāpī lūkl; lā-glā tā klī baptize klūkl yisī da Holy Spirit.

9 Gāk w wâtlī Jesus geh-īd lāk Nazareth kās gākēi ]āk Galilee, la baptize-ìd tsūs John lāk Jordan.

10 Wa gil mīs gāk lostā lākēa wãa, la ās dūqilā knī da īkī qukns-ulīsā, gāka-ā sī da Spirit putl-tsum duk:

11 Gākza-ā sa nīkniāle lāknā ì $k \bar{i}$, sū mun tlāhwil KK wanūqs, sū mī sin eḳīkums. āklì.

12 Hīh ìdā mì sì da Spirit là-mas uk lāknā

13 Mūskum gūstau pun hwās tā hī gāk lī da ăklī gwānā sūs Satan, gīgilkī knā tla-ulwīs gilgā-ūmas, lūtlī da angels aākssīlāk.

14 đI Wa yikss lā $\bar{i}$ John wulh-îd tsū wā, găkz-a ā sī Jesus lākn Galilee glīkns-ālà sī da ek wātldum sints Ike Gīkumī,

15 Nìkia, la mūk lastiu-dū $\underline{k}$ da nālākn, gāâk

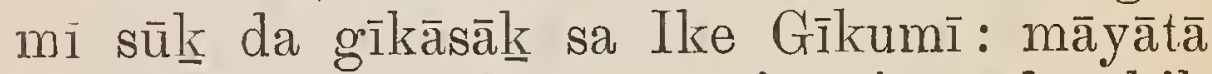
laga, hī mīs kās kn̄isa ūs wiyūqis gāda ekik wātldumā.

16 Là hī-nāqil kāsa-īsil lākēa zilātlas Galilee,

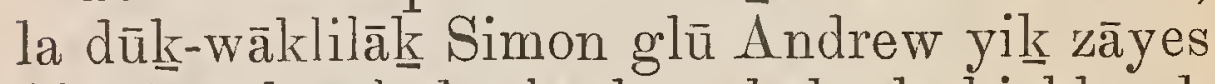

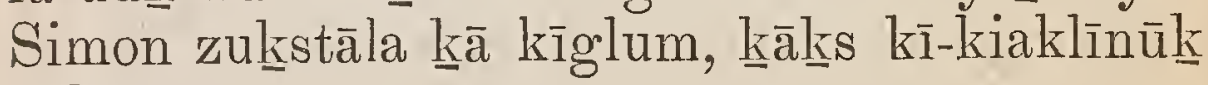
dāknwa i.

17 Lì Jesus nīk lāh dāk $\underline{w} w k$, kī̄āh dāknw 
lā, lāskum ì gāknun, la mì sin lā-kl kī-kiaklī-

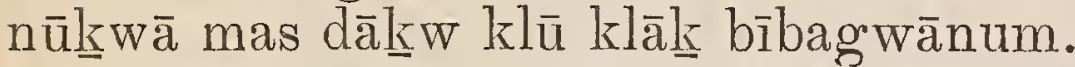

18 Wa hīh-īdih dāknw mīs tlowāklā kīis kīkīglum, kās le lāskum-īk.

19 Wa gil mīs là qāqīs-gīlātla, la à kea ās dūk -wāklilāk James ̌wanūqas Zebedee, glū John yik zāyes yiknā qizikssālā umh de kna à

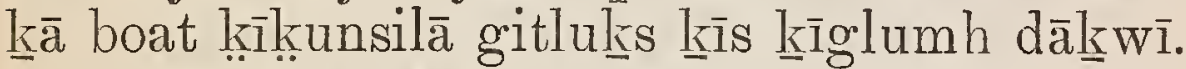

20 Wa hīh-īdā mīs klīlālāk : wa lāh dāknw mìs tlowāklā kīis ümp dākwī Zebedee qāknsaulāk lāksà boat gla wī da hīlānumh dāknwās, kās le lāskum-īk.

21 T Wa lāh dāk $\underline{k} w$ lāk Capernaum: wa

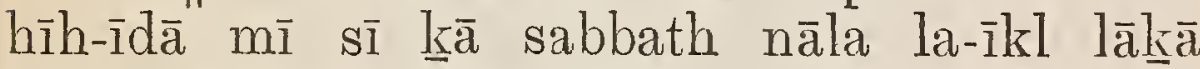
synagogue kās glīkss-ālì.

22 Lāh dāknw knunyāsas wātldum as : ka

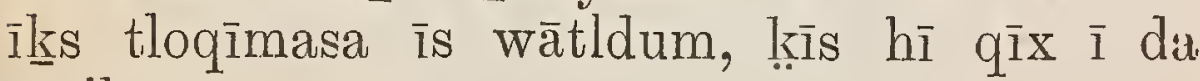
scribes.

23 Numūq tī da bagwānum hī gāâk lī da synagogue uǩknūgwād tsa yāksamī spirit; la qaqātl-tse,

24 Nīkia, qā̄ā gatāla gākzunūh; mā zau nu-hwūs, yūkl Jesus yis Nazareth? la mas gāk kās kīiākia ùs gāknunūhwā? mātl-tela mun klūkl, yūkl Ekk KKwanūq sa Ike Gīkumī.

25 Lī Jesus bulka-gātl, nīkia, ḳwīklātlāla, kīlāga lawe lāknwā bagwānumk .

26 La à sī da yāksamī spirit yāwīh-īdalāk, lā kna à hāsil qaqātl-tse, gā̄ka ās lāwe lāknā bagwānum. 
27 Läh dākn nāhwā um k kunyāsāa, wuitl

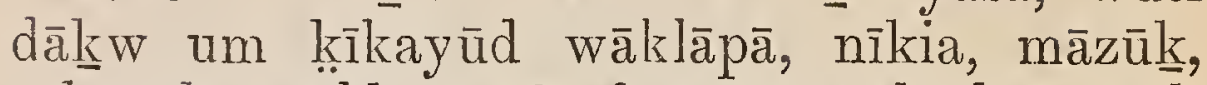

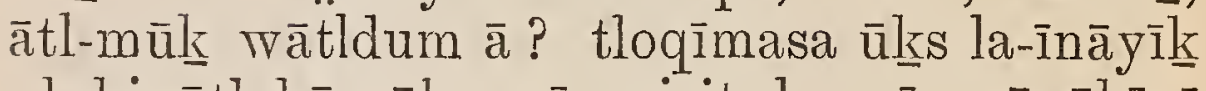
uk-kরigātl knà yāksamī spirit, la mī̄s nānākīgī uniq.

28 Wa hīh-īdā mīs là ziḳiālum lāknā nāhwā awīnāgwīs lāk Galilee.

29. Gilh dāknw mīs gāk lāwils lākēa synagogue, ha-ìklilā mīs lāk gūquas Simon glū Andrew, wa-ūq maula nūqs James glū John. 30 Là tā zihḳi abumpas kunum as Simon;

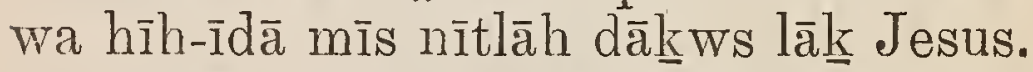

31 Wa gākna às lāk, lā dāh-īduk àyāsaus, kās dāgūstau lītlīk; wa hīh-ìdā mī sì zihḳūulumh-des kīyohwìd lāk, wa hĩ mī sa zidākī la humgīiāh dāknwuk.

32 We kzị da lā zāqa la à sì da klīsilā lunsā,

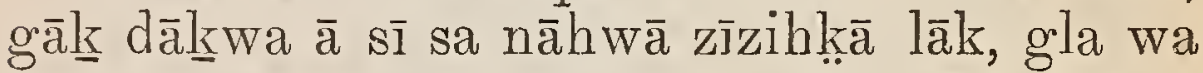
nāhwā ulknūgwā tsa devils gāk yūh dāknws lāk.

33 Wa gāk mīs wīlì da nāhwa bagwānum

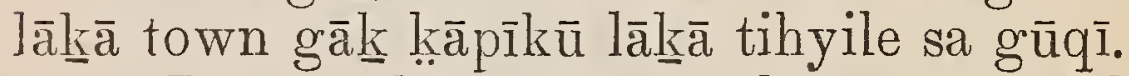

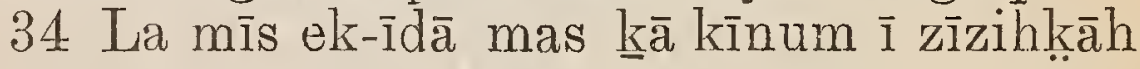
di sa nāhwā-umh dī kās qīxdums zihkūlum

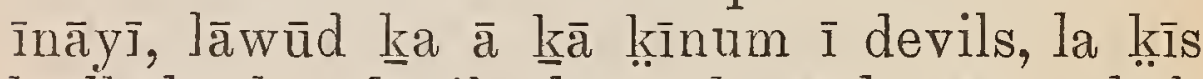
hîtlkạla knà devils kà yākরugātl nūqīs, kāh dākwuks mātl-tela ma àk.

35 Wa knā la kaāla, knīs ma ī glaul kās nāhìdī, la às glăk k-wīda kās lāwilsī, la kās-īd lā lākēa lūbīs awīnāgơwis, kās hawākn-ulī lāk. 
36 La āsī Simon gla wīs wa-ūq maula lāa kās lāskumā ȳ̄k.

37 Gilh đāknw mīs khāk, lāh dāknw nīk yuk, la ums āle sū sa nāhwāk bagwānum à.

38 La nīk lāh dāknwuk, wī-hyints la-ās

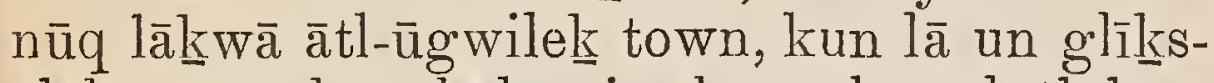

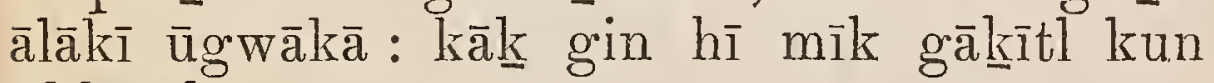
glīkss-ālì.

39 Wa la mīs lā-laīklā lāk synagogue dāknwas lāk wāzikīzās mas Galilee, glìns-ātā glū ] $\bar{a} w \bar{u} d \bar{l} l a ~ k \bar{a}$ devils.

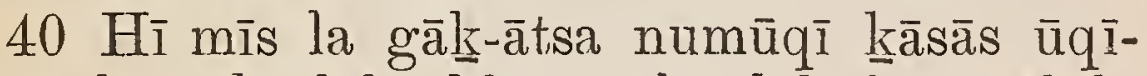
nāyī hawāk-ulāk, klāq-wālìs lāk kās nīkīk, gì mī lāknā kūs nīk lāk, ek-ìdā mas um lāk wīsis gāknun.

41 La āsī Jesus wīwozịk-ìdis, la sāh-īd kās pāh-īdìk, la nīk yuk, nīk mun, wīga ekIduk.

42 Wa hīh-ìdā mì sī da zihḳūlumh des kīyohwìd lāk, la mīs ek-ìda.

43 La mīs tloqāl hiyāklū-lāk, lā yālāka wilsāk.

44 Nìk yuk, yāklaula kās kīyosa ūs nītlā sa wa lāk ungwe bagwānum, au uma hī-

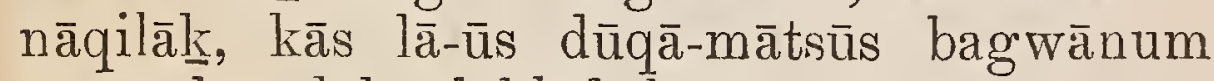
innāyā kūs lākē labled, kās zaw ūsā sa qayū wūtlas Moses kā qīgīlas kā ìs lā-īnāyūs ekìda, kā māmātltīkīh dākzws.

45 Au mīs lā-wils, kās le zāzāḳiālāh ìis, la gwîtl-īdā masuk, lāgītl-ts kīyos là qīh-īda 
àsī Jesus hānātl nītl-tsumātla lākulisā knā tītown $\overline{1}$, au gītl mas la hī gāak lì da lūblabīs

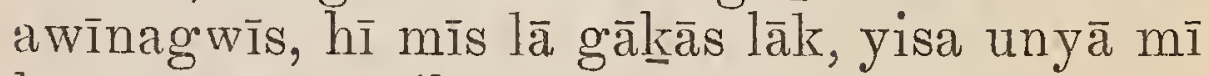
kas gīgāya-nāqilasā.

\section{CHAPTER II.}

GiL mìs gāk $\bar{i}$ tīd lāk Capernāum, lā khātl

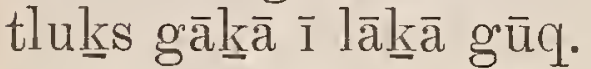

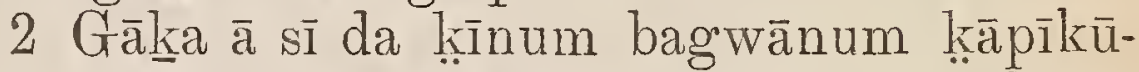
nāqil lāk lūbītl tsa gūūi kā wāknaās dāknwās, kīyos, kīyos au glāt lāknā tihyilā, lā glīkss-āla sa wātldum ì lāh dāknwuk.

3 Wa gāk dāk wī sa bagwānum tlītlil- k̦inā, da-āq sa mūqì

4 Wa gilh dākn mìs kìyos qĩh-īdaās gākāklilas lāk, kā ì da kīnum bagwānum tākiapā, lāh dāknw uk kūuluk sele sa gūqi qaīlats: wa gilh dāknw mīs lāh-sau mas ǩis la-īnāyi tsūqāk,

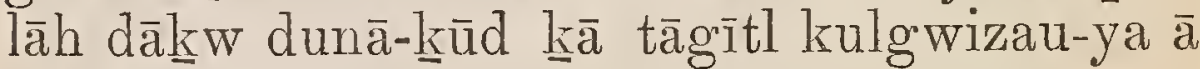
tsa tlìtlil-kinī.

5 Lī Jesus dūqilāk ūqizālazīh dāk

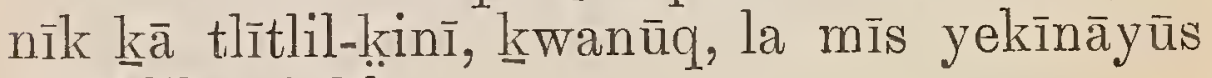
dìgiklilāq lūkl.

6 Kwazītl tī da gāyūtlī lāknā scribes, ninnīnkīkulāa,

7 Māzì hī gītla sūk qịkiālūk da bagwānum

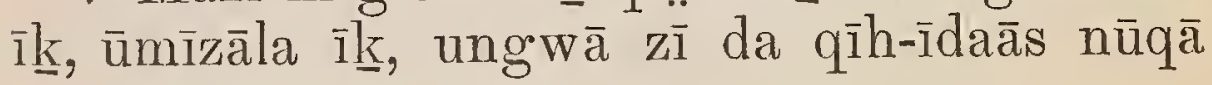


dỉgiklilūduk yeḳ̄nāyī, hīga ma à sints Ike Gîkumī?

8 Hīh-īdā mī sī Jesus dūḳwāklilā kīkns nīnḳīkulāh dāknwa ì, nīk lāh dāknwuk, māzīs

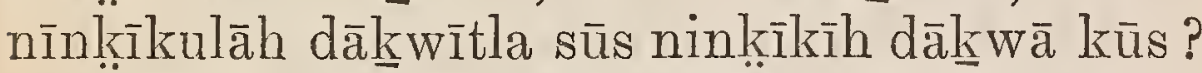

9 Wìzì da hūtlumātle, lāk nīk yāk gāda zihknāk, la mīs yeḳ̄ināyūs dīgiklilāq, glū nīkia kuk', glāk-wilìtl laga, kās dāh-j̄da ùsā knūs tāgītla kūs, kās kās-īda ùs?

10 Kās kauklilā ūsā kñ Kwanūqā sa bağwānum mākns ǔnūgwāda āsā tlāhwāyì

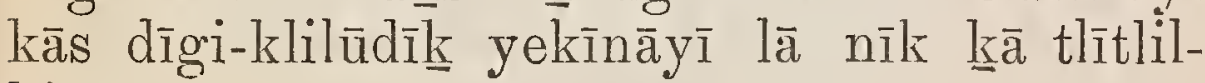
kরinī,

11 Lamun nīkiūkl, glāknwilītl laga kās dāhìda ùsā knūs tāgîtlā kūs, kās lālāga ùs lāknīs gūqa ūs.

12 Là glākwilìtlāa, hīh-īdā mīs dāh-ìd knīs tāgìtlī, kāas le kās-īd wīlpātl-tūtl dākn ums; lāh dākn nāhwā um kzunyāsā, hyāshyîlā knunts Ike Gìkumī, nīkia, hì munts attī num puna dūqilāk yau qīx ūkي.

13 đI La ās îtīd kās-īd lāk uk gākna à sa kīnum bagwānum lāk, la mīs glìksàl lāh dāknwuk.

14 Wa yilkss lā i ke-nāqila, lā dūkn-wāklìāk Levi kwanūqas Alphæus qa-ītl lāknà hätlākulas, la nīk yuk, kīla legī gā kzun : la glāknwilītl kās lāskumāyīk.

15 Wa yikss la ì qa-ītl lāk gūuas humāpā, kīnum tì da hì-hâtlākulilgisī gla wa yaīksāmì 
qazìtl wūts hì mī sīs disciples: yikns kīnuma $\overline{1}$, lāh dāknww mīs lāskum ìk.

16 Gì mī sì da scribes gla wa Pharisees dūqila kīks la ì humāp gla wa yaīksāmī hī mī

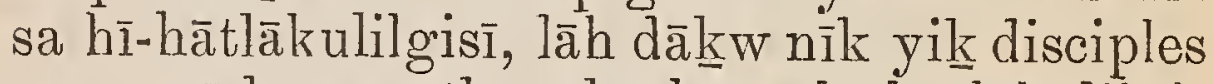
as, māzī humāpitla sūk gla wa hî-hātì̄kulilgisì yū mī sa yaîksāmì k ?

17 Wa gil mī sī Jesus wuklilā knīk, la nīk lāh dāknwuk, yih dākn kni da ek māk̂ss kīyosā ì

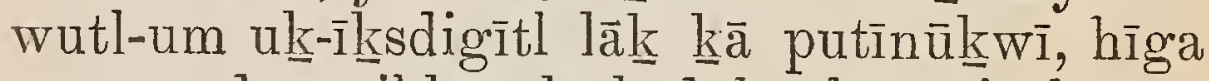

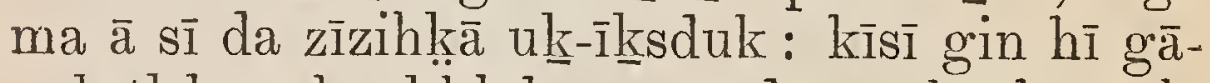
gaǩîtl kun he klīlālasū wì da es-ekī, he âglà sī da yaīksāmī kā māyātīs.

18 Wa lì disciples as John hī mī sī da

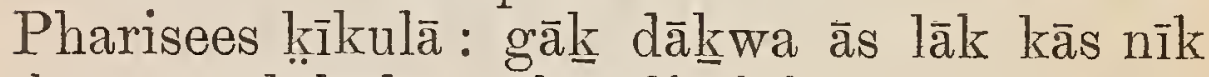
īk, māzì kịikulā gītlas disciples as John glū disciples asa Pharisees, lā glā tūs disciples àkūs kīs kīikulā?

19 Lì Jesus nīk lāh dāknwuk, qīh-īdaās nūq ma ì ginginānuma sa māle-klī knīkulākns kīs ma ì gwîtl-ìdih dākn gla wa tlāwunum klī ? yik wā̄āsduma sī da tlāwunum klī kupetla

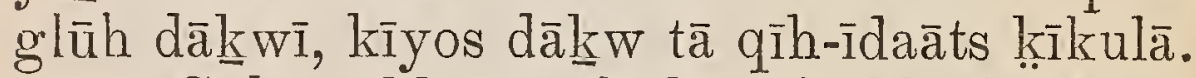

20 Gāk-umkl wīs glī da nālā kla, kū lā klī da tlāwunum uk-ittsūkl lāh dāknwuk, wa lā-kl wīs glă knīkulāh dāknw-kl.

21 Kīyos bag'wānum ḳunga-āklilūdisa ālūmasī yāwābazū lāknā lā pīkā qîtlqela: āklī da

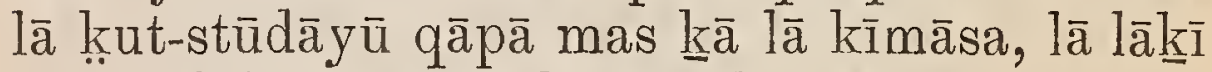

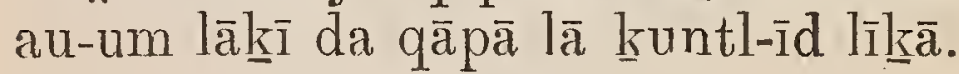


22 Kīyos umka $\bar{a}$ wīs bagwānum gwukzūd tsa ālūmas wine lākn $\bar{a}$ lā kīmas wine-àze; āklī

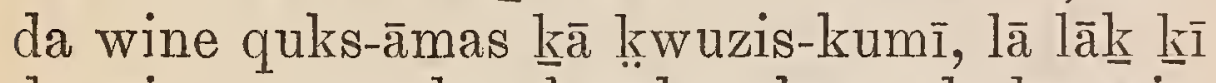
da wine au um līiyohwīda, gla wī da k़wuziskumī: gwukzūdāyau à glă sa ālūmasì wine lākēa ālūmas ḳwuzis-kumā.

23 ๆ Wa yikss lā i kās-ìd kā sabbath nāla

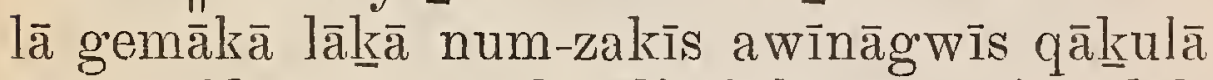
tsa zìzidanū; wa lì disciples as yilks lāh

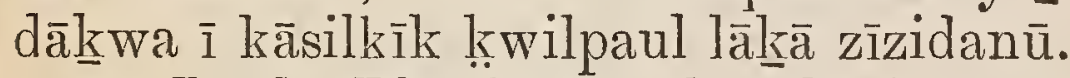

24 Lì da Pharisees nīk yik, dokn, māzī hì gītla sūk qīgīlā kwā sabbath ìk nālā yiks kīsa ì hìtlkūlum he qīgīlà unkīi ?

25 Lā nīk lāh dāknwuk, kisas k kiāḳiāduq

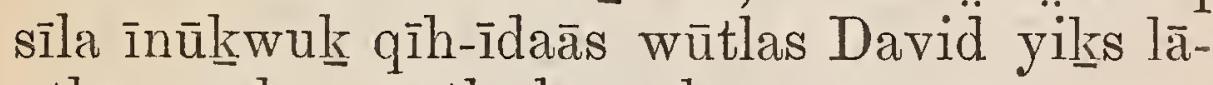
ūtla pūsḳā, yūtl kī, gla wīs wa-ūq mau lūtlā ?

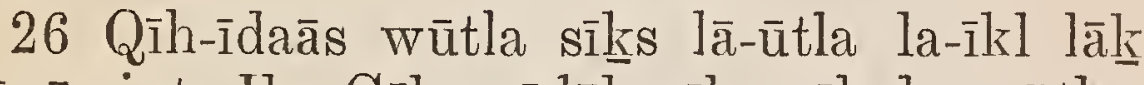
gùqā sints Ike Gīkumī lāk gìnumīh dum ūtlas priestī da Abiathark klūtla, Iūtlī humh-īdà mūtl kīa hīma-ūmas wütla ga- ittl lāk, yikā kīs zīmasī humes ūgwile lāk kā priest, la mūtl ka à wì sī zaw kî̀s wa-ūq mau lūtla.

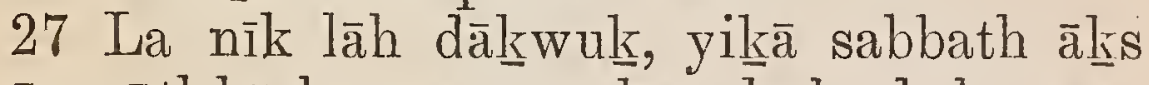

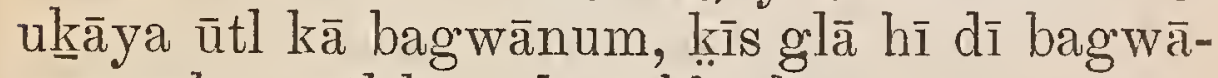

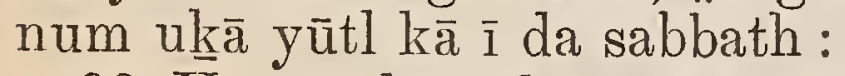

28 H$_{\overline{1}}$ mīs lā-gītl tsa Kwanūqa sa bagwānum gīkumī um lka à sa sabbath. 


\section{CHAPTER III.}

LA îtīd la-īkl lāknā synagogue; numūq tī da tlilkịiutlzāna bag wānum hì gāk lì.

2 Lāh dāknw dūqātlāk kīis kla ì ek-īdā masuk kzā sabbath nāla, kās hītlā kna ās dāknw ]ākzuk kās sīnātuk.

3 La nīk kī da tlilḳiūtlzāna bagwānum, glāk-wukau lìtl las.

4 La nīk lāh dāknwuk, ek mā ì kā ukssū-wì sī da ekī qaīnī knā sabbath nāla, glū hī ulkssūwī yākssamā? wīnī da ekiā lāk qãqila-unk glū tlilāmas duma? au mīs la k़wīklātlāh dāknwā.

5 Wa gil mīs lā dūqilkund tlāwīs dāknwuk, zihyilīs naukāyi kā au-īnīh dāknw mas pāpĩzā kīis nīnaukīh dāknwī, la nīk lkā bag'wānum, sāh-īdaga tsūs āyasau kūs: la sāh-īdis; lī àyasaus nākumzauh-īda.

6 Lī da Pharisees hūkūwilsa, wa hīh-īdih dāknw mīs la knwīkul gla wa Herodians kās qīh-ìdaās dāk kn kā tlilìs.

7 Lì Jesus gla wīs disciples lāk uk̄ā sa zalătlī : lì da kīnum bagwānum lk kā geh-īdì lāk Galilee lāskum ìk, gla wa geh-ìdì lāk -Tudra,

8 Hī mì sa geh-īdī lāk Jerusalem gla wa geh-īdì lāk Idumæa glū upsūtas Jordan; glūh

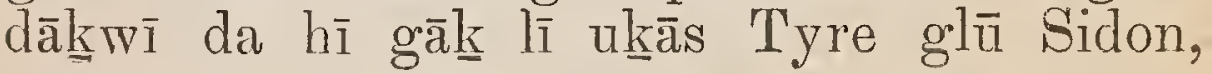


klūm kīnum bagwānumā, yilkss lā ì khālāk

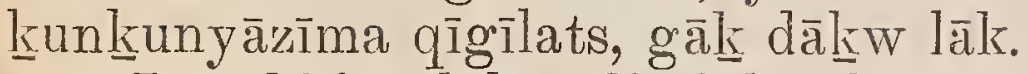

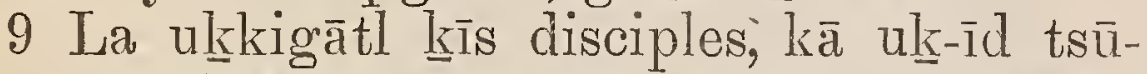

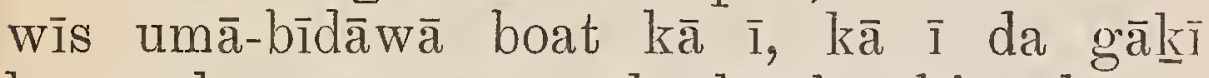
kīnum bagwānum, g'wāknutla àk tākiapuk.

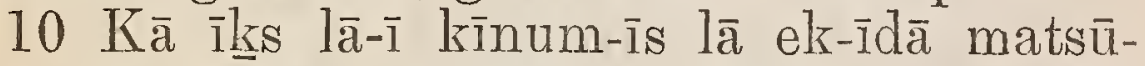

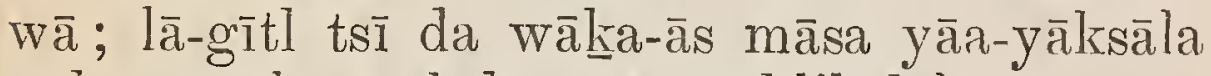

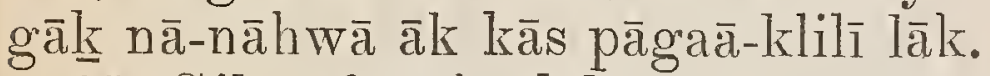

11 Gil nāhwāh dākn mā ì da ya-īksāmī

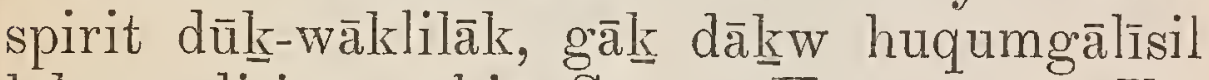
lāk, qāglitiwī, nīkia, Sūum Ǩwanūq sa Ike Gīkumī.

12 La nì lāh dāknwuk kā kīs kiasī lāks kạ̄āgīla mas lākss.

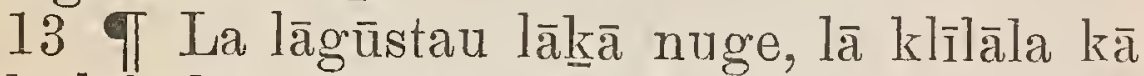
gāk lāk kīis qayūwī kās klīlāla-sū: wa lāh dāknw lāk.

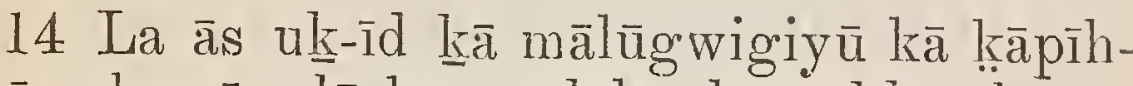

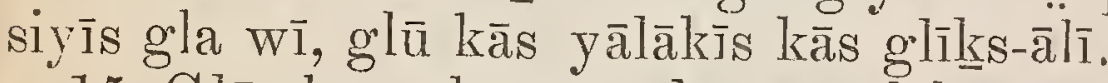

15 Glū kà uknūgowādi sīs tłāhwāya kā lāwelì sì knā devil-sì :

16 Là glīk-ìdis Peter lāk Simon;

17 Hīmīsì James knwanūqas Zebedee, hīmīsī John zāyes James; hīmīs gî̄ îkīd tsū sīs Boanerges, sāsums qunhwā nīkīkns nīkia ì :

18 Hīmīsì Andrew, glū Philip, glū Bartholomew, g]ū Matthew, glū Thomas, glū James kwanūqas Alphæus, glū Thaddæus, glū Simon kià Cananæan,

19 Hīmīsì Judas Iscariot kna lūtla lạkzūidis. 


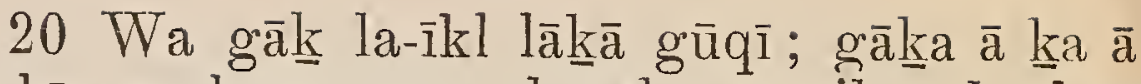
sa kīnum bagwānum kরāpīkū nāqil ìtīda, kās kìyosītl lā qīh-īdaās humh-īdā.

21 Wa gil mī sī glīglaglaules la knālā knīk, lāh dāknwa ās kās lī dāh-īda îks-duk: kākns nīk dā Ǩwa ì nūtlumātlī lā.

22 Gla wī da scribes yik̄a gākni geh-îd lāk Jerusalem nīkia, uknnūgwāda zū ǩ wās Beelzebub, hīmīsì gīikumāya sa devils lāwelā masītl tsū kwā kī da devils.

23 La klīiālāh dāknwuk kā gāk dāk la nīk lāh dāk ìd̄ zau lākn̄ Satan qīiā-masuk Satan ?

24 Glū kū gil um lāk qilyākaula lākni da numskumāq lìlqilāklāya, kīyos lāk tā qīhìdaās lāks u-līs lāk.

25 Glū kū qilyākaula lāk̄i da numskums

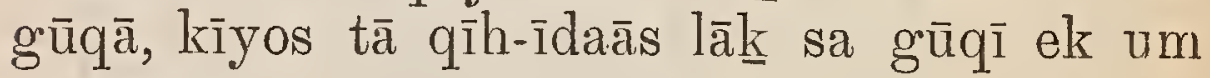
g'ūg'wīsā.

26 G Ğlù kū gil um lākni Satan nīk kās hekaulī qilyākaula, glū kās mātlzātlī, kīyos tā qīhìdaās lākns u-līsā, au um glātl là lāk kìyohwīda.

27 Kīyos um k ka à wīs numūq bagwānum qa-īglas nūq lāk gūqā sī da tloqīmasì bagwānumā, kās tlīnum-īk māmīkias as, hī-ga um kū la mā wīs glā lāk yitl-īd ka tloqìmas bagwānum, lā lāk wis gị thīnum-îlelāk gūqas.

28 đT Aula kias tin nīkiūkl, nāhwā um lāk̂i yekīnāyì dīgiklilū tsū-kl ]āk̂ sāsum as 
bag̣wānum ì, gla wa nāhwā yăkssum wătldumh

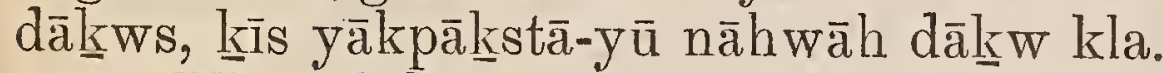

29 Wa yiglāk ungwā lāk yākpāknstā lāk k kà Holy Spirit, kīs klī dìgikli-

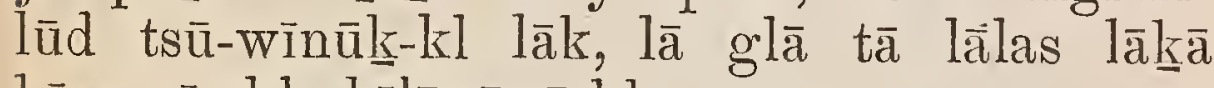
hīmunīs kla k̦īlāgāyū-kl.

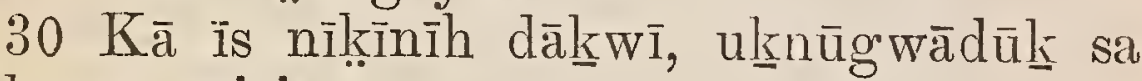
yāksamī spirit.

31 đ Hì mìs gāk k-âts abumpas gla wīs nātl-numwiyūt, glăh glosa, yālākum nūq lāk, kā klīlālāk.

32 Lì da kīnum bagwānum l̦̣utsīstā lāk, lāh dāk̂kw nīk yik, dok, abās glū nātl-num-

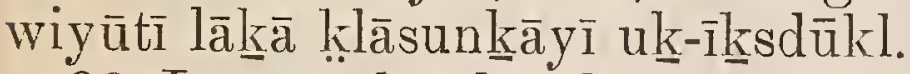

33 La nānākmīk nīkia, ungwā zin abumpà gla wun nātl-numwiyūtā.

34 La ās dūqil kund knā knwutsīstālek kās nīkī, dok, knun abump gla wun nātl-numwiyūt!

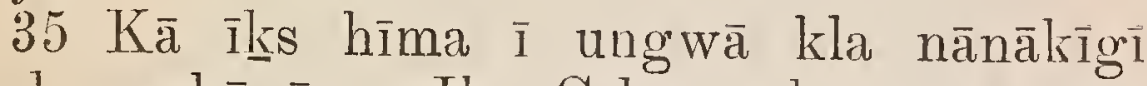
kluk naukāyā sa Ike Gīlkumì, hī mun numwiyūtī, glū wuḷwī, glū abumpì.

\section{CHAPTER IV.}

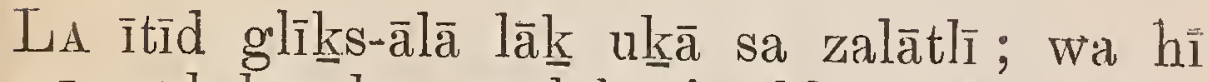

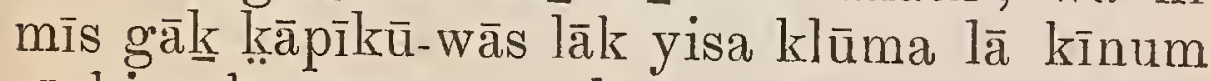
zì kias bağwānumā, lāgítl-ts au-um là lākss KWAGUTT. 


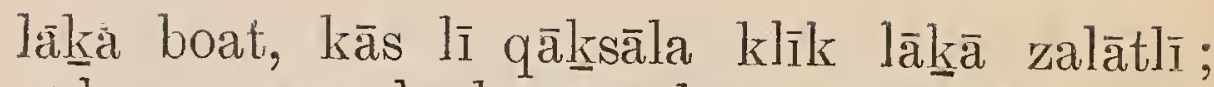
nāhwà mì sì da kīnum bagỡānum hĩ lì da klamā-ìsī.

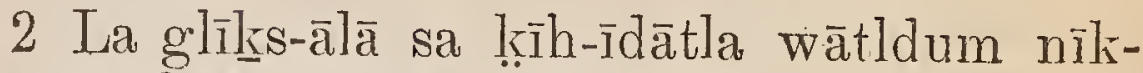
duma gīīa kāh dāknwī, nīkia,

3 Hūklī̄āla; dok, kni da zumīnū $\underline{k}$ là, kās le zumā:

4 Gil mīs gwìti-ālīsilas, la-āsĩ da wa-ūqī

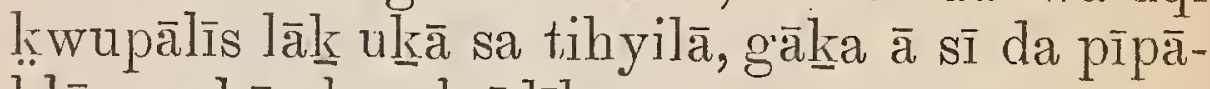
klūmas kāas humh-ìdīk.

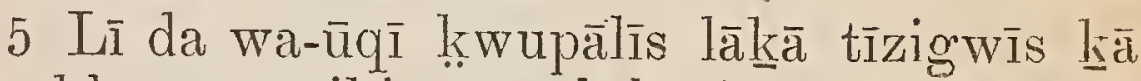
kīsī khāyātsa tịḳiā; wa hīh-īdā mīs lịwā kī lịizināyas wunkīsĩ da tị̣̂ā.

6 Gil mī sĩ da klīsila îkigìla, la-ās qumulh-

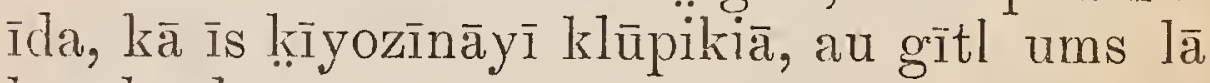
hwuls-ìd.

7 Lì da wa-ūq lkwupukā kīa kukunī, wa lì da kukunī lর̣wāk

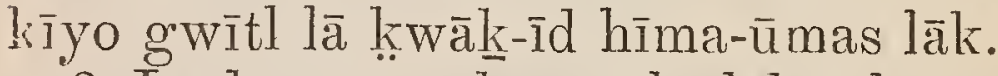

8 Lì da wa-ūq kw.

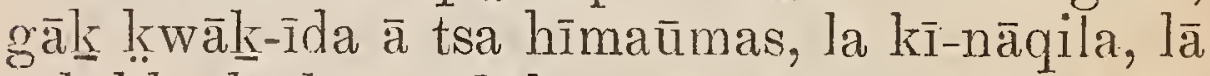
gịk-klaula knā yūdūhw sumgūstau punā, gla wa l̦uklaskum gūstau punā, gla wa lāḳinda punā lākīis wāk $\bar{a} \bar{a}-\bar{a} s$ dì.

9 Là vīkia, yilkē puspayū nūqā kās wuklilì, wìg à hyì hūklìà.

10 Gil mīs lā hīga-galīsā, la-ās wuklā sū sīs wa-ūgwīsī gla wa mālūgwagiyū lāk q⿳亠丷厂 ใ,ātla-āsā sīs nīkdumà gīlā $\overline{1}$.

11 La nīk lāh dāknwuk, la-um glā zawe 


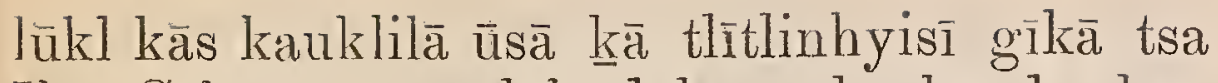
Ike Gìkumī: wa lāh dāknw glà kīi da knīsī uknnugwādis, nāhwā mīsik numāhyis-dumā

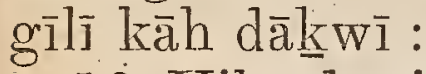

12 Yiks dūqilā-yū nūq ma ì kās dūqila-yū

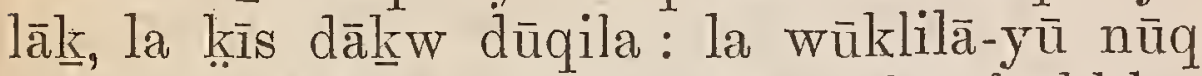

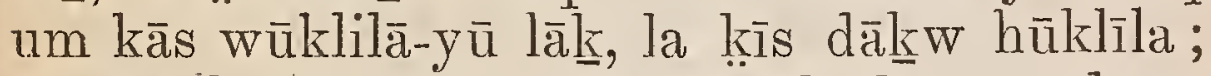
gwākutlāh dāknwā ì klāyū lāk kn kis qixdum,

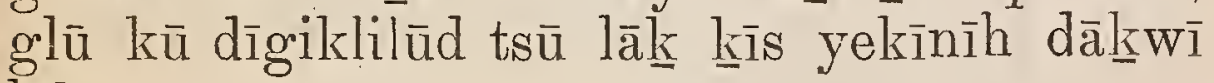
lāk.

13 La nīk lāh dāknwuk, k̦̣īsas āyūsilā kn̄kㅡ qībātla-as sāk sa? wa wīh-īda zau tā klas

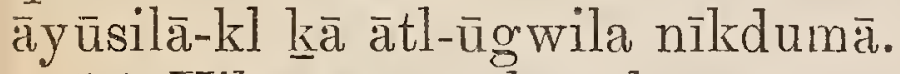

14. Yikāa zumīnūkwī hì um zumā sa watldumī.

15 Wa gāh dāknw mīs hī lì da tihyilā, yik

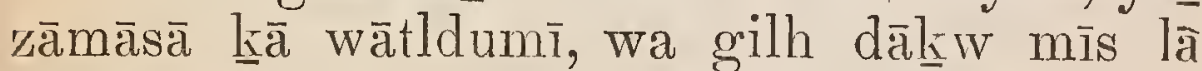

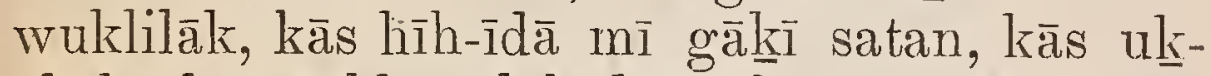
ìdì kī da wātldum lāh dì wāh zumzākum lāk naukīh dāknwās.

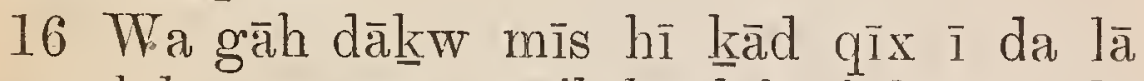

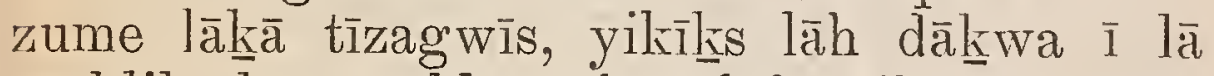

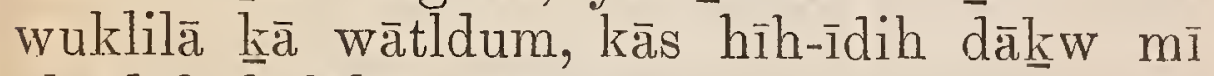
uk-ìduk dādālàk eḳīkulas :

17 Wa yih däkw kịks kīyosa ì klūpik lāk

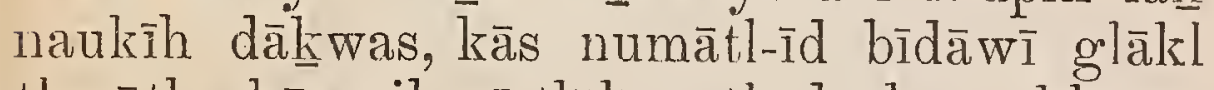
tloqātla, kāas gil mī tlālāwotl-īd glū mīklā sū kā $\overline{1}$ da wātldum, hīh-īdih dākw mìs yāh-ìda.

18 Wa hī mīs ātl-ūgwila yik̄a zumzāka lākēa

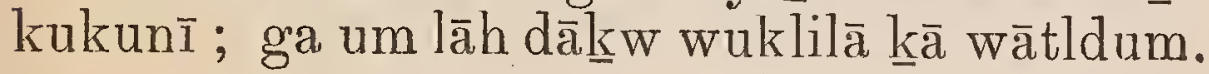


19 Lū̄ da nāhwāk awīlulkī lāk nāğwīsīk glū awīlulkulā kās k kīkiyādī, glū muhwile ḳ̌a nāhwā gāk gìgālīsil lāk naukīh dāknwas, tukiūd k kāa wătldum, kās kīyosī lā egāsā.

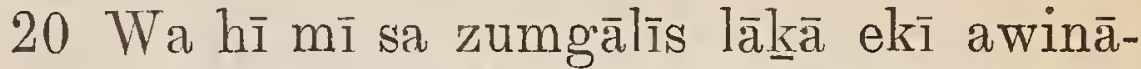

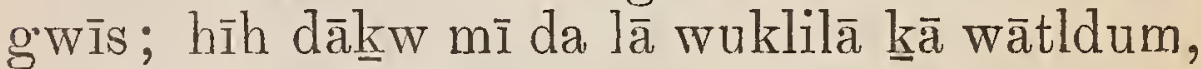
kās dādālik, lā knwāknā; yūdūhw sumgūstau punā, k़uklaskum gūstau punā, glū lāḳinda punā lākīis wākna-ās dì.

21 Là nīk dākwuk, hīmā gẩ da nīgwāzì kās aumī kupsumlìtlā sū-wā, glū

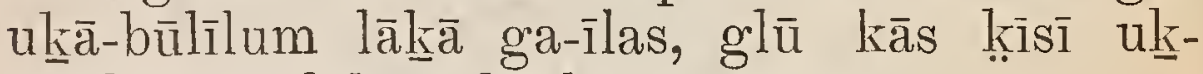
āklilūdāyū lāk̂īs ukzàtla-ās zīmäsa?

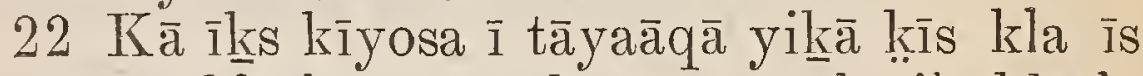
nītl-īdāyūkl, kīyos umka à wīs kwilā-klātla yikē kরīsālasī ìs lā khātlā.

23 Kū pusbāy $\bar{u}$ nūq lākni ung we bagwānum wìgā hyī hūklilīà.

24 La nīk lāh dāknwuk, yāklaula kā is

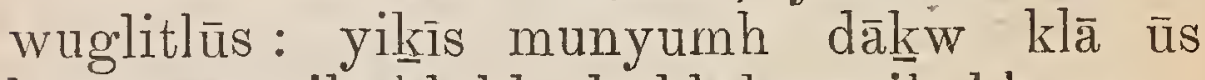

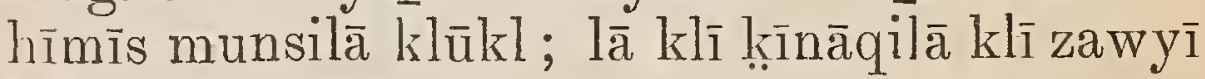
lūkl.

25 Yik̄i da uknnūgwād klā, hīmīs zaw sū klī, wa yiknì da ḳīs klā ulknūgwād-kl, hīmīs

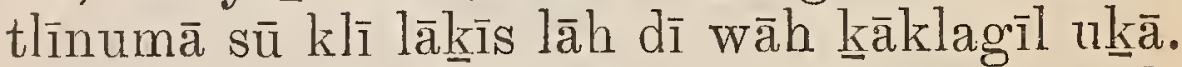
26 Lā nīkia, hīmīs gā $\underline{k}$ qīx $\overline{1}$ gīkāsā sa Ike Gīkumī, yi kss numāhyisa i gla wa bagwānum g wìtl-ālísilā sa zumza-īmas lākeā awīnāg wīs,

27 Lā mīknīkna knā kānūklī glū glāk-glā- 


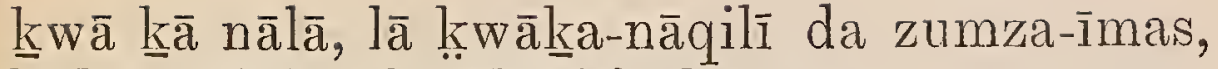
lā ḳis kneki]āk kwāk-joih dum as.

$28 \mathrm{~K} \bar{a}$ ūk da tikieks kwākā masa; au ma

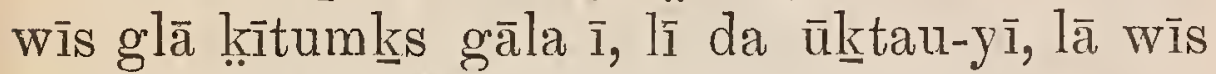
glì da zízidanū lāk̄ā ūktau-ȳ̄.

29 Wa gịl mīsī da zīzidanū lā klūpā, hīh-

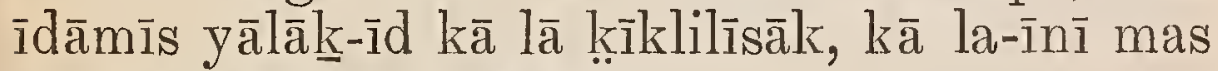
lastūd lāk humzunk-kāik.

30 Lā nīkiā, mā zints munyas klas gīlkāsāa sa Ilke Gìkumī, mā zints numāhyizās klā untsās?

31 Hī dā gōâk qīx ì da numskumstū bìđāwī

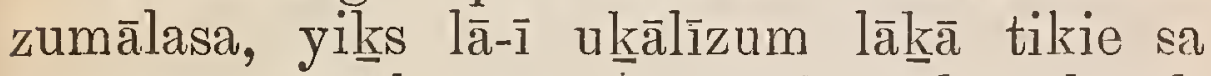
awīnāgwīs wāh ma ì umāyāki sūk nāhwāk zumālas ]āk wā nāhwāk awīnāgwīs :

32 Wa gil mīs glà zumgālīsā, kās lর̣wāk ìdī, kās lì wālazaki sūk nāhwāk ḳ̂ gilsgiltā-zìs klunākī, gāân mī sī da pīpāklūmasī quzuk-klāwīk.

33 Kīnumī sī da hī qețā nīlzdumā wātldums yiks lā $\overline{1}$ nīk sa wātldum ì lāh dāk k̂wuk, ]ākīis hîtl-āzūtl dāk k̂̄ kās āyūzitlā.

34 La kìs nīk sa wātldum ì yik̄̄ kìyosī nīkduma kāh dāknwi : la mīs glā a-ūqsīlāh-ìd kīis disciples ayūzūdisa nāhwā lāh dāknwuk.

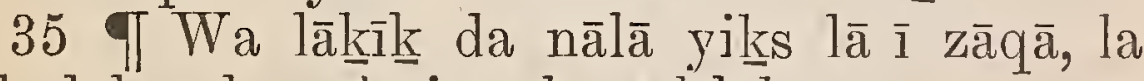
nīk dakzwuk, wīhyints lāwìtl lāk̄à upsūtī.

36 Gill mīs yālākīt kzā kīnum bagwānum,

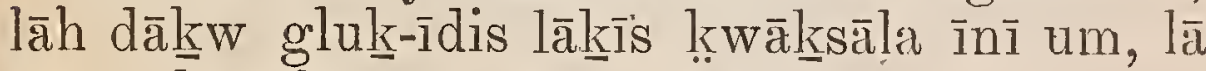
mī sī da ātl-ūgwila boat lā gola wī. 
37 La ās awìlāh-īdì da nāla, lì da kulāyī qutluk-sila kni da boat, lì da boat là kūtānāqila.

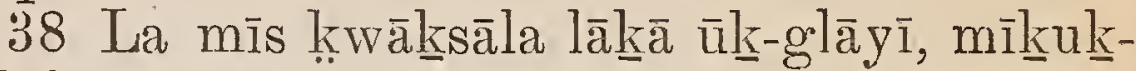
sal kulhw-sumī lkā kīnūtl: lāh dāk kw gwwīhìduk kās nīkīk, A.t, k़īsas awīlā-gīlā kuntsū tlìtlilāk ?

39 La às zih-ỉda, kās klūwilgātlī knā yaula,

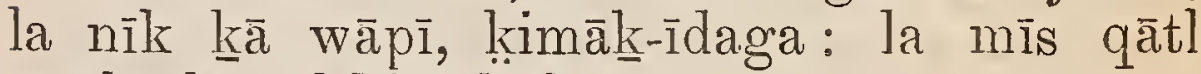
yaula, la aul kimākulā.

40 La nīk lāh dāknwuk, māzīs kitlìāh

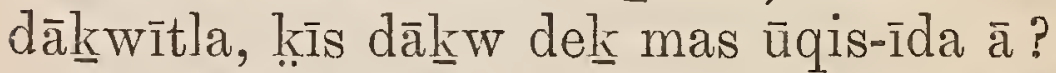

$4 \mathrm{~L}$ Lāh dākwa às aulā kial zindih-īda, la nīkiàya-pāla, māzau ānā wīsūk bag'wānum

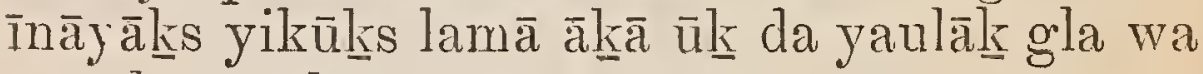
wāpī nānākìgī umq?

\section{CHAPTER V.}

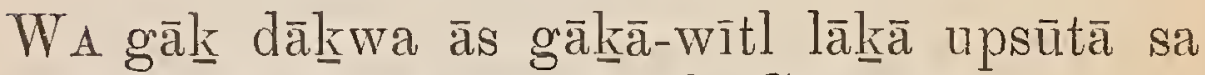
zalātl, lāk awīnāgwìisā sì da Gerasenes.

2 Gil mīs gāk wutl-tau lāknà boat, hīh-īdāmīs lā kākāyāla sū sa bagwānum gāyūtl zau-

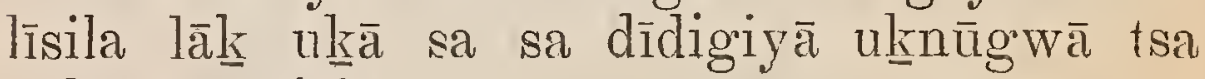
$y^{\bar{a} k s s a ̄ m i ̄ ~ s p i r i t, ~}$

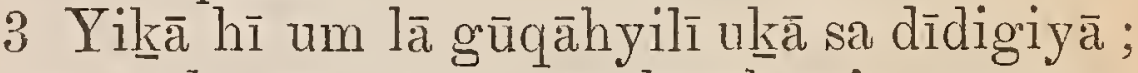
kīyos umkূa à wīs qayūghlāsuk yis numūqua bagwānum yitl-ịduk; yisa wậh mị kulkahyaul: 
4. Wāh nāhwā ma ì gwunh-īd tsū yiklīind tsū sa dunum $\overline{1}$ gla wa kulka-hyaula, au nāhwā mīsī da kullka-hyaula a-utlzā matsūs, gla wī da dunum wāh yiklidumk a-utlzā k kād, kīyos umka à wīs numūq bağwānum qīhidaas nūq naukumh-īdā masuk.

5 Hīmunātla mīsi knūk kākanūklī k gla wūk

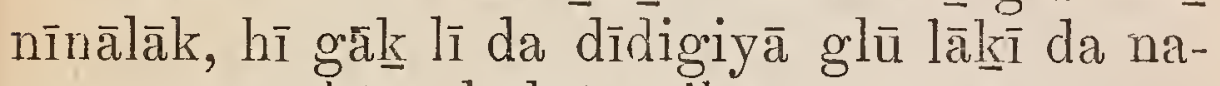
unge, qaqātl-tse, bukītā qilīx-um sa tīsum.

6 Gil mīs dūkn-wāklilāk Jesus lāk $\underline{a}$ qīsālā, la zilh-wīd kās umyāk-īdīk,

7 Lā qaqātl-tse hāsil, nīkia, mā zin klūs,

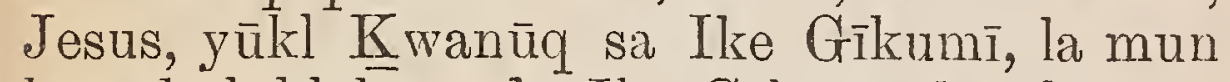

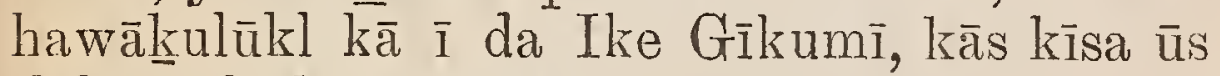
tlālāwūtl-īdā mas gā̌kun.

8 Kà nīkinnāyasīk, kīlaga yūkl yāksum spirit lāwe lākswā bag’wānumk.

9 La wuklāk, ungwā klās? la nīk yuk, hīmun glīkumī lūk-lūkwā; kā unūh wāk

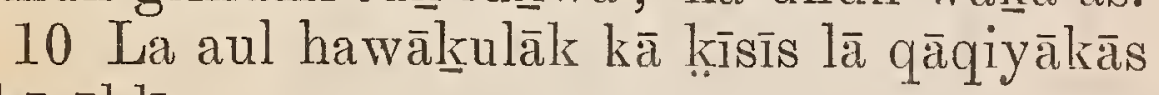
]̄̄

11 Là tā kīnumī da gæwasū hī gāḳ lì da nug’e hīmulā-gilìsā.

12 Lamīs nāhwā mī da devils hawākulīk, nīkia, lā lā hyinūh lākñ gowasū, kunūh lī lālākā lāk.

13 Jī Jesus hītlkāla umk: wa gākni da ya-

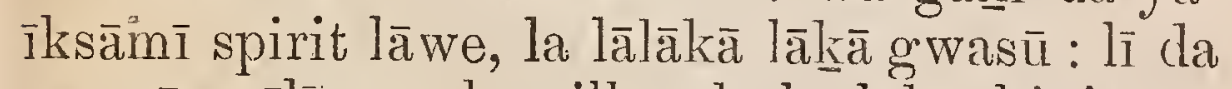

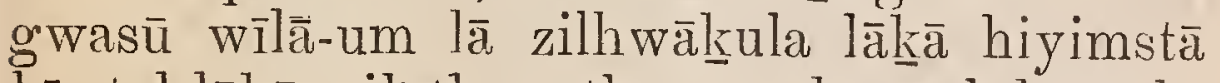

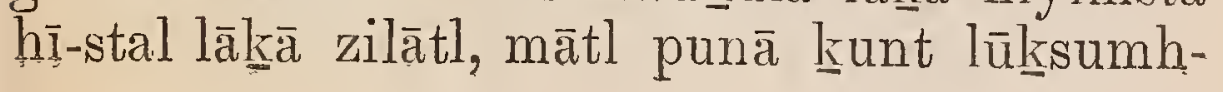


ìdis wākna-ās, lamīs wīla um wīhyinālīsum lākêa zilātlī.

14 Wa yih dāknw kñ da aāknsīiāh dek, lāh dāknw zilh-wìd hītl-tsau, la zikiātlilas lāksā town gla wa hì gāâk lì da âklālālìs: wa gāk dāknwa ās kās gākēi dūqā kī da qīh-ìdaāsī.

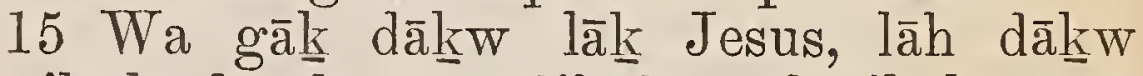
dūqilā kni da uknnūgwadih de sa devils knwaīsā, kū kzzawāqāa, glū ǩss la mā ì naukumh-īda, yaumk uknnūgwādihh-de sa lūkn-lūknwā; wa lāh dāknw zīndih-īdis.

16 Wa lì da dūqilek nìtlas lāh dāk̂kwuk qīhìdaāsā k kà uknnūgwādih de sī da devils, hīmīsì qīh-īdaāsā sī da grwasūh dì.

17 Lāh dāknw hawāknulāk kà lālāgīs qīd lāk awinnāgwīs dākzwas.

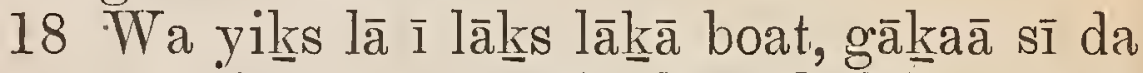
uknūgwädih-de sa devils hawăknuāk kās le kiāpin se lāk gla wì.

19 Kīs tā Jesus hītlkālāk, au um nīk yik, hāga nenāq lākīis nīnumūqa ùs, glū kās nītlā ùsā kì yis wālasī qīh-īdaātsa Ike Gīkumī kās, gla wìs lā-īnaja à wos-îdūs kās wăk k-îdi lūkl.

20 La mīs kās-īda, la zikiātlilas lāknā tītown wālasī qīh-īdaāts Jesus kāa $\bar{i}$, lì da nāhwā bagwānum knunyās-īdis.

21 đI Wa gill mīs lā ìtāwītlī Jesus lākēa

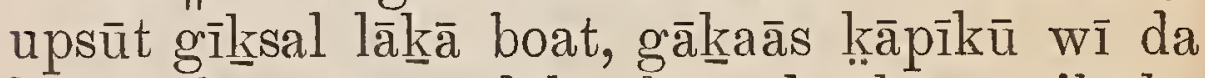
kīnum bagwānum lāk: hì tā lì uk kña sa zilātlī.

22 Gāknaà sī da numūqui gāyūtl lāk gīgi- 
kumāya sa synagogue, glīkādis Jairus; hīhìdà mīs humhw-wālīs lāk,

23 Aulākial hawāknulāk, nīkia, knun zidāk kwanūq la um lālaāla-gilìtlā, lamīsin hawākulūkl, kās gākna ūs wāk-ìd pāh-îd tsūs àyasau kūs lāk, kà qilā mī lākns.

24 Lamīsĩ Jesus gla wī; kīnum tī da bagwānum lāskumīk, lāh dāk knw tākiāpuk.

25 Numūq tì da zidāk, yiksā là mātl-unǩa giyū gwīl lāwela sū sa ulq⿳亠口冋,

26 Lāh da kīpun wütl-ım tlālāwūillilā matsū sa pīpatīnū $\bar{k}$, wūtl-um lā wìlā sīs dālāhdì, la hīwe kna ek-īda, au um glātl kzunglināqila.

27 Yikns la ì knālāk qịīlasas Jesus, gāâ lālākà kni da tākiāpīk lāk ulk uglàyas kās păgaakklilik qitlqeles :

28 Kā î̀ kss nīkia ì, kunklū au um lāk wāh um pāh-īduk qîtlqeles, lamīsin ek-īda umkl.

29 Wa hīh-īdā mīsī da gwakaulāh dek ulqā lā kiūtl-ìd, lamīs kauklātla umk lāknis

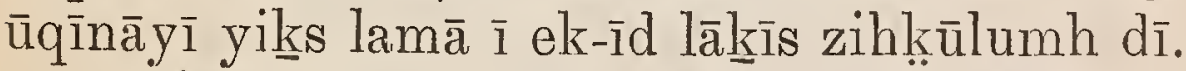

30 Li Jesus hīh-îda um wunātl āklilā k kā tlāhwāyi lāwe lāk, hyilpilīs lāk nukরakīin̄sā sì da kīnumī bagwānum, kās nīkī, ungwā zì da pāh-ìdek gin qîtlqelāg ?

31 Lì disciplesas nīk yik, dūqila ma ākūsā kwā kīnumk bagwānum tākiāpūkl, las nīkia, ungwī pāh-ìdì g'ākin?

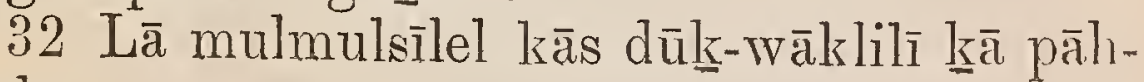
idek. 
33 Lā àsī da zidākī kitlilā, ek knwunāla, kauklilā um kīis lā-īnāyì ek-īda, gạ̄̂ humhwālīs lāk, kās nītlīk kīyos klīl kṇălā-yau.

34 Lā nīk yik, kzwanūq, la ums hītl-tsīstā matsū sīs ūqizālazī yūs: hìtlillk-îdaga, wìga ek-īd lākniss zih-knūlumh de ùs.

35 Wa yiǩs kīs ma i knwìtl-īda, gāk dāknwa $\bar{a}$ sì da geh-ìdī lāk g'ūqā sī da gîlkumāya sa synagogue yikz̄a nīkī, là um tlilīs knwanūqūs,

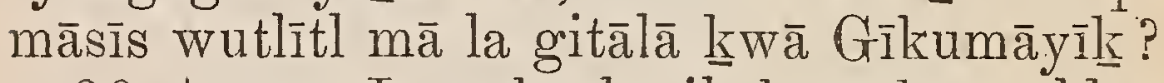

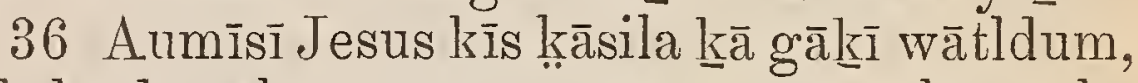
nīk kīi da gīkumāya sa synagogue, qālā nūtla, au umā ūqisulk.

37 La kīs hītlḳālāk ūgwile bagwānum lāskumīk, hīgamī Peter, glū James, hīmīsī John yik zāyes James.

38 Gāak dākn lāk gūqā sī da gìkumāya sa synagogue, la dūqila knā kīnum ḳwạ̄nwasaula.

39 Gil mis la-îklā, la nīk lāh dāknwuk,

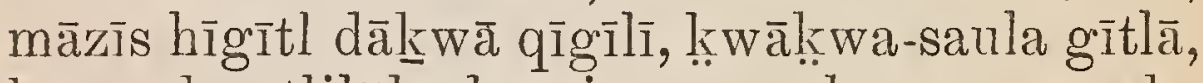

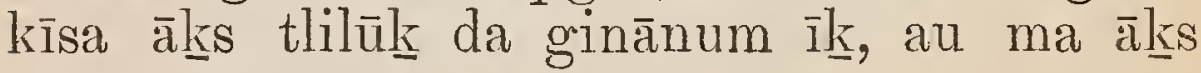
mīkā.

40 Lāh dāk wīlawilsā masuk, uk-îiduk ùmpa sī da ginānum glū abumpas, gla wīs wa-ūq maulā, kāss lì la-

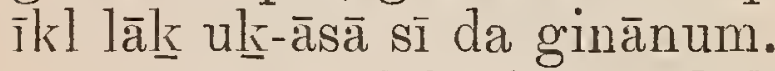

41 La às dābātlzānund kēà ginānum, kās nīkīk, Talitha cumi, yiknī da nīkiākss nīkīa ì, zạāạdākum, lạnụn nịikiūkl, glāknwīdaga. 


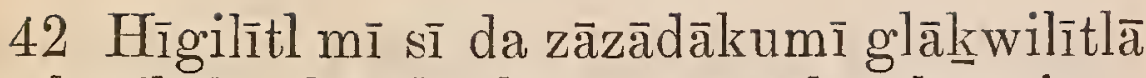

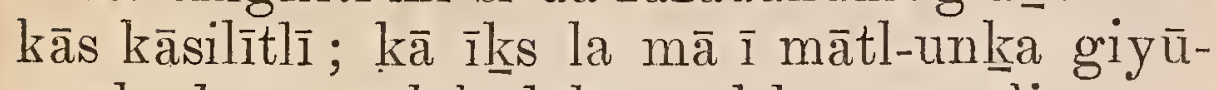
gwīlīs k̦wīsa : lāh dāk aul kunyās-ìdis.

43 Lā tloqal bulāh dālewwuk kā kíyosìs bagwānum kautl-āklìā lāk kīk, lā, wek̄̄a, kà zaw sū wìsī da ginānum, kàs humh-īd tsa wa.

\section{CHAPTER VI.}

W A lā bo sīk da, gākini lāknis husāk awīnāgwīs, lamīsī disciplesas lāskumīk.

2 Wa gil mīs lā sabbathā, lā glīk synagogue: lì da kīnum bagwānum yik̄

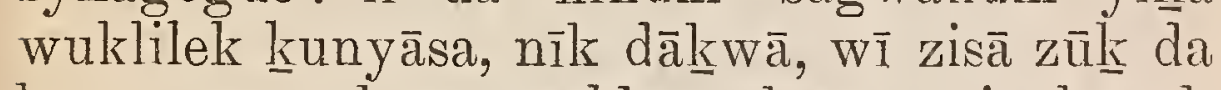

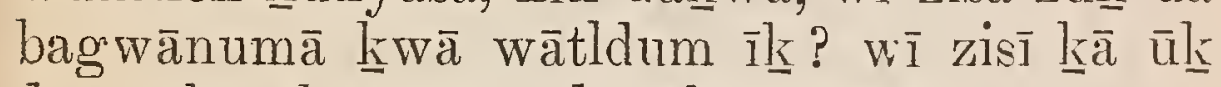
da naukāȳ̄ zaweq, glū $\bar{\imath} \bar{a} k \bar{\imath} \bar{l}-n \bar{u} q \bar{a}$ sa wunwunhyis $\bar{i} k$ qīgīla-tsūk àyāsauks ?

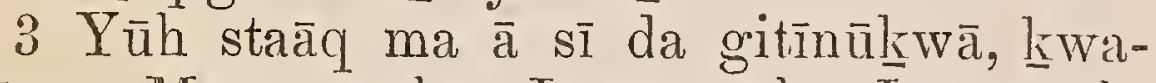
nūqas Mary, nūles James, glū Joses, glū Judas, hīmīsī Simon: kisa ì ka ūk y ū-um lūk wīwāḳ̂eks lūk glū wuntsā ? lāh dāk $\underline{k} w$ wānīkās.

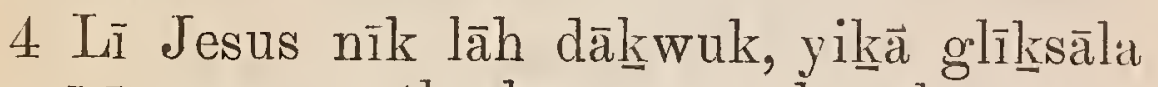
kīsa ì is māyā-untla, hīgama às husāk awīnāg'wīs, gla wīs glīglaglaula, kīs māy $\bar{a}-\bar{h} y i \bar{l} \bar{k}$.

5 Wa kīyos tā qìh-ìdaāts qīgìlas nūqs

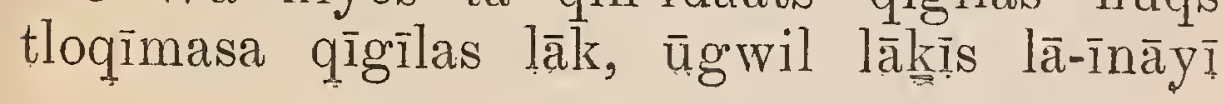




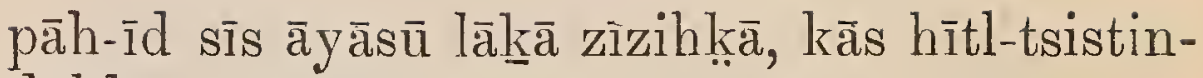
dālìk.

6 Lā knunyāsā sīkns kīs dāknwā ì ūqisa: lā

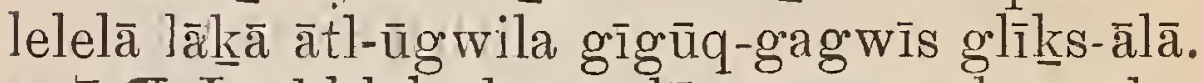

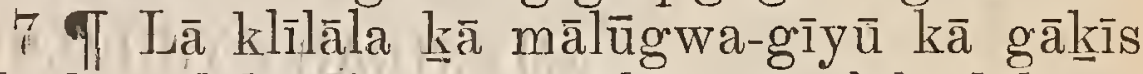

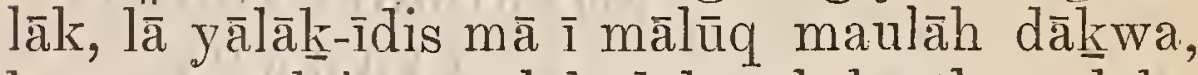

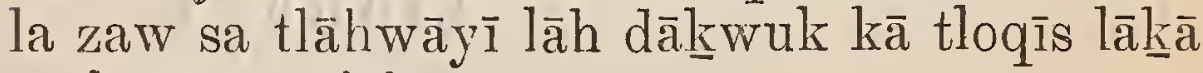
yaīksāmīs spirits.

8 La nīk kà kīs dākwīs da-āq nūq lākīs lāīnīh dāknwī, kā hīgāmī sī sị র̦iākānau, kīyosīs giwilqs, kīyosīs dāla gìzauk wusīgānūh dākwas :

9 Kā tītupsīsilā mī glas, glū kả kìsīs mātlī k़ūkzauyas.

10 La um kna à wìs nīk lāh dāknwuk, lāknīs nāhwā klā ūs ȳūq la-īglas, hīk se umkl wīsis lì kīs mì klà kūs klìqilīs-kl.

11 Wa kīi da awīnāgwì-zīnī klasa, kīs kla ek-āk klūkl glū kīs wuklilā klūkl, yikss le klā kūs klīk-wìdikl, kitlūdā kīs tītih-sīzīh dākwūs kā $\overline{1}$ ka māmātltīki kāh dāknwi .

12 Lāh dāknw mīs la glīksāl kā māyātīs nāhwā bagwānum.

13 Lāh dāknw lāwūdāla knā zīzāhkūlurn, glū gwakuk klīlābund tșa klīna lāks kīnum zìzihk $\bar{a}$, lā ek-ìdā masuk.

14 Lī king Herod khālāk, kā glīkuma sīkns la $\overline{1}$ kaḳātlaulayau, la wütl-um nīkia, la um kuntī John kī da Baptist de qilāh-īda, hīmīs lāgîtl tsa tloqīmas qīgīlas gāk nītlā lākī. 
15 Lā glā tī da wa-ūq nıkia, yū um Elijū, lì da wa-ūq nìkia prophetī, hīh sta àqa ì gāyā kī da prophets wūtla.

16 Là glā tī Herod nīkia yilzs la ì khālā, hī um Johnī, kun kāh-ìd tsa wūtla; la mì qilāgilīsa.

17 Kā Herod tākss yālākā ūtl kā dāh-īduk John, lūtlī wulgā-lìtlāk, kā Herodias kunumh des zāye sī Philip, kākss lā ì kugādih-īdis.

18 Kā John àks nīkia ūt]āk Herod, kīsa à kūs ekikss la à kūs kugād tsūk kunum ākns zāye.

19 Hīmīs lāgītl tsī Herodias yāksamīs naukāyāk, nīk kā tliles, kīyos tā qayūlqīiātsīk.

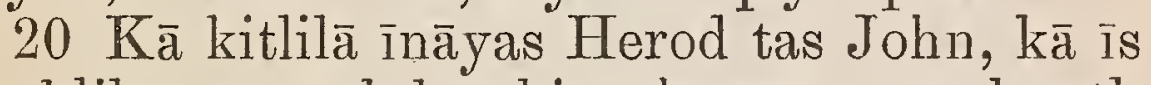
kauklila īnī mā kīkss ekia ì bagwānumā lāgītlts māyāhyilāk; gill nāhwā ma ùtl wuklilāk,

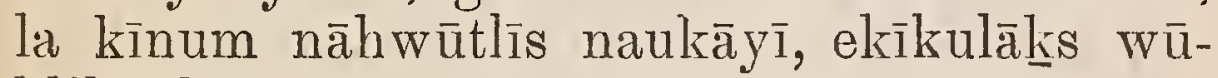
klila āk.

21 Wa lākeā numkssa nālā, la à sī Herod lâkīs māyūglumh dum ùti nāla, ḳwīlas lk̄à gīgikumāyī glū gìgikumāya sa soldiers ğla wa nīnauksaula bībag̣wānums Galilee.

22 Gil mī sa zāzādākum yik kwanūqas

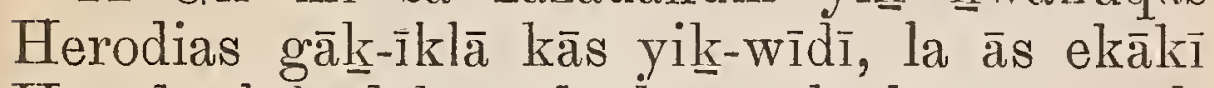
Herod glūh dākwī da ḳwazitlī humūt-ts, lī

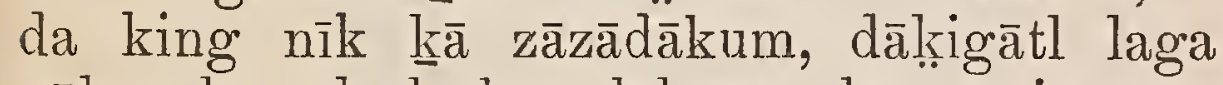

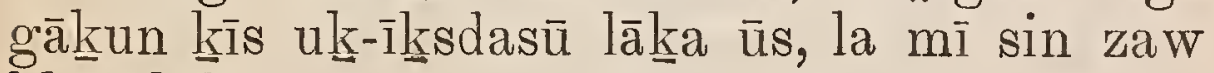
klasis lūkl.

23 Lamīs aul tloqāl nīk yuk, knīs qayū kla 
ūs k̄às uk-kiālasū wūs gākun, lamĩsin zaw

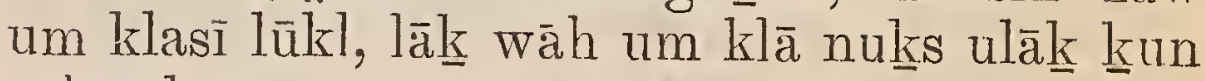
ğīkāsīln.

24 La lāwils kās nīkī kīs abump, māsin dāạ̦iāla sū kla, la nīk yuk, hyūmsas John kā Baptist.

25 Hīh-īdà mīsĩ da zāzādākum gā̄ hānāqil lāk kà king, kās uk-lরigātlīk, nīkia, hīmun qayù kās hīh-īdà mūs zàve gāknu gīzau lāk kulqe ì hyūmsas John kīa Baptist.

26 La āsī da king aul māyātā; wa kāg̣līs

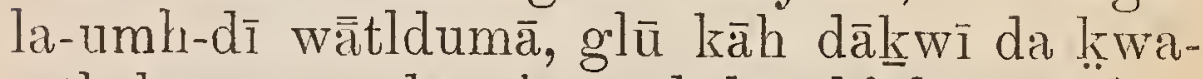
zìtlī humūt-ts, kīsittl-ts nīk kās klālīqīgāyīk.

27 Hīh-ĩd gītl masì da king yâlāk-ìd tsa

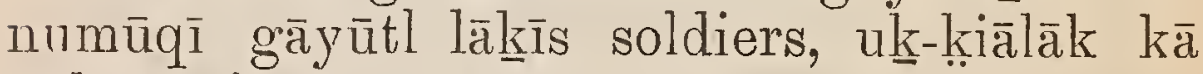
gā̄kī sīs hyūms as;

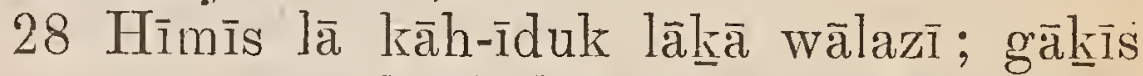

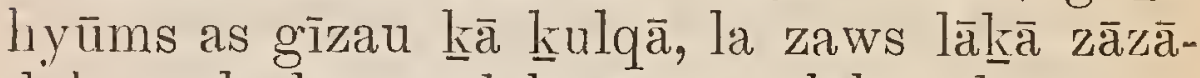
dākum, lì da zāzāiākum zaws lākēis abump.

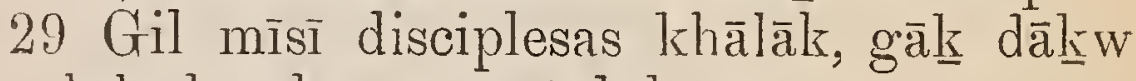
uk-ìduk, lkàs lì wunumtiduk.

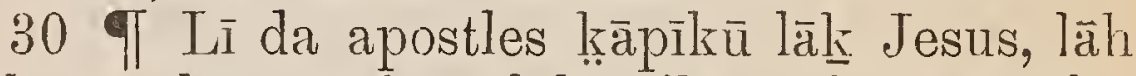

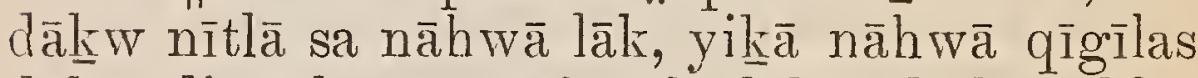

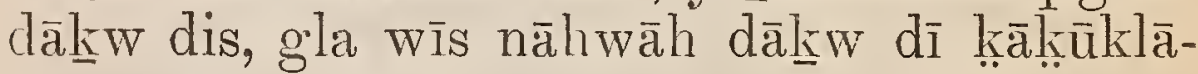
mazumā.

31 La nīk lāh dāknwuk, kīlaga umas-gl

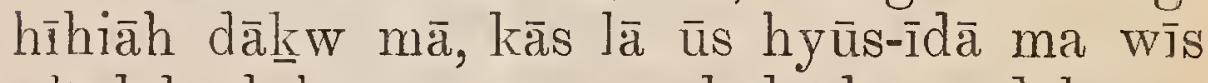

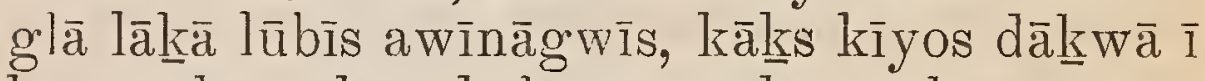
la qāqīkumālas ek humāpa, kā wāka $\bar{a}$ sā sī da au-um klāklāyū-wīstàla lāk. 
32 Lāh dāknw gluk-īd boat sinā, lā lāk lūbīs awīnāgwīs hīhia ma.

33 Lì da bībagwānum dūqilà kịks lāh dāknwa ì, lamīs kīnumī da mātl-telek, lāh dāknwa às yāyin kakāsduk, lālā̄ lāk geh-īd

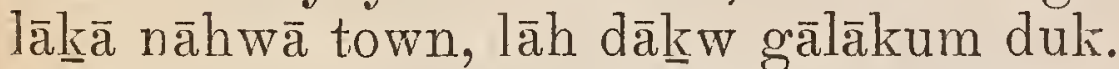

34 Gil mīsī Jesus lotl-tau la dūknwāklila kầ kīnum bagwānum, la wosis, kà hī-īnīh

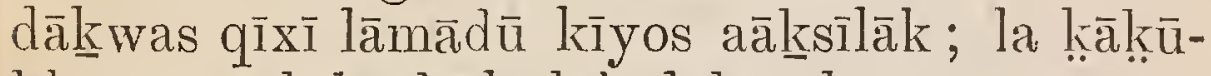
kłā matsá kị̄h-īdātla lāh dāknwuk.

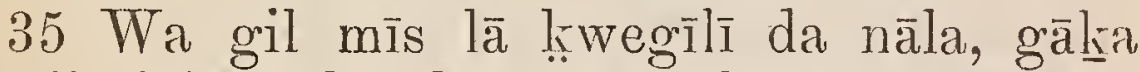
āsĩ disciplesas lāk kās nīkīk, lūbīsū $\underline{k}$ da awī-

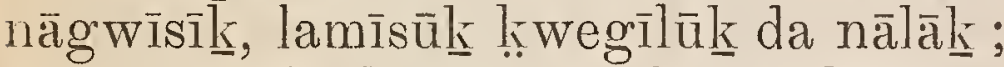

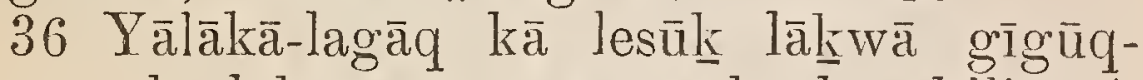

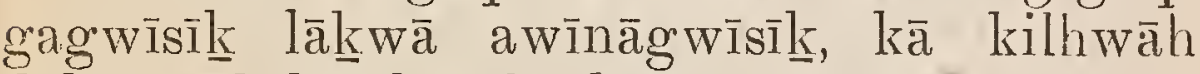
dàkwī sūk kās humb-ìd tsa wa.

37 Aumìs nānākemī nīk lāh dāk

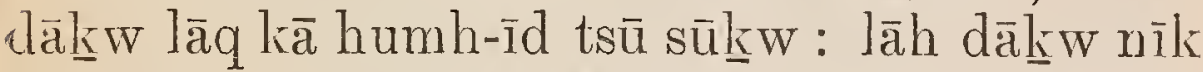
yik, lāle hyūsunūh kilhwās mātl punyāge dālä lāk lịwākwuhsumā kunūh zaweq kā humb-īd tsū sūk $\underline{\text { w }}$ ?

38 La nīk lāh dāknwuk, gintsumūs qinīqà kūs? hās dūk-wīiduk: wa gilh dāknw mìs kautl-āklila lāh dāk $w$ nīkia, sikịia skumk, gamīs grāda mātlik kiuütilā.

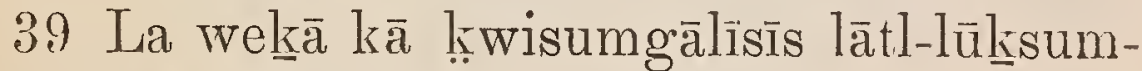
līsīs lāk kà kịdagwīs.

40 Lāh dāknw knwisālīsa, àtl-ūgwakīsa, laīlākinindā gla wa sī-sịḳiā skum gūstawīs oknwaIras.

41 La ukk-ìd knā silḳiā skum qinīqā gla wì 
da mātlī kniūtilā, la îḳiakumh-īd dūkūstaula

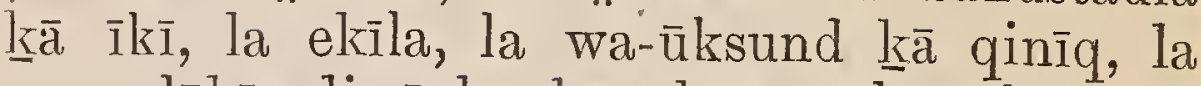
zaws lākīis discīples kā ukum-gālīsīs lāk, gla wī da mātl ḳiūtila gwītl-ālīsas lāknā la knwizīs.

42 Nāhwāh dāk k wis humh-īda, la nāhwā um pūtl-ī̀la.

43 Lāh dāknw kupī-gilīisā knā wākīsāwāyì,

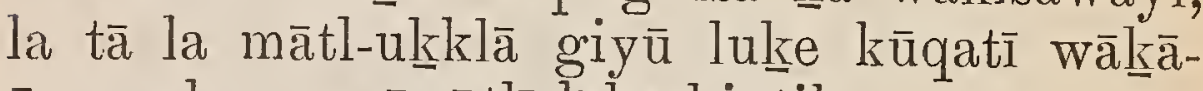

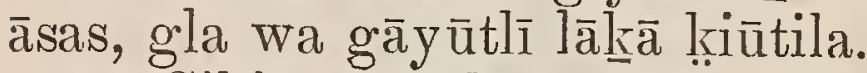

44 Sikniā punā kuntā lūk̂́sumh-īdī wākna-āsa sī dà bagwānum humh-īd ǩā qinīq dī.

45 T $\mathrm{Wa}$ hīh-īdā mīs tloqăla kīis disciples

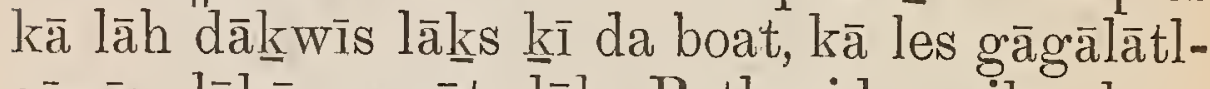

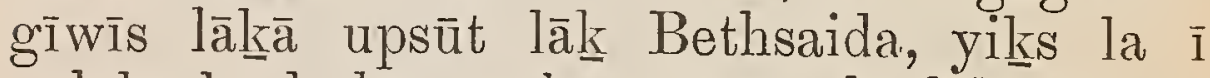
yālākā kñ da kīnum bagwānum kā lālāgīs.

46 Wä yikzs la ì qātl hulākias-kākn, la kāsìd qāqiyākā lākna nuge kās le hawākn-ula.

47 Wa gil mīs zãq àa la um nakauklāyĩ da

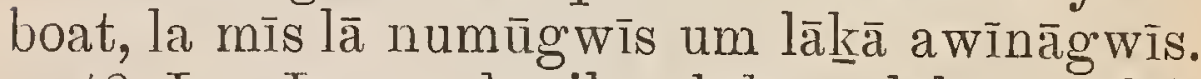

48 Lì Jesus dūqilā kīkns tlāhwumālāh

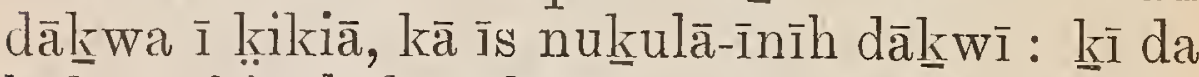

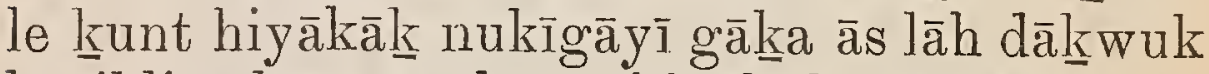
kāzikliyi lkā wāp, lamīs hiyākulā lāknsduk.

49 Wa gilh dā

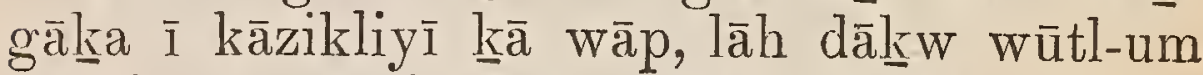

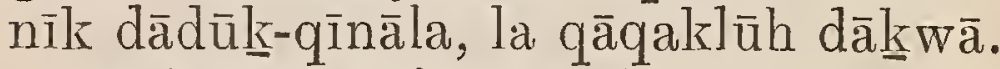

$50 \mathrm{~K} \bar{a}$ ìs nāhwā ìn̄h dāk um um dūqilāk,

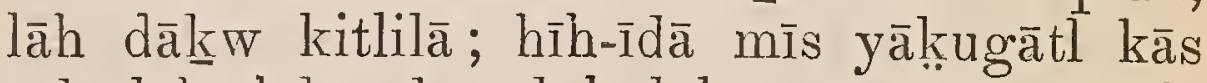
nīkī lāh dākswuk; elরīikulāla, nūgwa-um, qālā kitlil. 
51 La mīs lākns lāh dāknwuk, lī da yaula

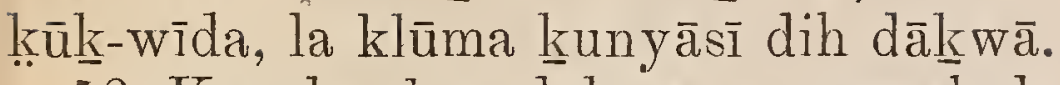

$52 \mathrm{Ka} \bar{a}$ iks kīs dāknwā $\overline{1}$ gīga-īkulā qīhìdaāsā kā qinīq dī, kā pīse sīs nīnaukīh dā $\underline{k} w \bar{i}$.

53 Wa gilh dākzw mīs lā-wītlā, gāâk dāknw

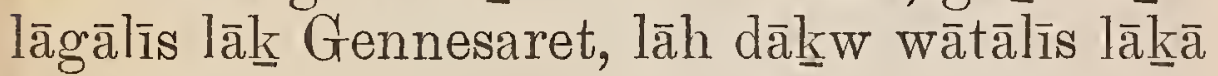
a wīnāgwīs.

54 Gilh dākw mīs lotl-tau lāknā boat, hīhìdāmīsa līlqilāklayī mātl-tīgaā klilāk.

55 La zīzālā-hwīlelāh-īd lāknā nāhwā awī-

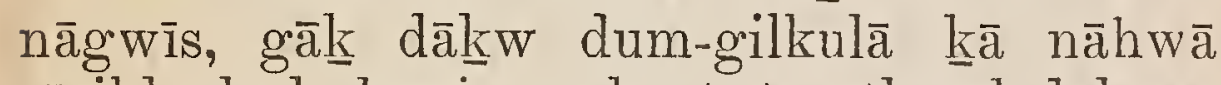

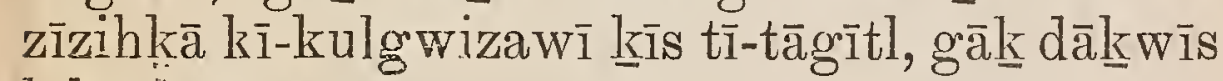
lāk uk-āsas.

56 Wa lāk nāhwā la-āts lāḳa nāhwā town gla wa nāhwā awīnāgwìsa, lāh dāknw kulqumgā-ulsilā sīs zīzihḳạa lākēà kāyāsī, lāh dāknw

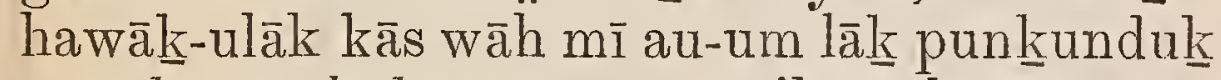
īwunk̄āyas kūkzzauyas, wa yik wākaās mā sī da lā pāga-ăklìiāk hī mīs lā ek-îdì.

\section{CHAPTER VII.}

WA gāknaā sa Pharisees ḳāpīkū lāk, gla wa

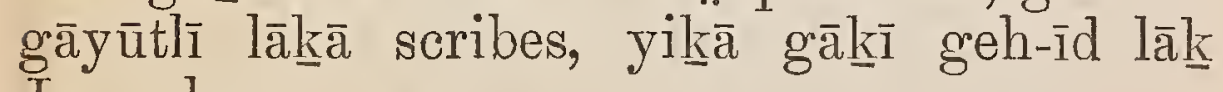
Jerusalem.

2 Lamīs dūqilāh dāknw knā gāyūtlī lāk disciplesā sīks kīsa ì zunzungiqulks la $\bar{i}$ humāpā, lāh dāknw nīk kīkss mū-uimknwulā ì.

KWAGUTL. 
3 Kā . ì da Pharisees glū nāhwì da Jews sāks ātl-ma ì hrmh-īdukss lā ì zunzunh-wìda,

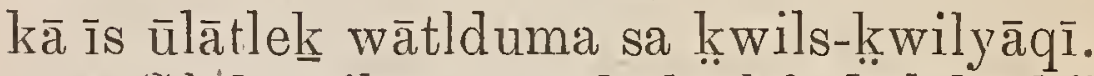

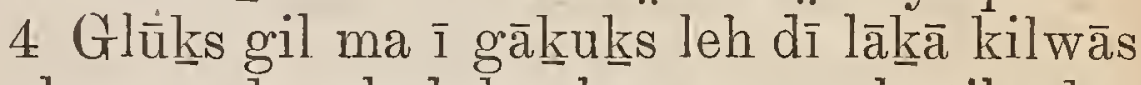
lā kīsa ì humhīdukss kīs ma ì lastih-īda: hīmīsa kīnum ì ātl-ūgwilā qīgīlas, yịk lāh dāknwi uǩ-ìd tsūs kās a-ulgīlâ sūh dāknwā, yikīik da zūkwek ḳwī-ḳwāstā glū hun-unh-

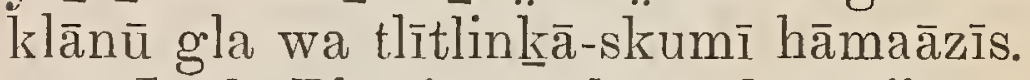

5 Lì da Pharisees gla wì da scribes wuklāk, māzì kīsīt]̄à sūs disciplesā kūs nukutl-tawek wātlduma sa ḳ़ils-ḳwilyāq wūtla, humāpa ākss kīs ma īk zunzunhwìda.

6 La nānākn̄i nīk lāh dāknwuk, nukautl wìs tī Isaiah yiks lā ūtl wātldum nūqūs yūkl klīhklakwis, lāk kịiāâtla in̄i mas, yikwā lìlqilāklāȳị māyānāla gāknun kla sūs sumsīk, lā glà tūk nì-naukāyākss qīsātla gāanun.

7 La kīyos qaȳu sūk umy āki-ināyākns gāknun, ḳāḳūklā mazum nūqs wātldumas bagwānum kāla-um.

8 Lāh dāk kwa ākūs kịiakāk wātldumas God, kās lā ùs kātlāk wātldumas bagwānum.

9 La nīk ]āh dāknwuk, aula ākūs qīstā masuk wātldumas God, kās lāh dāknwa ùs àkīla k̂īs hūs dākw mūs wātldumā.

10 Kà Moses ākns nīkia ūtla, māyāhyilā lāk ausī glū abāsin, wa yikī da yeḳiàla kla knīs ūmpì glū lākīis abumpì wìgā hyì tlilā.

11 Là glā tas nīk dākwă, gil mī klī 
numūqī bagwānum nīk kīis ūmpī glū lākēis abumpī, lī da zawe lākssde un klūkl Corbanā, zawek God yik̄ā nīkiākss nīkia ì.

12 Lāh dāknwus la hìtl-knāla umk knīs là

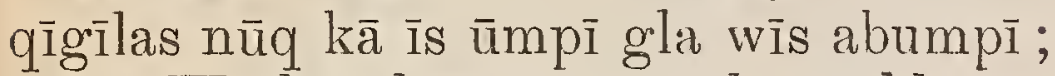

13 Wātlwātl-tsīstā misuk wātldumas God yisūs hūs dāknwā kūs wātlduma, yikūs le kūs i-kzāya: gla wī da kīnum ūs hī qīx qīgīlasa.

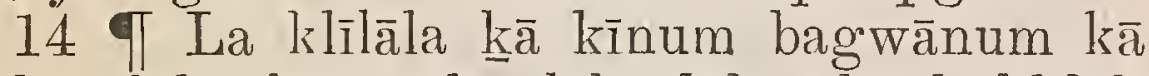
gākēis lāk, kās nīkī lāh dāknwuk, hūklīlāh dāknw las gāknın, glū kās āyūsatla ūs :

I5 Kīyos lākī da nāhwā humes bagwanum

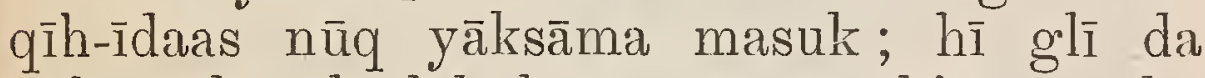
nāhwā lāwela lāk bağwanum yākiā mas k kāa bag'wanum.

$16 \mathrm{~K} \bar{u}$ puspayū nūq lāk $\bar{i}$ ungwe bagwanum kās wuklì̄a-yau, wīga hȳi wuklīā.

17 Gil mīs la-īkl lākēa gūq bo sa kīnum bagwanum lī disciplesas wuklāk lāk qībātla asas wātldumas.

18 La mīs nīk lāh dāknwuk ūgwākāh dāk w mas kīs āyūsila à? kīs dāknwas dūqila kīkss

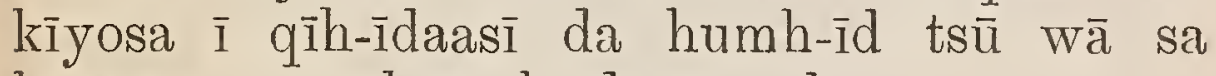
bagwanum yāksumh ìdā masuk ;

19 Kā kīzinnāyas ] $\bar{a}$ lāk naukayas, he àsì tuḳes la-āts, kās le lāwe lāḳā l̦̣igāzì?

20 La nìkia, yik̄i da lāwela lāk bagwānum, hī um yākī̄ mas k kà bagwanum.

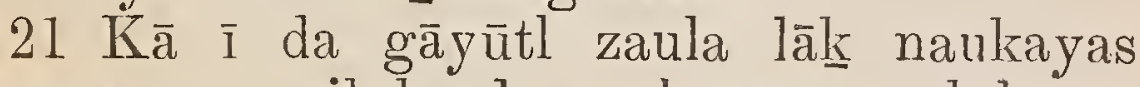
bagwanum, yikīị da yāksamī nīnșīkayā, 
autlīdālazī, gilūklīgwālazī, klīklisbazālazī, wunwakaula innayī,

22 Awillর̣azālazī, mīmtl-bazālazi, klīḳwizālazī, klauzălazì, yaksamī dūqătla īnī, yākpāksstālazī, klumkā $\overline{1}, n \bar{u} t] \bar{a} \bar{i}$ :

23 Ges tā um gāda nāhwā yāgālazì gāyūtl

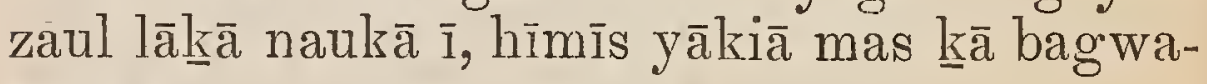
num $\overline{\mathrm{i}}$.

24 đI Hīmīs geh-ĩda ăts, kās le lāk uk unās Tyre glū Sidon; lā la-īkl lākēa gūq, kīs tā hītl-kāla wāh kauglitl-ts numūqa bagwanum: kīyos tā qīh-īda-āts k kwilā-klātla.

25 Kà ì da numūqĩ zid̄ak, yikā knwungwāde sa zāzâdākumī yiknā uḳuūgwāde sa yāksamī ziblụūlum, lā ì lর̣ālāk gāk lāk kās hum-hwālìtlī lāk gūgwayaus.

26 Greek tī da zidāk, Syrophenician $\overline{1}$ qaīnūk dumas, lamīs hawāknulāk kà qìdāmasī sī knā zihḳūlum lāk k kwanūqas.

27 Lì Jesus nīk yik, hī umas glī da sāsum

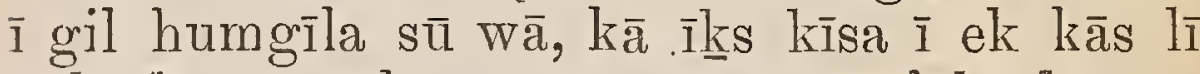
zuk-īdāyū wī humāya sa sāsum ì lākn̄i da waūzī.

28 A umīs nīkī da zidākī lāk, kegl Gīkumī; lamīs glī da wa-ūzì lāk awābolītlā sa humhdumītl humāp umk hā-umūtā sa sāsum ì.

29 La nīk ks̄a zidāk, hāga; kā. ūs le kūs wätlduma, lamī da zihḳūlum lāwe lākn̄is knwanūqa ūs.

$30 \mathrm{Wa}$ lamīs nenāq lākeīs gūq, la dūqilā 
knis knwanūq ek-um lā qilzaulītl knā tāgītl, laum lāwe da zihḳnūlum lāk.

31 Tा Lamīs bos awīnāgwīsas Tyre, gāk lāhsau lāk Sidon kās gā̄n̄i lāk zilātlas Galilee, gehsaụ lākea nākāwălīsas īwunkeīlīsas Decapolis.

32 Gāk dāknwi sa numūqī gwulqum lāk, yịkà kīsā knād hīlāla yāḳuntāla; lāh dā knw

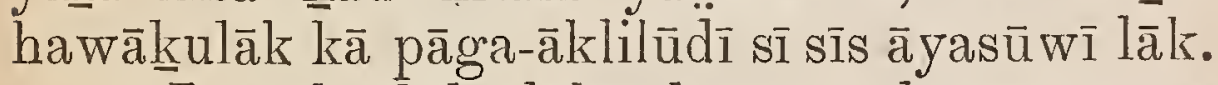
33 La ukn-īduk ]āknā kīnumī bagwānumā kās hīgā-īs mī, la zimzūduk puspāyaus, lā kna à qīs-zanunda kās pāh-īdì k kilumas ;

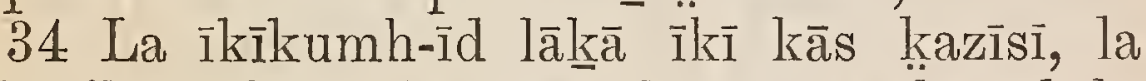
nīk yik, Ephphatha, kzâ nīkī, wīga uksstūduks.

35 Lì puspayaus uk̂sstü-hwìda, la țingiklìì kxilumas, la helālāh-īd yāaknuntāla.

36 Lamīs bulāh dāknwuk kā kīyos dāknwīs nītlā sūs lāk̂ numūqā bagwānuma : auh dā mīs klūmāh-īd la zāzākẹiālāh-īdis ;

37 Lāh dāknw àula knunyāsas, nīkia, kìyos

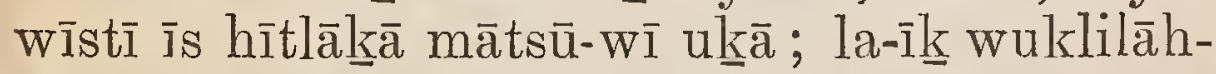
ìdā mas knwā kīs dīk wuklilā, gla wa kīs dīk yāḳuntāl la yạ̄̂nugātla matsū sūḳ.

\section{CHAPTER VIII.}

WE lā kna à îtīd gāk kīnumī da bagwānum, lāh dāknw kìyos humes, lì Jesus klīlāla kīis disciples ka ga âkīis lāk, la nīk lāh dāknwuk, 
2 Wosun kla sa kīnumk bagwānumā, kā ūs la-īnāyīk yūduh pun hwās kāpinh-se gla wun, kīyos hurnāya:

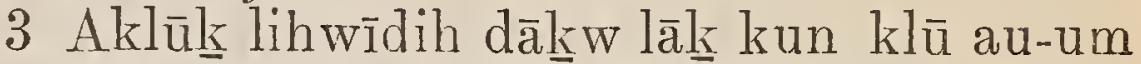
lāk yālāk-īda lāk kuq kà le sūk nenāq dāknw

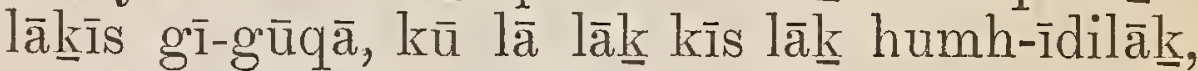
kā īks qīsāla ì geh-īda āsā sa wa-ūqīk

4 Lì disciplesas nīk yuk, wīzisā zau tā klintsāk hịtl-āla lāknā lāq làk knwā lūbīsīk awīnāg'wīsā ?

5 La wuklāk, gintsum ùs qinīq dāknwā kūs? lāh dāknw nīk yuk, uglabū skumk.

6 La ukkiagātl kā qusum-gālīsì sa kīnum

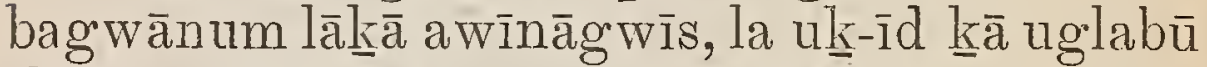
skum qinīq kās mūmul kigâtlīi, la wa-ūqs unduk, kās zawes lākīis disciples, kā zawes sìts lāh dāknwuk, lāh dāknw uknumlīsas lāknā kīnum bagwānum.

7 Lāh dāk

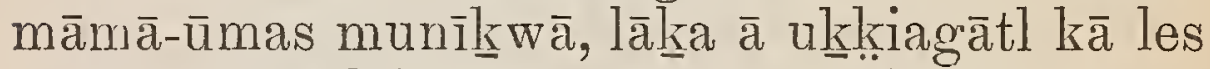
uk kum-lizum lāh dāknwuk, lā ì qātl ekìlāk.

8 Lāh dāk hw humh-îda, la pūtl-īda: lāh

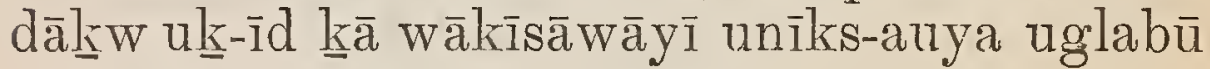
wīk klā tā lā la-ulksi kūquatā.

$9 \mathrm{M} \bar{u}$ puna knuntā lū ǩsumh-īdì wākna-ā sa sĩ da bagwanum: la yālāke-îdis ka lālāgīis.

10 Hlìh-īdā mīs la lākss lākē boat gla wīs disciples, kās gāḳi lākna awīnāgwīsas Dalmanutha.

11 Gāk dāk knwi da Pharisees, lāh dāknw 
sa wākīsäwīh de kīis lā yūs ukn-īd tsa wa? lāh dāk nwìk yuk, uglabūwīk klāh dī.

21 La nīk yuk, kīs dek mas àyūs-āklila?

22 बा Gāk dākwi lāk Bethsaida; la gāk-yū

da pupāsī bagwanum lāk, hawāknulāk kā pāgaà-klilīì sìk.

23 La dābātl rānund kña pupāsī bagwanum kās le wātilak lotłzau līsas lāknà gūqila; wa gil mīs qātl qiqistauk, glù pāh-ìd tsīs àyasū lāk, la wuklāk, la mas dūqilāh$\bar{i}$ da $\bar{a}$ ?

24 La ị়̂ রikumh-îda kās nīkī, dūqilin kla kñà bībagwānumk he qīx $\overline{1}$ da glăh-glosī, kīsā.

25 La îlīd pāgaā-klilūd tsīs āyasū lāk kayākusas, la dih-īdā masuk, la mīs ek-ìda, la kīyos lā tlāmātl lākēā nāhwā.

26 La yālāk-ìduk kā lālāgīis nenāqā, nīk

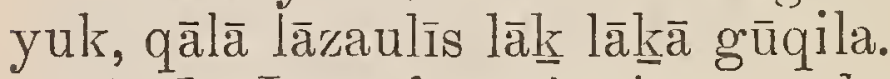

27 Lì Jesus kās-ìd gla wīs discciples, lānākulā lka gūqgagwīs lāk Cresarea Philippi : hīmīs lā wuglā tsi knis disciples yikns la ì kenāqila gla wī, nīk lāh dāknwuk, ungwī la-un lākwā bībagwanumk?

28 Lāh dāk k̂w nītlāk, nīkia, sū ul John knā Baptist; lā glā tā nīkī da wa-ūq Elijah; lī da wa-ūq nīkia, gāy ūtl las lākēa prophets.

29 La ās nīk lāh dāknwuk, wa ungwā tin lāh dāknwūkl? lì Peter nīk yuk, sù mì da Christa. 
30 La mīs tloqālāk kā kìyos dāknwīs nītlā sūs lāk ungwe bagwanuma, yis.

31 La nītlāk yikīks le klī K wanūqas bagwanum tlālāwotlìā̄l glū yākmūdum-kl tsa knwils-knwilyāqī gla wa gī-gikumāyī priest, gla wī da k̦ī-ḳiātīnū tlilā matsawi-kl, glūḳss qilā gilìsī klā kū lā-kl yūdūh pun hwāzīs-kl.

32 Kīs tā knwilāklātlākss lā ì nīks : lî Peter dāh-īduk kās klūlālìk.

33 Aumīs qīkumgāīis lākeiss disciples, la yākkigātluk Peter, nīkia, hāga ulknglāyin,

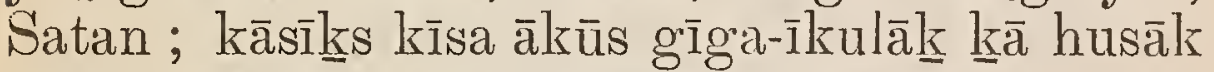
God, he ākūs naukāyi ukzās bagwanum.

34 La klīlāla kni da kīnumì bagwanum gla wīs disciples kā gākīis lāk, la nīk lāh dāknwuk, gil umā hyī ungwe bagwanum nīk kās gākni lāskumī gākeun, wìga hyī wāh-mūta um kzīs

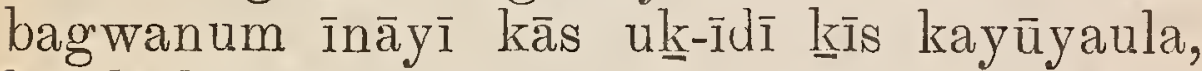
kās lāskumāyì gākenun.

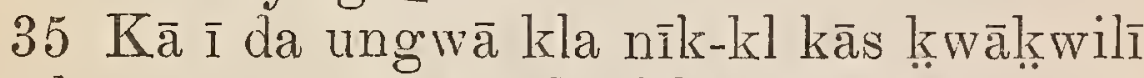
ǩīs bagwānum īnāyì, dāgitl niqila klīk; wa, yik̄i da ungwā kla wăh-mūtã um knīs ba-

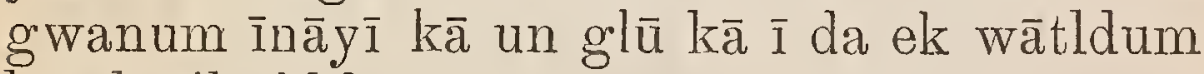
k़wāḳwila klīke.

36 Māsī qenum kla sa bagwanum, kū

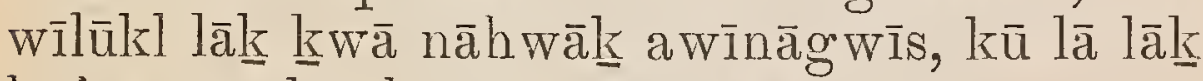
hyisā mas k kīs bagwanum īnāyì.

37 Wa mas lāk kn̄ ka i zawe lāk k kà sa bagwanum kā ìs bagwanum īnāyī. 
38 Yikī da ungwā kla makzā, klin gla wun wātldumi lākn̄ $\underline{\underline{z}}$ da i-autlittāk ya-īksum lìlqilāklayā, hīmīs ūgwākākl mākzūlum-kl tsa Kwanūqā sa bagwanum, kū gāk-kl lāk egalaze sīs Umpa, gla wī da es-ekiā angels.

\section{CHAPTER IX.}

LA nīk lāh dāknwuk, aulin nīkiūkl, yiknwā

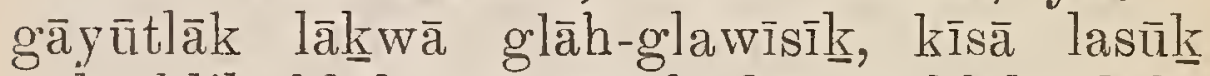
puk-āklīā kluk wānumgīlā, kīs mī klākss dūkwāklilā kluk gōikāsā sa Ike Gīkumī gāk-k̄kl lāk tlāhwāȳ.

2. Wa yikss la ì qātl k̦ukla pun hwās la-āsī Jesus uk-īduk Peter liā les gla wī, hīmīsi James glū John, kās les lākēà iḳiāla nuge

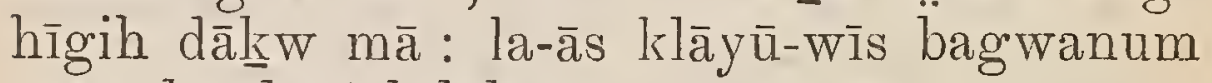
ināyī kā dūqitl dāknws.

3 Lī qītlqeles zilî̄kulā, aulāḳiāl la mulā; kīyos la mulā-kāwāy $\bar{a}$.

4 Wa gākza-ā sī Elijah glū Moses nītl-īd lāh dāknwuk, ya-īḳuntāla glū Jesus.

5 La-āsī Peter yāḳugātl kās nīkīk Jesus,

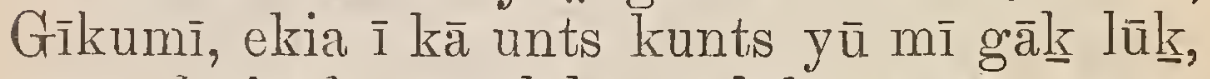
wīga hyinūh gūqīlāk yūduh sumā gūqā, numā kās, hīmīs numā ka-ūk Moses-īk, hīmīs numā ka-ū El Elijah-k. 
6 Kīs la knauklila knīs wătldumī; kā îs lā kitlīh dāknwà.

7 Gākna-ā sì da unwāyī teh-îduk: la-āsa nīkiāle lākeā unwāyì, ga mun tlāhwila Kowa-

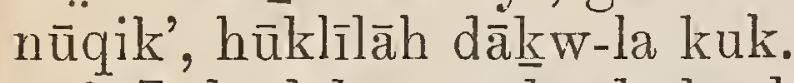

8 Lāh dāknw muls-īd, la kiyos numūq la dūqitl dāknws, hīgāmī Jesus glūh dāknwī.

$9 \mathrm{Wa}$ yikns gāk dāknwa $\bar{i}$ bunūtlil. lākēa

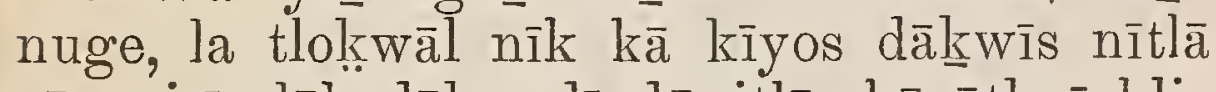
sūs yisīs lāh dāk kū lā klī da K wanūqā sa bag'wanum qilāgilīskl lāknà tlìīi.

10 Lāh dāknw au-um ākīila k

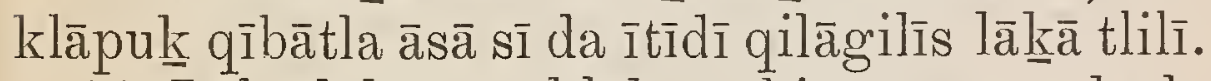

Il Lāh dāknw wuklāk, nīkia, māzī nīkītla sī da scribes yikī kns hī klā gil găâk klī Elijah?

12 La nīk lāh dāknwuk, aula um hī gil gākni Elijah, kās nākīs-tundī k kā nāhwā; wetlā tī da ḳiaduqī qāqīx-al lāk̄i da Kwanūqa sa

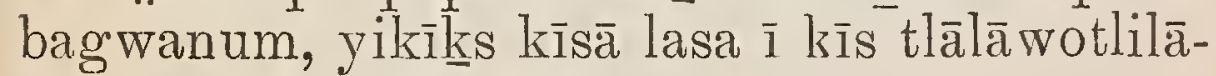
$\mathrm{kl}$, kās wāhmūdumī-kl.

13 Lamīs glin nīkiūklāks gāk mā ì Elijah, lāh dāknw mī sī hī-um qīh-īd kì yi kīis qayūh dāknwī kās qīh-īdaāsuk, la umk k kiātilā-klìā innī mas qīh-ïdaāsū-gwītluk.

14. đT Gilh dāknw mīs gākn-āklil lākna dis-

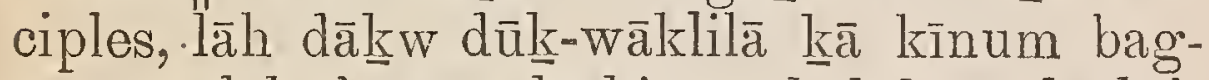
wanum lāk, hīmīsa kì- kxiātīnūk ḳīkayūd glūh dā $\underline{k} w \bar{i}$.

15 Wa hīh-īdā mī sa nāhwā bagowanum 
yiǩs lāh dāknwa ì dūk-wāklilāk, la knünyasas, zilh-wīd lāk kās ì-ākkkiāî̀k.

16 La wuklāh dāk̂kwuk, mās dāknwūs wotl-

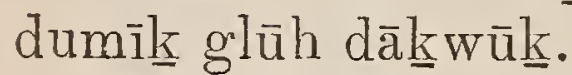

17 Lì da numūqī gāâutl lāknā kīnum bagwanumā nīk yuk, Ade, gāk din wāh sgin ǩwanūqik lūkl, kākns umkno weg uknnūgwād sa yaksamī spirit;

18 Kīilāh-ālīsā nāhwā kuk lāknīs wāhyī laăsa, kǟs eki àhwukstal, kinkia-taulāk tawīk gās gīgīk, lāh zimā-nãqila; lin wāh ukkkiāla

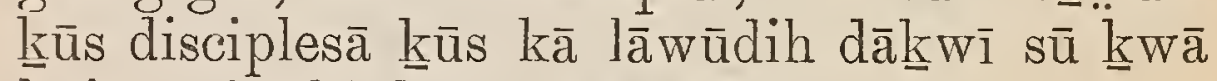
kuk; wiyūkl dāknw tūknwà kuk.

19 La nīk lāh dāknwuk, à yūkl kīyos ùqizālazì līlqilāklī, wīzin wāwāsdum kla kupetlā-kl glūs; wīzin wāwāsdum kla hītlāzaul lūkl, kīlaga tsū gāknun.

20 Wa gāa $\underline{k}$ dākwīs lāk, wa gil mīs dūk $\underline{\text { - }}$ wāklìlāk, hīh-īdā mīsì da spirit yāwīh-ìd lāk, la yāk̂-wātīsa, līhyilīisil āhwukstālā gilīisā.

21 La wuklāk ūmpas, lamā-ūk ketla hī

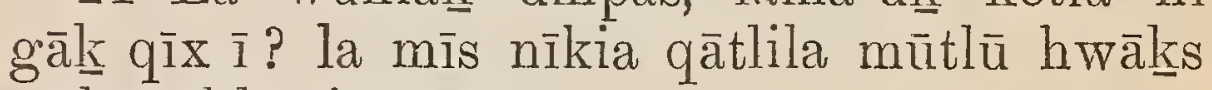
gāla ūtlì k ginānumā.

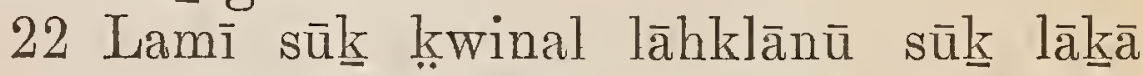
laqītl, glūkss lastānau-āk sūk lāknā wāpī, kās tlātlālūsū-wīq: wa kā glà sū qayūglas nūq lākzuq, wigga wāk wos-īdunūh, kāss wāk găknunūh.

23 La-āsī Jesus nīk yuk, kāsū ūqis lākêu,

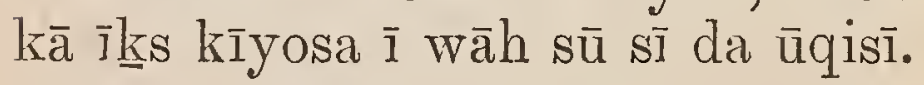


ST. MARK, IX.

24. Hīh-īdā mīsī ūmpā sī da ginānum hāsil nīkia, ūqis mun, wāknātlāla kun wiyūqizālazì.

25 Wa gil mīs̄i Jesus dūk-wāklìlā kāa kīnum bagwānum gāk zilhwil kxāpīkū nāqila,

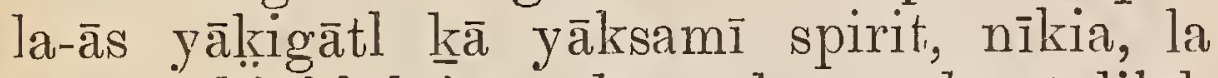
mun nìkiūkl kīlaga lāwe laq, qāiā îtídilāk lālākà lāk lāq.

26 Lī da spirit qākli-g̣ātla yāwīh-īd lāk, gākna-ās lāwe: lī da ginānum hī qīx la

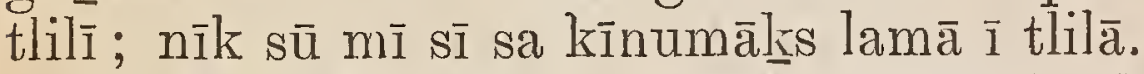

27 Au mīsī Jesus dābātl-zānunduk, kās nīkūstau-līsīk; la mīs g’ākzwilisa.

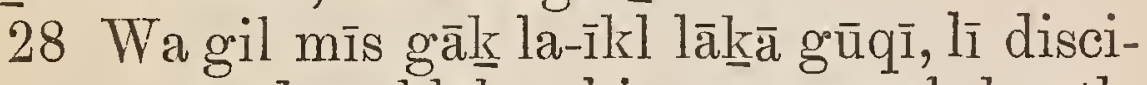
plesas awāsīd wuklāk nīkia, māzaunūh kīsītla lāwe masuk.

29 La nīk lāh dāknwulk, yik qīxdumas kīyos

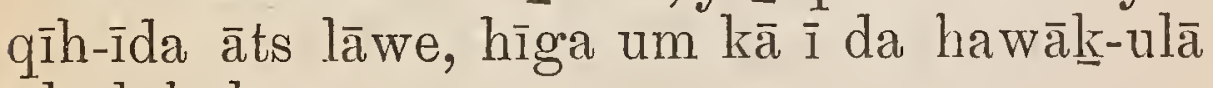
glū kরīkulā.

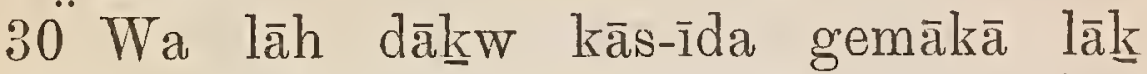
Galilee; kīs tā nīk kà kauklilīs ungwe bag’wānumk.

31 Yikss la ì nītlā kīis disciples, nīk lāh dāknuk, yi kīi da Kowanūqas bagwānum la um zawe lāk àyasaus bagwānum, lāh dālnw klī kīlāh-ìd kluk kā tlilīs; wa gil umkl wīs lākl. tlil-kl, lā klī qilāh-ìd-kl ìtīd-kl, kū lākl yūdūh pun hwāzìs klī.

32 Kīs dēknw tā āyūsilāk wātldumas, lāh dāknw um ka à wīs halāla wuklāk.

33 Wa gāk dākn lāk Capernaum : wa gil 


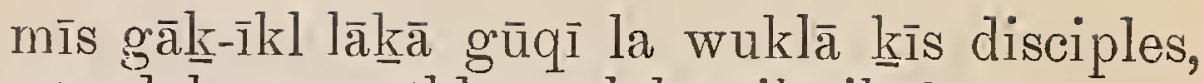
mās dāknwīs wotldumā lāk kā tihyilā?

34 Auh dāknw mīs knwīklātla: kāh dāknwīs

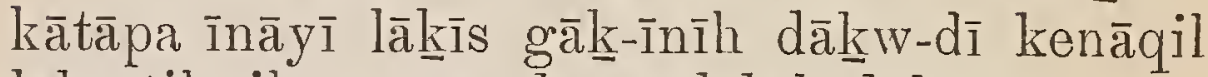

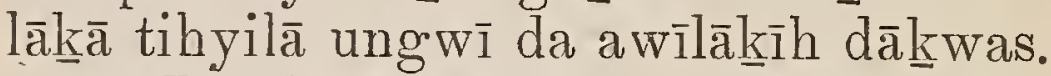

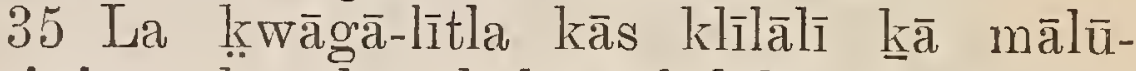
g*wigiyū ; la nīk yuk, kū nīk lākn̄ ungwe bagwanum kās gālākumāȳi, mākstūkglī klī sa nāhwā, glū hīlūbātl-zān̄i klisa nāhwā.

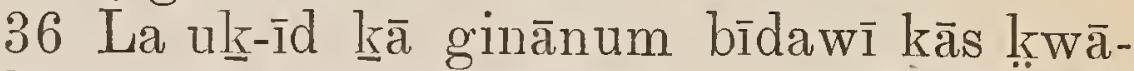
kulìtlīs lāk nuḳ̂kuki-lìtl dākñas, la kutl-ìduk, kās nīki lāh dāknwuk.

37 Yik ungwā kla dād̄̄̄ā klāk gā kla qīx-kl ginginānum-in̄̄ k̂w klik lākun glīkurnī, hī-um dādāla gāknun; wa yik̄i da ungwe

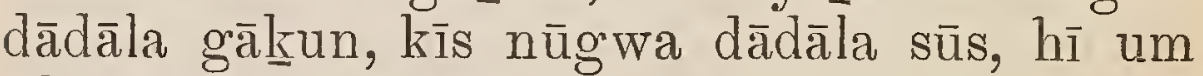
glī yālākum nūqa un.

38 Lī John nīk yuk, Gīkumì, dūqilā nūhwā

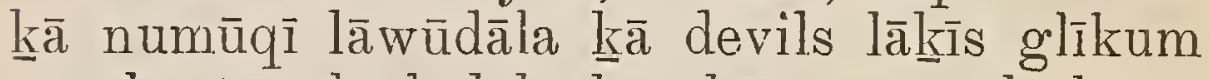
ùs, là tānūh bulāk kā kīzīnāyas lāskumī gāknunts.

39 Aumīsī Jesus nīkia, qālā bulāk; kā ìks

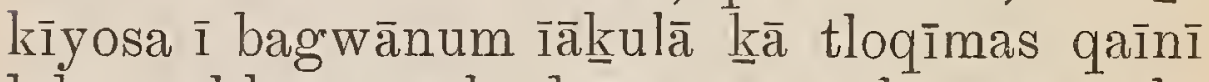

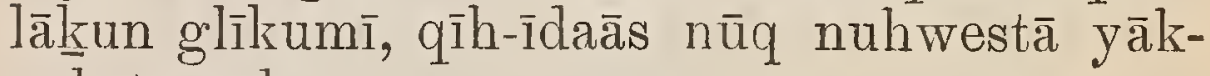
pāksstā gākzun.

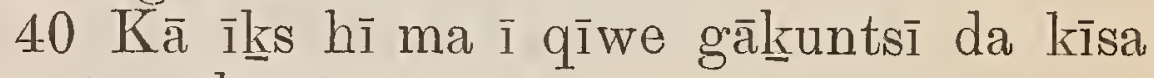
hāyūta gāknunts.

41 Yikn̄ da ungwā kla zaw klū-klas numīkn-

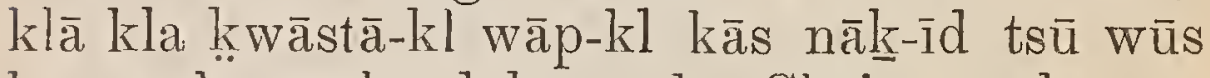

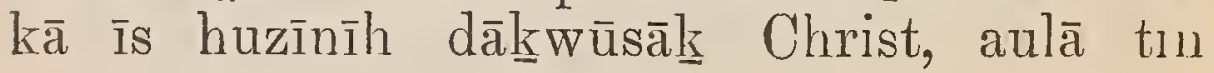


nīkiūklā kīkns lau-kl mī klā kīis qenum kla lāk.

42 Wa yik ungwā kla qih-īda mas kluk numūqa lāk gada ginginanumk ūqis gākun,

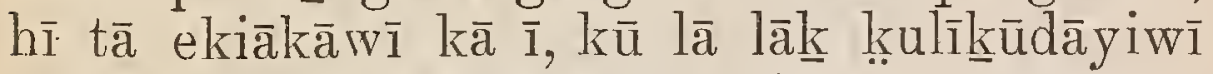
wālasa tīsum lāk k kūḳụnes, kās le zuksstānū lāknà klāsāq.

43 Glū kāsū qih-īdā matsū lāk sīs āyasū wūs, tūsū dāk: he àkūs egāsī lāzau lāk qilà

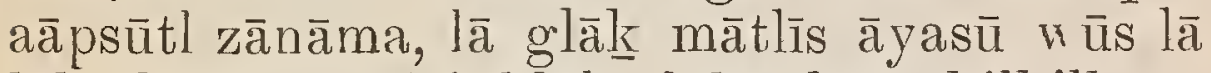

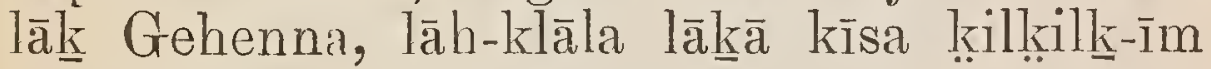
hyìhyīkula.

44 Glū kāsū qih-īdā matsū lāk sīs gūgrwayū wūs, tūsū dāk; he ākūs egāsī aūzagīla lazau lāk qilā, lā glāk uknnūgwādes mātlī gūugwayau lā zukkklānū lāk Gehenna.

45 Glū kū qih-īdà mas lākīis kayākus ùs lūkl, qilpūdāk: he ākūs egāsì lazau lāk gīkāsa sĩ da Ike Gīkumī numskum staula ma, lā glāk uknnūgwādes mātl-tsumì kayākusā, lā zuǩk-klānū lāk Gehenna:

46 Yiknā kīs kla tlìā īnūkwās klis ābānīh dāknwas, glū kīsa ḳilk-īnūǩs hyīhyīkula.

$47 \mathrm{~K} \bar{a} \overline{1}$ da nāhwā bagwanurnks dums-hyaāqi klis hyīhyīkula, gla wa nāhwa yāqum dums-hya-âa klis dums-hye.

48 Ek ìda dums-hyī: wa kā glū kīyohwīdilākni dumpā ìnāyas, wīzisā tà klas kā dumpih ìdāyūs? dums-hyi-āq lā, glū kās numh dākwila ūs. 


\section{CHAPTER X.}

LĀ geh-īd lāk kās gā qīsütas Jordan: gāk ka-ās ìtīdì da kīnum ba-

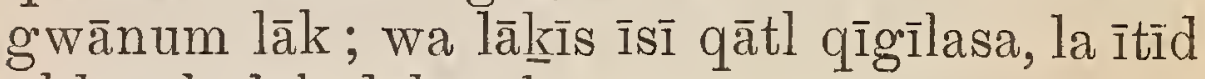
glīks-āla lāh dāk̂twuk.

2 Gāk ka-ā sa Pharisees lāk, grwānāk wuklāk, ek ma ì kā qīsdāmasì sĩ da numūqì bagwanum kīs kunumā?

3 La nānāknmī kās nīki lāh dāknwuk, mās wīs gla wātldum ūtlas Moses lāh dāknwūkl?

4 Lāh dākew nīkia, nīk wūtlī Moses kā

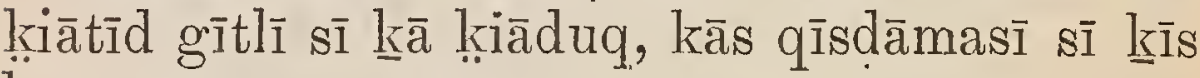
kunumi.

5 Aumīsì Jesus nīk lāh dāknwuk, kegì kā

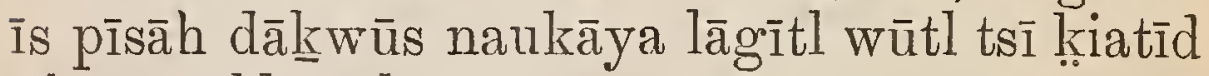
yisa wātldum kās:

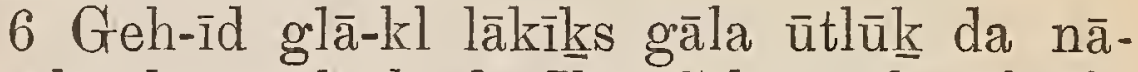

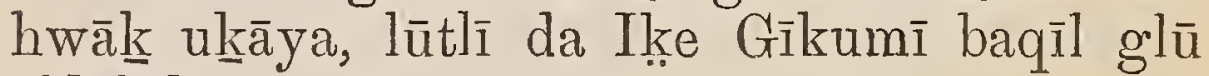
zidākīla.

7 Hīmĩs lāgītl klisa bagwānum bo sīs ūmpī gla wīs abumpī, kās le lāknīs kunumī.

8 Là klīks mālūqa ì numūq um-kl lā-kl, kās kīsì-kl lā-kl îtīd-kl mālūq-kl, au-um glātl lā-kl numūq um-kl.

9 Lāgītl klisa le āknūtsū sa Ike Gīkumī, kīs klila gwītl-zun tsūs numūqa bagwanum.

10 Gil mīs la-îki lì da disciples wuklā knaàk lāk gada wātldumk. 
11 Wa la nìk lāh dāknwuk, yikīi da qīsdā mas kla kīis kunumī, kās kugādih-īdī sa ūgwila mì, hì um yāksamī qīh-īda-asas.

12 Glū kū hīlā kī da zid̄āk qīsdā mas kīis t]āwunumī, kās tlāwādih-īdì sa ūgwila mī, lamīs yaksamì qīh-ìda-asas.

13 qा Gāk dāknwi sa gīnginānum unīkwi

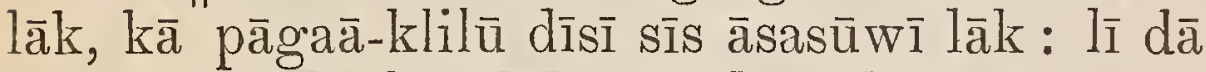

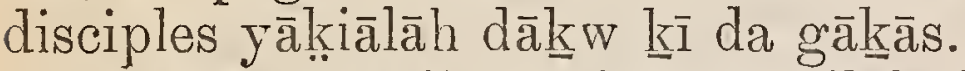

14 Gil mī sī Jesus dūkz-wāklilāk, la kīs ekàkik, la nīk lāh dāknwuk, gāk lehia gingin-

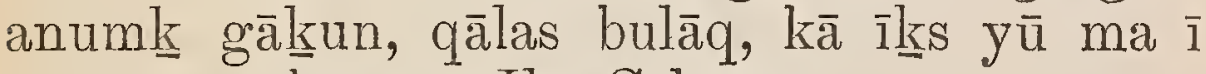
qīx zāts gīkāsa sa Ike Gìkumī.

15 Aulin nīkī̄kl, yik ungwā kla kīs dāđāla kluk gīikāsa sa Ike Ğìkumì hī qīxī ginanum bìdāwī, kīsā las tī la-īkl lāk.

16 La k़utl-ìd kā ginginanum kās, ekīlīk, klukw à sīs àyasū lāh dāknwuk.

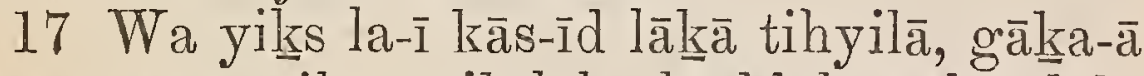
sa nurnūqū zilūnāqil lāk, la klāk-wālìs lāk, kās wuklīk, Ek Gīkumī, māsin qīgīlas kla kun lo-klīk hīmunīs qilà?

18 Lī Jesus nīk yuk, māzīs glīk-ìd gîtlas ekī gāknun? kīyosa às ekia hīga-ma $\bar{a}$ sa Ike Gīkumì.

19 Kauklila ma-ā kūsā ks̄a wātlduma sa Ike

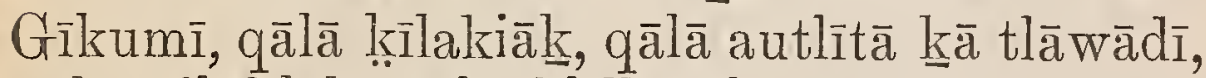
qālā gilūklāk, qāà klīlḳwāla sīs bahwit tūs, qālā nānūtl-tsīlāk, māyāhyilāla kīs ūmpūs gla wīs abumpūs.'

KWAGUIL. 
20 La nīk yuk, Gīkumī yūwī-stā mun

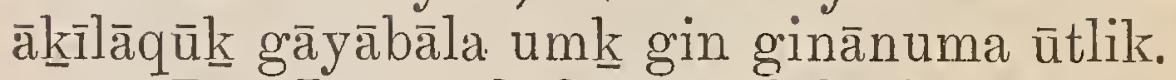

21 Lì Jesus dūdūkns-unduk, la tlāhwila nūqs, la nīk yuk, numīs wayūglānuma ūs: hāga lāknù kn̄is māmîkiasa ùs, kās yāqā ūsā

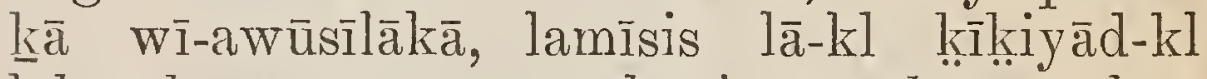

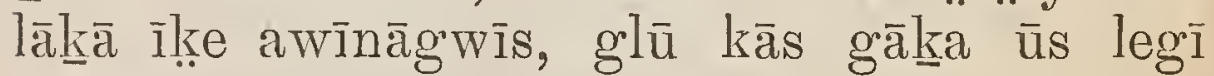
gākun.

22 Aumīs yekilk-idis wātldumas, la zihyilīs naukāyākss la ì kāss-ìdā; kā īs klūma ìnāyi kịịịiyādā.

23 Lì Jesus mulmulsīlelāh-īda, la nīk knīs disciples, aula wïstā tlāhwātla kā $\bar{i}$ da uknnugowāde sa k़inumì dāla kās la-īkl lāk gīkāsa sa Ike Gikumi !

$24 \mathrm{Li}$ da disciples knunyāsas wātldumas: aumīsì. Jesus îtīd nīk yuk, sāsum, aula ās tlāhwātla kāh dākñì da hīlīkule sīs kịikiyāda īnāyī kās lāīkl lāk̂ gīkāsa sa Ike Gìkumī !

25 Hūtlumātla kāwāya i kā $\overline{1}$ da gūdan kās le lāhsau lāk qoḱglāya sī da k̦unāyū, lā glā

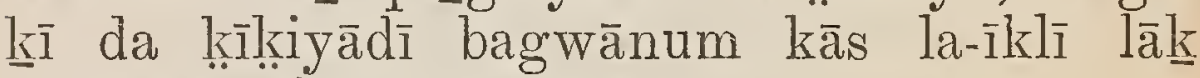
gīkāsa sa Ike Gīkumī.

26 Wa lā wìs gla aula-ḳiālāh dāknw la kunyāsa, nīk yuk, wa ungwā zau tā klī da hītlilā klā?

27 Lì Jesus dū $\underline{k} w \bar{i} d$ lāh dāknwuk nīkia, tlāhwātla umhs g]ā tā kā bagwanum, kīs glā

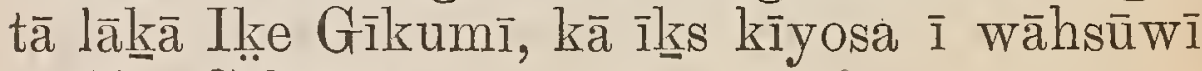
da Ikne Gīkumī. 
28 La àsī Peter nīk yuk, dok, gānūh la

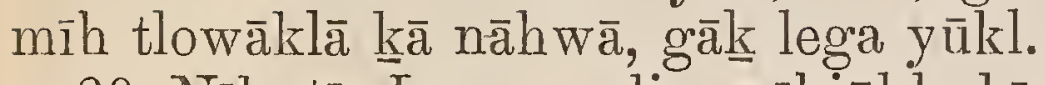

29 Nìk tī Jesus, aulin nīkiūkl, kīyosa ì bagwanum kñ le bo sīs gūq, gla wīs nātl-

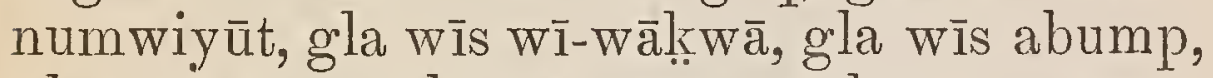
gla wìs ūmp, gla wīs sāsum, gla wīs awīnā-

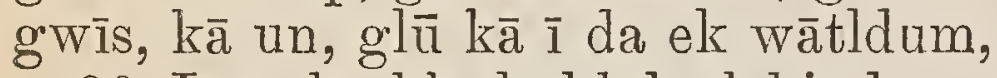

30 Lā glā klī lo-kluk lāksinda punā kla läkūk da bunīk awīnāgwīs, gūqu, glū nātl-

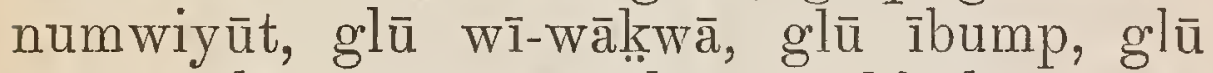
sāsum, glū awīnāgwīs, glū māmīklātla sa-wa; hīmīs lākī da îtàlìs kla ì hīmunīs qilā.

31 Lā glā tī kīnumī da gā̄ā-gīwāya, lā-kl

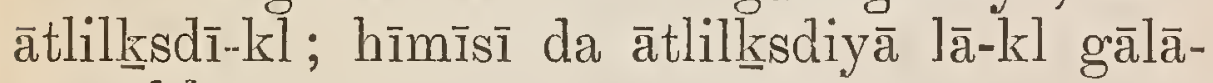
gīwī-kl.

32 था Wa lāh dāk̂ mīs ke-nāqil qayūtlil lāk Jerusalem, gāla-gīwāliss tī Jesus yih

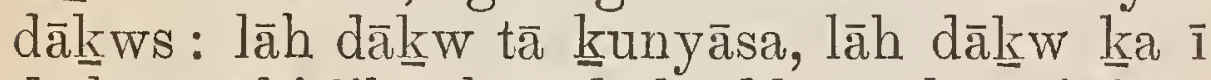

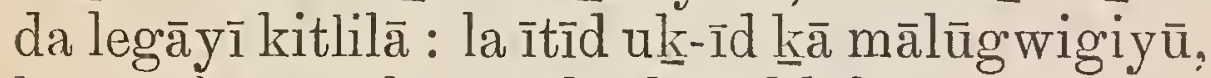
kās nīt]ī sa nāhwā qīh-īdā̄s kluk.

33 Nīkia, dok, lamunts lā-kl lāk Jerusalem, lamīs lā klī da $\underline{K}$ wanūqa sa bag'wanum zawe-

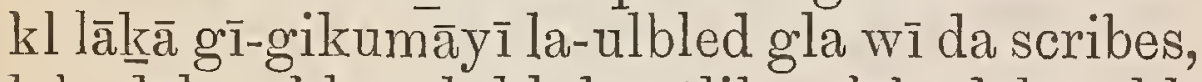

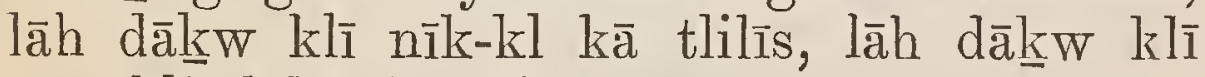
zaw klis lākā Gentiles;

34 Lāh dāknw klī a-umt]ātlā klis, qī-qisumā kluk, glū hwisā kluk, lāh dāknw klī tlīā mas kluk; wa kū lā-kl yūduh punhwā zīs-kl lāklī qilā-gilīs-kl.

$3 \overline{5}$ Gāk k̇a-ā sī James glū John yik sāsumas 
Zebedee nuhwāh-īd lāk kās nīkīk, Gīkumī, nīkinūh kās hī ùs qelā kā unūhwunūh ukkkiāla sū kla lūkl.

36 La nīk lāh dēk $\underline{k} w u k$, māsīs qayūh dāknwa ùs kun qīgìlas kās?

37 Lāh dāknw nīk yuk, hīd kās zaw ùs

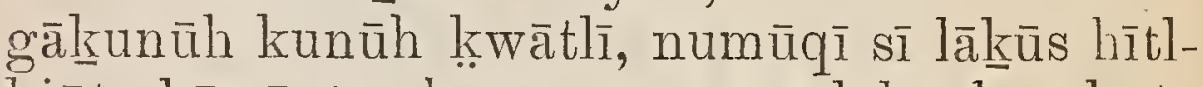

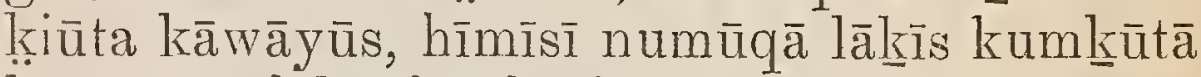
kāwāyūs, lākīis hyāhyīlanūsa ūs qīxdum-kl.

38 Aumīsī Jesus nīk lāh dāknwuk, kīs dāk̂wa àkūs kauklila kīis uḳkiāla sū wūs:

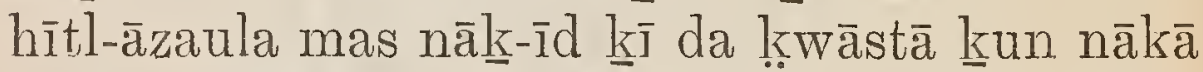
sa wa, glū baptize ìd tsū sa baptize ìdāyū gākun?

39 Lāh dāknw nīk yuk, hītl-āzaula munūh : lì Jesus nīk yuk, yiki da da k̦āste un nākā sa wa lāh dāknw ums nāke-ìd kluk, glū wì da baptize zīnĩ baptize-īdāyu gāânun lamī baptize ìdāyū-kl. lūkl :

40 Wa yiglāk knwātla lāk gin hītl-kīutà kāwīk glū grwin kumknūtā-kāwīk kīs glā nūs kun zawya, hus dāknw um glī kī da le qātlātlagīili gītluk.

41 Wa gil mīsì da nukoq la wuklilā knik, lāh dāk ww wānīkās James glū John.

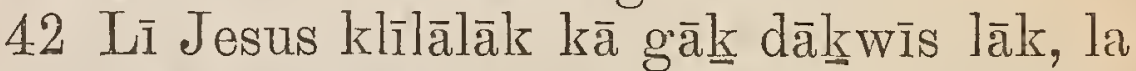
nīk yuk, kauklilāh dāknw um sīḳs gīgaḳāla

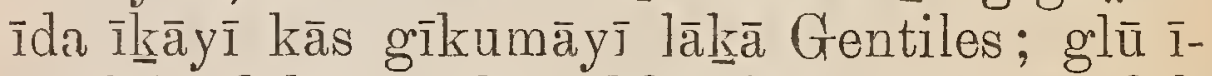
awì̄āh dāknwà sīkns klīlumkāh dākswa ì lāh dāknwuk. 


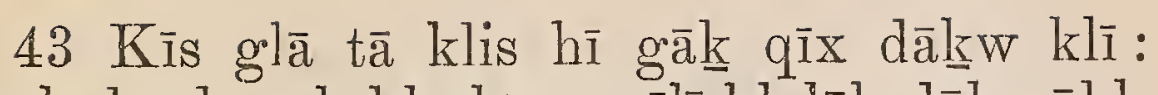
yiglā k̄i da nīk kla kās awīlì-kl lāh dāknw hīlūbātl-zan̄i klī yūs.

44 Wa yikî da ungwā kla nīk-kl kās gā̄ā-

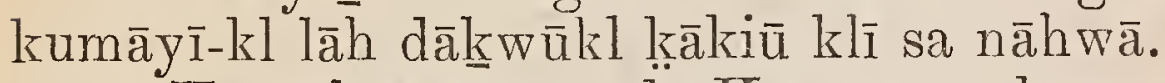

45 Kā aula ìnāy ā sī da K wanūqas bagwa-

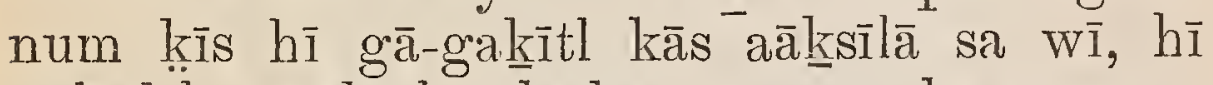

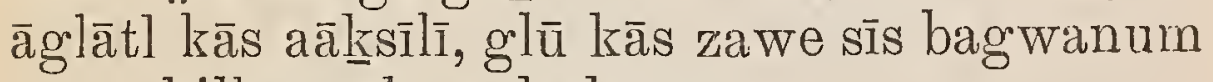
ināȳ kilhwās kà ì da kīnumī.

46 oा Gāk dākw lāk Jericho: wa yikss lā $\overline{1}$ lotlzaulīs lāk Jericho gla wìs disciples hïmī sa kīnum bağwānum, yị kwanūqas Timæus,

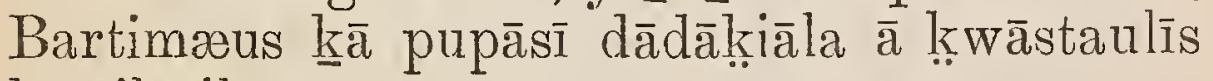
k̄à tihyilā.

47 Gìl mīs ḳautl-āklilā kīkns he-ī Jesusas Nazareth, la-ās lāḳwigātl nīkia, Jesus, yūkl Kivanūqs David, wāk ki-ida gāânun.

48 La yāḳiāla sū sa kīnumī, kās ḳwīklātlī: aumiss hutīd hāsil lāḳwāla, Yūkl K_wanūqs David, wāk $\underline{\underline{k}-\overline{1} d a}$ gā $\underline{\underline{k}}$ un.

49 Lì Jesus wulga-uls, la nīkia, klīlālāh dāknw lāq: lāh dāknw klīlgātl kā pupāsì bagwanum, nìk yuk, ekīkulāla, glāknwidaga, la ums klīlāla sūs.

50 La uḳūd kīis nuhwunāyī, kās duhwilsī, kās gākēi lāk Jesus.

51 Lì Jesus nīk yuk, māsīs qayau ūs kun qīh-īdaās kās? lì da pupāsī bagrwānum nìk

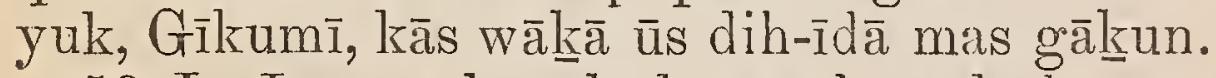

52 Lì Jesus nīk yuk, hāga ek umk, la ums 
hītl-tsīstā matsū sīs ūqizīnāyūs: wa lamīs hīh-īda um duqilāh-īda, kās lăskumā yīk lāk tihyilā.

\section{CHAPTER XI.}

WA gilh dāknw mīs gāâk nuhwāh-īd lāk Jerusalem, gā $\underline{k}$ lāk Bethphage glū Bethany, lāk $\underline{\bar{x}}$ da nuge glīkādis Olives, la yālāk-ìd tsī da mālūqi lākīs disciples,

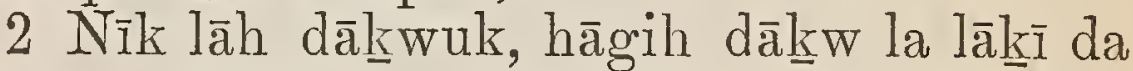
gūqila nuk-kxiūì sus, gil um-kl wīsus lāzaulīs-kl lāk, lăh dāknw klis hīh-īda um-kl dūk-

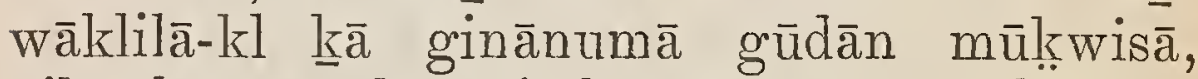
yikā kìs ma k़wegind tsūs numūqa bagwānuma, qītlulsālāk, kās gākna-ūsas.

3 Gil um lāk wìsis nīk sū lāk, māsīs hīgītla qīgīlī, ]āh dāknw klis nīk-kl, uk-īkssda sū gwā sa Gīkumāya; hīh-īda um-kl wīsī nīk-kl kā gāknīs.

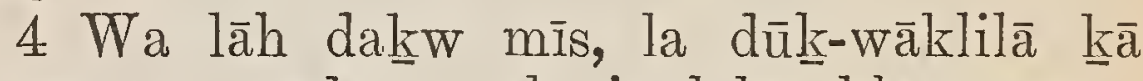
ginānumī gūdān māḳwis lāknā klāsanauyī; lāh dākn qu qìtlulsāk.

5 La àsa gāyūtlī lāknà glāhglosī lāk, nīk lāh dāk

6 Lāh dākñw nīks qayūh des Jesus kā wātldum-ūgwittl dākws: wa lāh dāk mis mis hītl-keāla umk lā.

7 Gāk dā $\underline{k} w \bar{i}$ sa ginānumī gūidān lāk Jesus, 
lāh dāknw klubīgin-dāla sīs qītlqela lāk, lī Jesus knwegindulk.

8 La um kâa-à wīsī da kīnumī klupulsilā sīs qītlqela lāknā tihyilā; lì da wa-ūqā sī da māmemī, yik tūzānumh dāknwas lāk ka awīnāgwìs.

9 Wa yih dāknw knì da gāla-gīwāyì, hīmīsì da ulkeglīh dāknwī hāsilas, Hosanna, ek wīs tī da gầk̄i lāk glīkuma sa Ilke Gīkumī:

10 Ek wīs tī da gīināsa gāk-kl, yik gīikāsa sints ūmp wūtla ì David: Hosanna lāknī da ìkiā-kāwì.

11 Lì Jesus lāzaulīs lāk Jerusalem, lā laìkl lākāa temple: wa gil mìs qâtl dūqā kīi da nāhwā, la um zāqā, lā lawils kās le lāk Bethany gla wī da mālūg wigiyū.

12 Wa kīi da lā tlinsā, yịks gāk dāknwa ì lotlzaulīs lāk Bethany, la pūskuh-īda :

13 La dūqilà knā fig mis lākēa qīsāla māmemk-klaula, gāk lāk kās dūqīk nūnawìmas lāknā lāk: wa gil 'mīs gāâk-āklil lāk, au mīs hīga mī da māmemì khā sūs lāk, kā kī̄īnī mas klūp dum sa figs.

14 La yāknugātl kās nīkīk, kīyos laga bagwanum humâ-īnūk kluk nūnawīmasa lūkl gāyābālā-kl lāq, lamīsì disciplesas wuklilā umk.

15 Wa gāk dāknw lākn Jerusalem : lā la-îkl lāknā temple, la zukum wilsilāh īda knā lākeulāh dāknwì gla wa kilhwā lāk awìklile sī da temple, klīhyim gālītlilāk kīkilhw dumītl dākw de 
sa klāyau sa dālā, glū kñwātla ās dāknw de sa lākule knā pīpāklūmas;

16 La kīs knād hītlḳālāk numūqa bagwānum

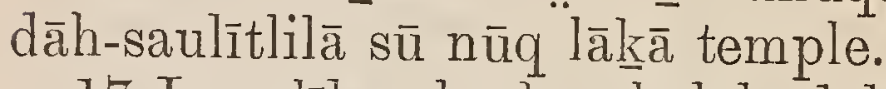

17 La glīkss-uh-ìd, nīk lāh dāk̂kwu, kīsa i k̦iaduqa à, Kun gūqui glīkād klis hawāknulazì

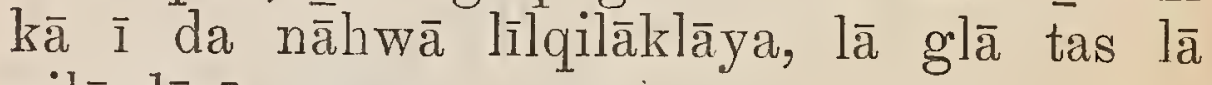
gilūglāzì masuq.

18 Wuklilā mīsī da gīgakumāyì la-ulbled gla wī da kī-ḳiātīnūk yikns la i nīkia, la āle

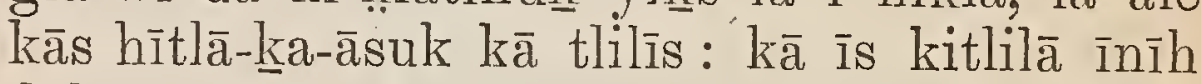
dāknwas, ks̄a $\overline{1}$ da kinum bagwānumkss nāhwā ma $\bar{i}$ kunyasas wātldumas.

19 Hìmunātla mīs lā kzūk zāzaqāk lotlzaulīs lāksā gūqila.

20 Wa yikss lāh dāknwa ì hiyākulā knā kaāla, lāh dāknw dūqilā kni da fig mis au-um lā hwilsìda geh-ìda um lāk $\underline{a}$ k klūpukī.

21 Lì Peter hamulḳwilā nīk yuk, Gīkumī, doknwā fig misā kūs yāḳigātl tsū wūtl au mūk lā hwiltsisistā.

22 Lī Jesus yāḳnugātl nīk lāh dāknwuk, ūqislā kzā Ike Gìkumī.

23 Kāk gin auli gin nīkiūkl, yiknā ung'wā kla nīk kluk gada nugek, wīga kliquilīsuk kās

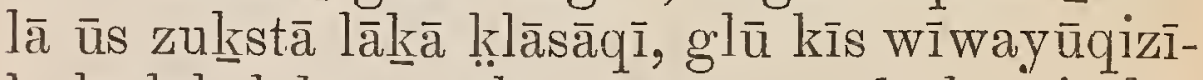
kulā lāk lāknis naukāyì, au um glātl ùqis kīis wātldurnāks hīmī klì qelā klī; lā klī lo kluk.

24 Hīmī sin lāgìtl nìkiūkl knā nāhwā yūs hawāknzulā gītl glū uk-kịiāla sū wa, ùqisukss la 
mā ākūs lo kluk, lāh dāknw mī sis aulā-kl lo kluk.

25 Wa gilh dakw mī sis glāknwātla hawāǩnulā, klalîwīlā kāsū qīh-īdaās tsū nūgwaàgiūtl lākss numūqa bag'wānum; kā ūgwākī sîs Umpa ūs yilki da he lì da ìke klalīwī kīis hūsūs yāksum qīgīlasa.

26 Wa kā glā sū kīs lāk dịgiklilū-dilākn,

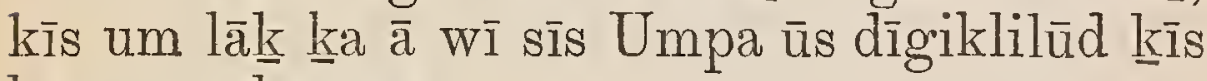
hūs ūs yekīnāyā.

27 बा Gāk dakw îtīd lāk Jerusalem: wa

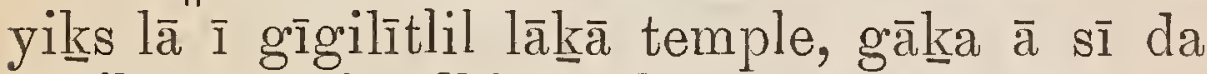

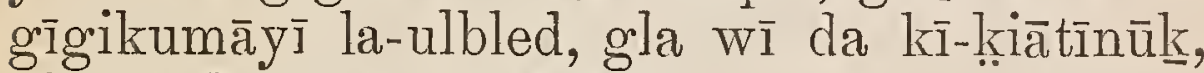
gla wī da k़wils-knwilyāqī,

28 Lāh dāknw nīk yuk, wīzisa zau sī knūs

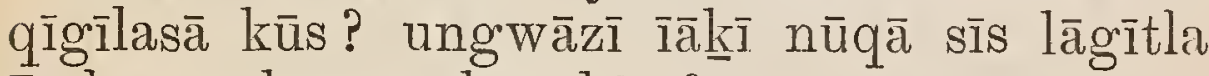
ūs hì qīgīlūs qīgīlasā kūs?

29 Lì Jesus nīk yuk, wuklā klī sin klūkl lāknā numh-īdatla, la mī sis nītlā-kl gākeun, wa lā-kl wìs glin nīk klūklas uke nūqā sin lāgītla hì qīgìlin qīgìlasīk.

30 Yik baptize zīnā yūtlas John, wīzis wūtlī, gāyūtl mūtlā i lāksā ìlke, glū bagwanum zis mūtl? nìtlā-laga gākzun.

31 Lāh dāknw kị̄kayūd ḳwilīxma, nīkia, gil

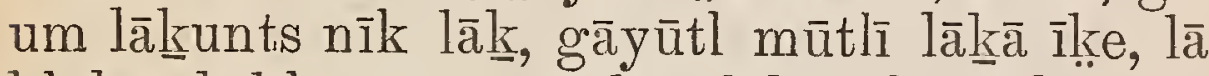
klūk nīk-kl, māzau tīs kīs dāknwitl wūtla ūqis $\mathrm{k} \overline{1}$ ?

32 Gil mī lāk ga glints nīk lākn, gāyūtl um lāk bagwanum, kitlìlāh dāk $\underline{\underline{k}}$ tī sa nāhwā 
bagwanum; kā ī k̇s nāhwā ma ī nīk kīkes aulakịăla ūtla prophetī John.

33 Lāh dāknw yāḳugātl kās nīkīk Jesus, kīsunūh knauklìā: lī Jesus nīk lāh dāk̂kwuk, kīs um kna un $\bar{u} g w a \bar{k} \bar{a}$ nìtlū klas uke nūqa à sin hīgìtlī qīgī̄ā gin qīgīlasik.

\section{CHAPTER XII.}

LA yā ḳugàtl kās nīkī sa nīk-dumā lāh dākn-

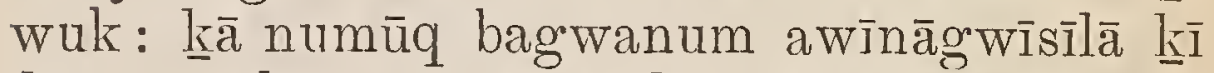
da numzakīs awīnāgōis kās zāmās k kā grapemis, la kātlbatsīs-tunduk, la lāpīd kā wine-

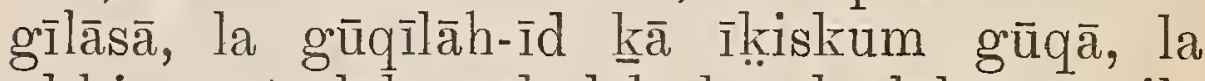

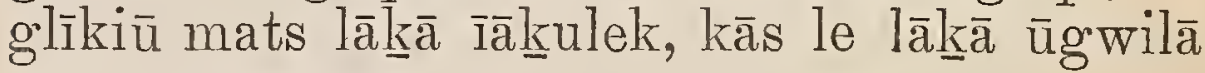
um awīnāgwis̄ā.

2 Wa yikns lā i klūp dum sa grapes lā

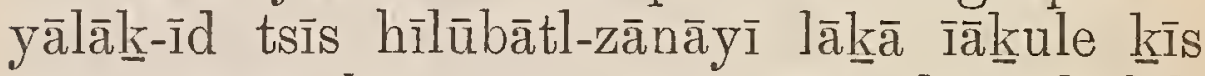
awīnāgwìs, kās zaw sū wì sì da īâkulek

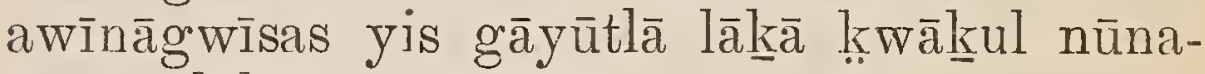
wìmas lāknā awīnāgrwìs.

3 Lāh dāknw uḳ-ìduk, kās ḳ̣īāk-īdìk, kās keh-ìdık lūp-naqila.

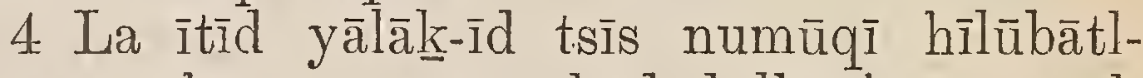
zānāya, hīmīs au-um knād lulkutta mātsūh dāknws lāk hyūmsas, mumh-zigīlākīs qīh-īdaās dāk $w a \bar{k}$.

5 Là ka à îtìd yālāk-ìd tsa numūqī; auh dākñw um ̌a à wîs kīlāk-īduk, tlilā masuk; 


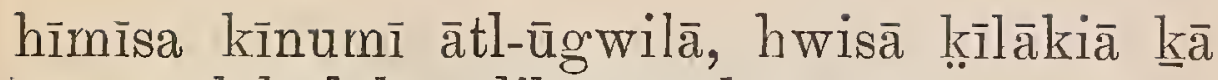

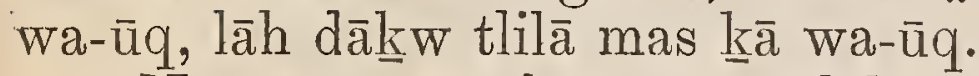

6 Numūq mīsì kīs mī yālāk-īdāyūs, kīs

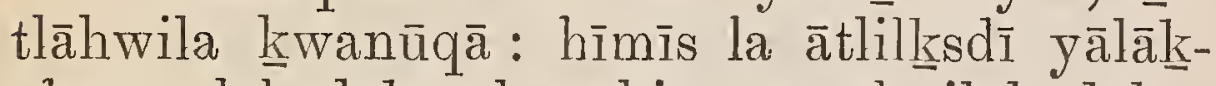
ìdāyūs lāh dāknwuk, nīkia, māyāhyilāh dā $\underline{k} w$ klī kun knwanūqì.

7 Aumīsī da īâkulìisisā knā awīnāgwīs nīk dāknwā, ga um hī-lā kluq; kīlaga, kunts ḳīlākìdīkuk kā tlile sik, lā klints nūs klukkūk da awīnāgwīsīk.

8 Lāh dāknw dāh-īduk kās kṇilāk-īdīk tlìā masuk, lāh dāknw zukwwutlzaulīsāk lākēa awīnāgờīsī.

9 Wa māsī qīh-īdaās kla sī da gīkumāya

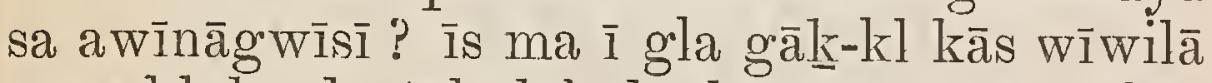

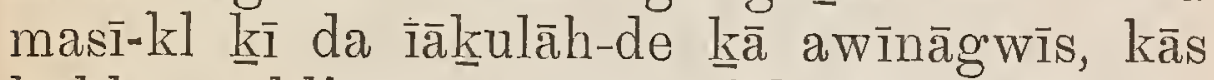
le-kl zaw kilisa awīnāgwìs lāk̂ ătl-ūgwila um klā.

10 Kīs dāknwas kরiākxiāduq-sīla innūk gāda ḷiāduq ga; knā tīsum yik yākmūdumā sa

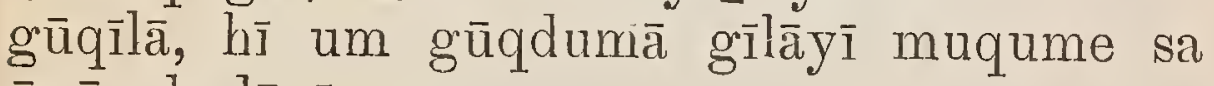
ūnūzukssdāyī :

11 Ga um ìâkī sa Ike Gīkumī, ga mī sints kzunyāzum düqitlik?

12 Lāh dāknww wāh nīk kās wegī ukz-iduk, au mīs kitlilā sī da kīnum bagwanumā; kà îs dūqilāh dāknw ma ākss hīh dāknw ma ì nīnākītlì yisīs la wătldum lāh dākwuk; lāh dākn au um bos, la kās-īda.

13 T Lāh dākn yāà̄ 
lāknā Pharisees gla wī da gāyūtlī lāknā Herodians, kā hāyātla kna ì sīk lākn̄is nāhwā wātldumā.

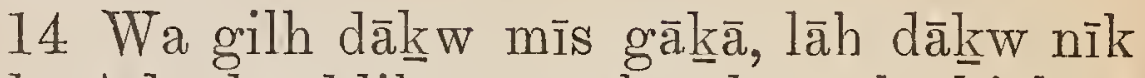
yuk, Ade, k़auklilā munūhwā kns aula k़iāla ā

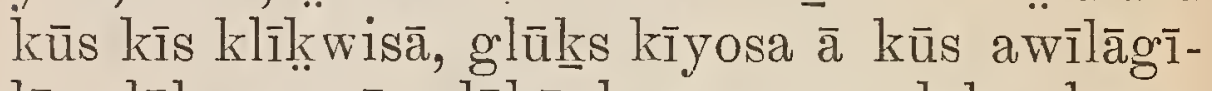
lāq lāk numūq lākē bagwanum lāk : kàa is kīzīnāyūs au-um, māyāhȳātla sū nūq lāk

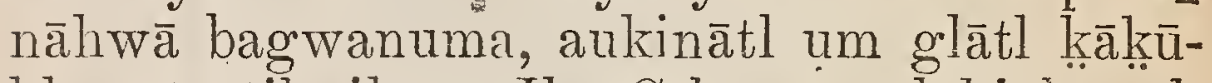
klāmats tihyile sa Ike Gīkumì aulaḳiāla: ek ma ì kunūh hutlākī sunūh hutlākumāk Cæsar, glū hì um egāsī kīs hutlākās lāk? wīnī da ekia lāk, zaw mas lāk, glū kīs zaws lāk?

15 Kauklitā mìs glīk klīiìh dāknwas, nīk lāh dāknwuk, mā zīs gwānāh dāknwītla gākzun, kīlats dāle gākun, kun dūk-wīd tsa wā.

16 Gāk dāknwīs: la nīk lāh dāknwuk, ungwāsīk kūqumī gada kịàt-tsumì gākuk? lāh dāknw nīk yuk, hus mūḳwāk Cæasar.

17 Lī Jesus nīk lāh dāknwuk, zaw umāts lāk Cæsar yikī da husāk Cæsar, glū kās zaw ūsā kzì da Ike Gīkumì yisī da husā knā Ike Gìikumī : lāh dāknw knunyāsas.

18 đI Gāk dāk nīkiākzs kīyosa ì qilāh-ìda; lāh dāknw wuklāk, nīkia,

19 Ade, kịầi dūtlī Moses wūtla kā unūh, gil umā hyī tlilī nūle sa numūq baginānum la kīyos knwanūq lākīis kunumh dī, kà les 
kunumh ìd sīs zāyāh dī kās sāsum nūq wìdī lāk, kā is nū]āh dì.

20 Uglabūq wūtl tī da numī mūtla; wa yikni da nūlas tukumaȳi kugādih ìda, la tlil kīyos sāsuma:

21 Lī da zāyà kugāàih-īdis, la tlilā, kīyos

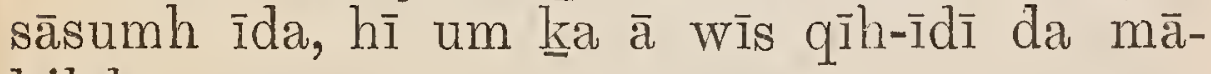
kilek.

22 Nāhwā mī sīkss uglabūqa ì kīyos knwungwădih ìdunūq lāk, la à kna ās tlilì da zidāk.

23 Wa ungwā kli lāh dāknw kīks uglabūqa ì kugād klis lākzi da qilum-gilīs dum klā? kā nāhwā īnì mūtlā sīkss uglabūqā yūtla kugādih ìdūtl tsa numūq um zid̄ākā.

24. Lì Jesus nīk lāh dāk̂̉wuk, kīsa sìtl hīum klīqās dāknwwīsì kā, kīzīnīh dākwūs kau-

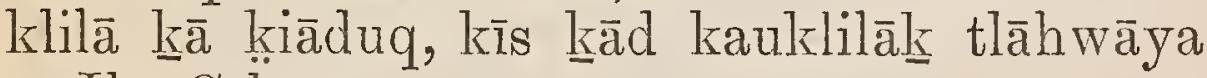
sa Tlke Gīkumī.

25 Kā kīzīnī kla sī lā-kl kī-kugād-kel kū lā-kl qilumgilīis klī da qilumgilīs kla lāksā tlilī; lkīs-kl knād lā-kl hāyāsi-kiaulā-kl au-um

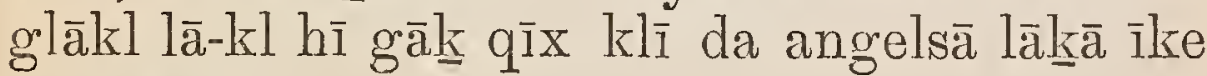
awīnāgwīs.

26 Wa yiglā kni da lāa tlilā, yikss lāh dāknwa

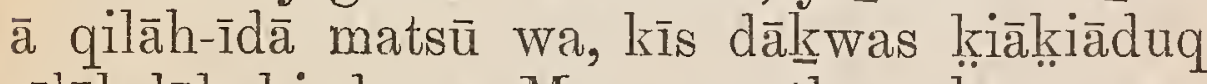
sîlāk lāk kiaduqas Moses wütla $\bar{a}$, k̦āa qāqixāla lāknī da kzusbīh, qīh-īdaās wūtla sa Ike Gīkumīkss la ūila yāḳugātl wutl kī, nīkia, Nūgwa-um Gīs Abraham, glū Gīs Isaac, glū Gīs Jacob wutla. 
27 Kīsa às Gī sì da lā tlilā, he āglas Gī nūq sīyī da qil̄a: wālasītl dāknwūs klīqa.

28 Numūqu tì da gāyūtlì lākā kī-kxiātinūk

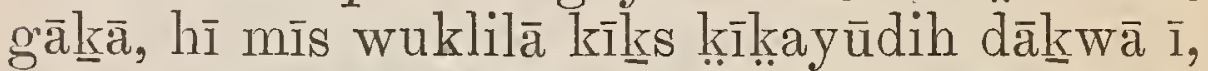
la kauklilā kịks ekiaukstā ì lāh dākzwuk, la wuklāk, māsī da àwīla-kayā lāk wātlduma sints Ilke Gīlkumī.

29 La nīkī Jesus, hī-um awīla-kaȳ da, hūklīlāla yūkl Israel ; kunts Gìya Ike Gìkumī yikîks num ma $\bar{a}$.

30 Glū tlāhwilā nūq klisī tsīs Gìya ūsī da Ike Gìkumī wīlā sīs naukā-yūs, glū wīlā sīs bahwunā-yūs, glū wìlā sìs tlāhwā-yūs, ga-um mākimī"awīlākìs wātldumā sī.

31 Gamīs num sī gada, tlāhwila nūq klisī tsīs bahwitūs, hī qīx ìs tlähwilā nūqīnī nūqūșā sīs hūsūs baß̧wanum ināyā: kīyos ūgwil awīlākāwi sik lāk wătlduma sī da Ike Gīkumī.

32 Lì da l̦ịīīnūk nīk yuk, aulamì Ade, nukā umsīlks la īk nīk kī numā; kīyosa às ùgwila lākī.

33 Glūkss hīma ì awīlā-kāâ̄yì tlāhwila

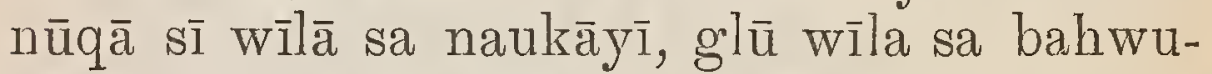
nāȳi, ğlū wīla sa tlāhwāȳi, glū kunts tlāhwilā

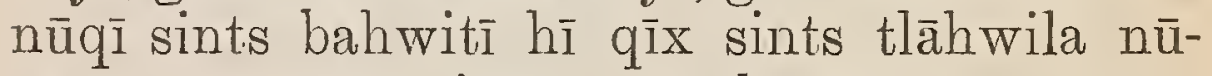
qīnī nūquntsā sints nūsī bagrwanum īnāya lāk nāhwā sīsunāla laqīlāsū zawe knunts Ilke Gīkumì.

34 Gil mīsì Jesus dūqila kīkns nauḳāla ī, la 
nīk yuk, kīsa ākūs qīsātla lākī da gīikāsa sī da Ike Gìkumī, kīyos tā la numūq bagwanum la nāla wuklā sū nūq lāk.

35 Lì Jesus yāḳ̣ugātl nīkia, yịks la ì glīkss-

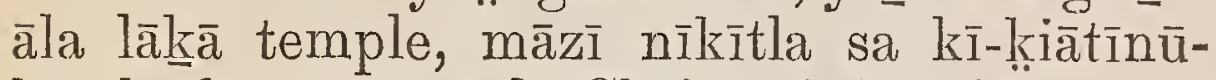
kwāks kwanūqa ì da Christ yis David.

36 Yiks nīkia i David lāki da Holy Spirit,

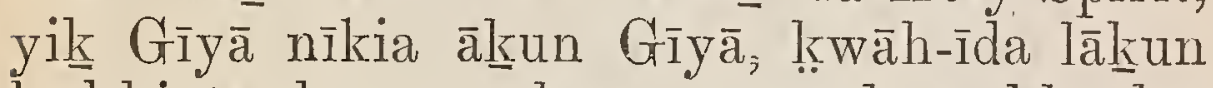
hìtl-kরiūtā kāwāȳ̄, knun wāwasdum kla kīs um-kl tīpdumā mas kla kīis hiyūtūs.

37 Yỉzs hīma ì David glīkulas Gīȳi lāk, wa māzau tā lāgītl lāknās k kwanūq lākss: la ek um hūklīlà sū sa līinum bagrwānuma.

38 La nīk lāh dāknwuk, lāknis glīkseāla īnā-

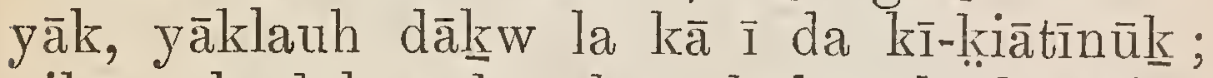

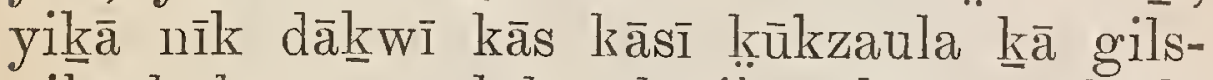
giltā ḳūkzauya, glūkss ehwïla ì kās gāgīlšsīla sū wī lāk lর̣àyasa sa bībagrwanum.

39 Gla wì da nīnālāla-littl lর̣waās lākz̄a kāpīkawāzī, gla wa mīmākimāȳ kịaās lāknā k़wìlasis.

40 Yik̄ā wāwīlūklek gūqā sa kīkaḳiaus,

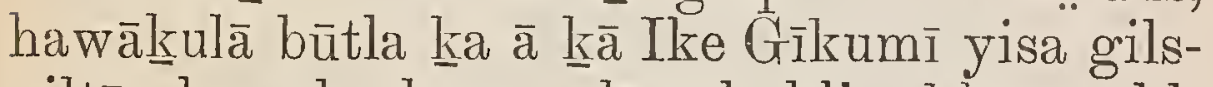
giltā hawākn-ulāyau, lāgîtl klis klūma klī ḳịlāgāy ù klālk.

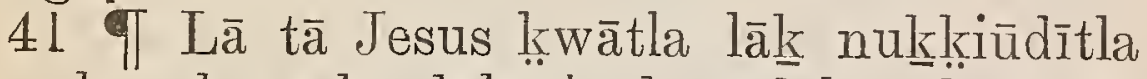

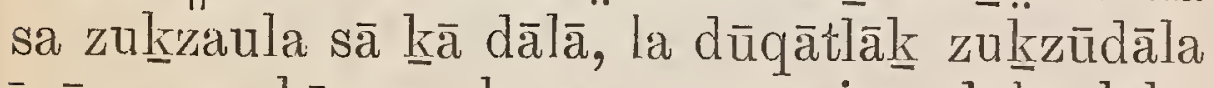
ināya sa kīnum bagwanum yisa dāla lākēa zukzzaulasī, la mīs kīnumī da knịkalkayā $\bar{d} \bar{i}$ zukzzaula sa kīkunum. 
42 Gākna à sa wīwūsīlakā kaḳiaus, zuǩkzūd

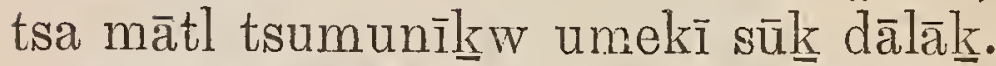

43 La klīlāla knis disciples kāa gāknīs lāk, la

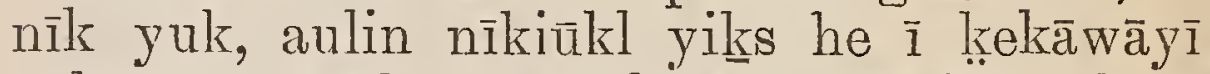
zukzzūyaus gāda wīwūsīlākāl zidāk lāk nāhwā zukzzaulāyū sa zukzzaule knwā gāyāzī k.

44 Auma à glas kxịkayādisīla sīs zukzaulayūh dāk̂ī, lä glā tā gāada zidākuk wāh um

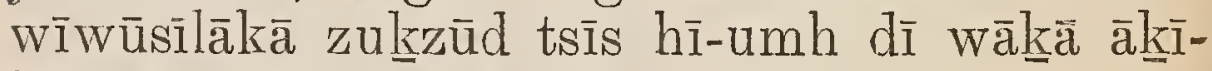

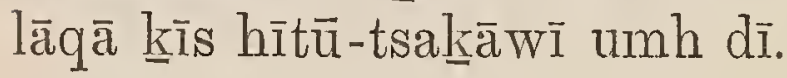

\section{CHAPTER XIII.}

WA gil mīs lāwils lākña temple, la āsī da numūqì lāk disciplesas nīk yuk, Ade, dok

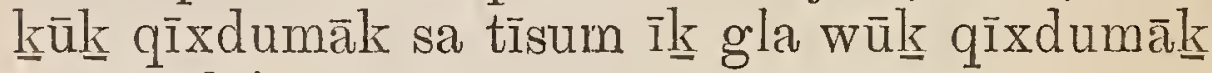
sa gūquī !

2 Lì Jesus nīk yuk, dūqiilā mā sī k kwā awāwìk gī-gūqa à? kīyos-kl numskumā yāwīklisa tīsum īk muqsumālīs-kl kna ūgwilă, yiknā kīs kla klīhiākzūyū-kl.

3 Wa yilkss lā i ḳwāskumā līsūk nuges Olives, nukkkiūdissa sa temple, lì Peter glū James glū John glū Andrew wuklāk,

4 Nìtāla gāknunūh, wìlāq klūk hī qīh-īd klī, mās klī kầ ì māmātltīki klà kū lā klūk da nāhwāk hī qīh-ìd klī?

5 Lì Jesus nānākñī nīk lāh dāknwuk, ȳā- 
ST. MARK, XIII.

klaula āklas nānūtltsīlāq lākss ung we bagowānumä!

6 Kā ìks kīnumī klì da gāke kla lāknun ğī̄umi, nīk-kl, nūgwa-um Christ; là klī nānūt! tsīiāqila kla kēa kīnum klā.

7 Gil um-kl wīsis wuklilā-kl knā wīnāpa

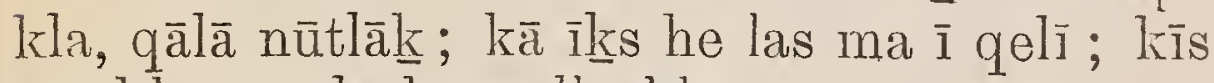
um-kl wīs glì da wnilbī klā.

$8 \mathrm{Ka}$ ì da līlqilāklāyākns wīnì klāk līlqilā-

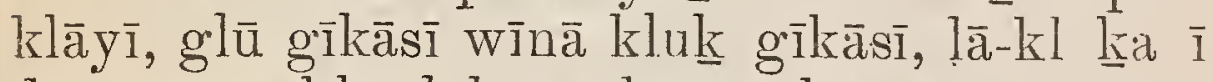
da nīnine kla lāknā àtl-ūgwakīs awīnāgwīs,

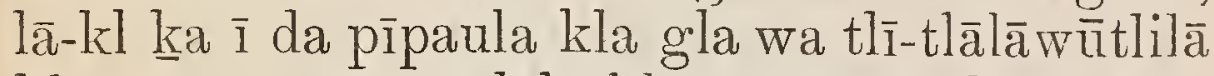
kla, grestā um gālabī-kl sa wīwūsīlākā unk klā.

9 Yāklauh dākew lā hyī glākns sau ìk; kā

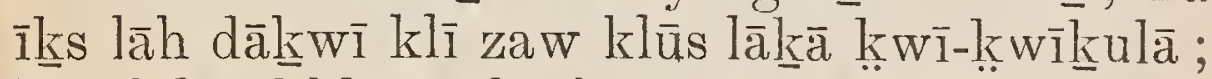

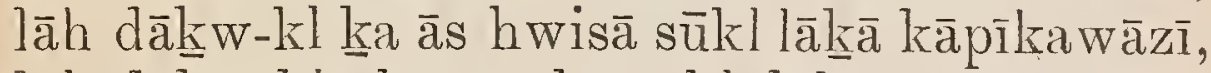

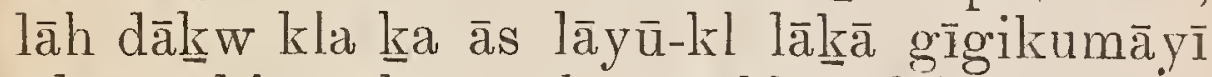

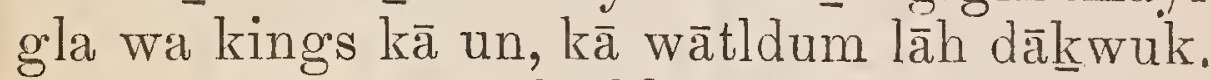

10 La mā wīs gla klī da ek ziḳiālum, lā nīgim-kl lāk nähw⿳亠口冋 lìlqilāklāyā.

11 Gil nāhwā um-kl wìs glä klis lā-kl wāduq-kl kās le zaw ùs, qālà qātlila naukī

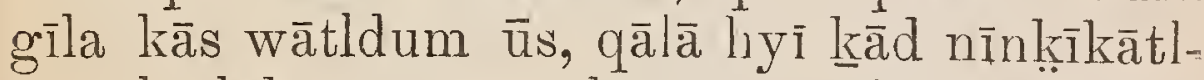

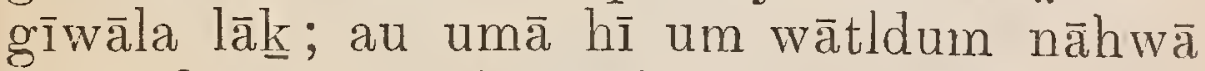

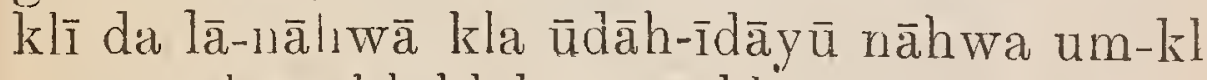
zawe nāhwa klūkl kās wătldum ùs: kā kīzīnāyas sū yāḳuntālas, he àglā sì da Holy Spirit.

12 Wa lā klī da numwiyūt zaw sīs numKWAGUTL. 


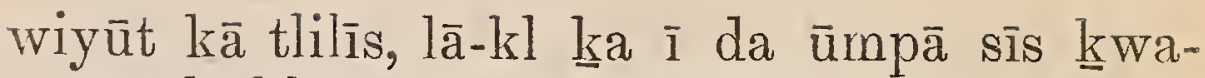
nūqì : lā klī da sāsumī hāyūtā-kl kīis gīga-ūtl nūqī, lā-kl ka ì tlītlilā mas dākww kluk.

13 Lāh dākn kla ka ās klizitl klis nāhwā bagwānum kāan glīkumī; wa yiglā kì da lābund kla tloqātlā-kl, hī um qāqila-āq kì̄.

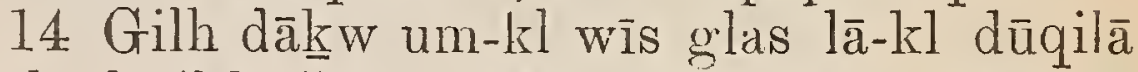
kluk kyil-kyiltī gīlākīs aūzūtlila glāknwàtl lāknīs kīs lākn̄ glākwātla às lāk (wīga hȳ da

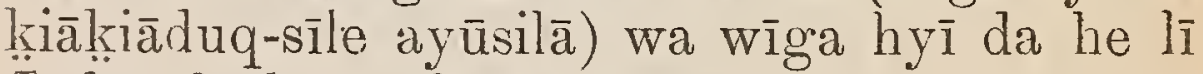
Judæa hītl-tsau lāka na-unge :

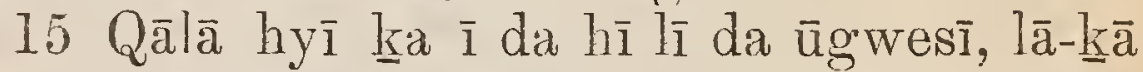
kās la-îkli lāk, kä̀s ukawilsā sū nūqi lāk lākīs gūqui.

16 Qālā hyī ka ì da hì kla gāk lìs awī-

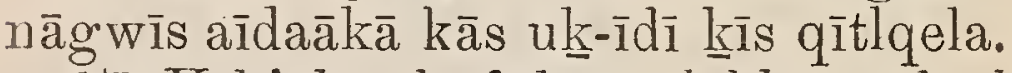

1.7 Kīkiālāsūh dāknw glākl tsī da bībawĩq kla, glüh dākw klī da gīgintlilā kla lāksi da hīh dum kla qīh-īd klī!

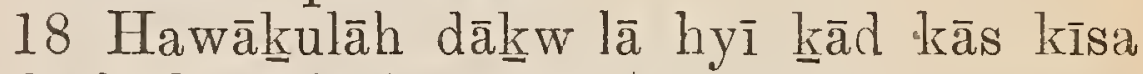
ùs hī hītl-tsauh dumī da zawunkīi.

19 Kā klūma īnì kla sì da tlālāwūtlilā kla lākī da hīh dum kla qīh-ìd klī, kā kīzīnūkwā

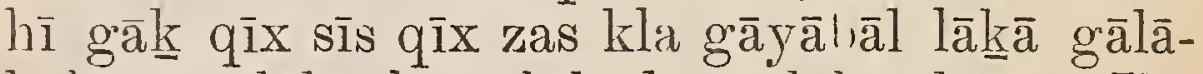

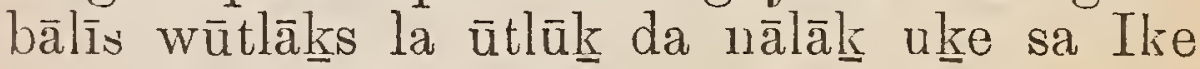

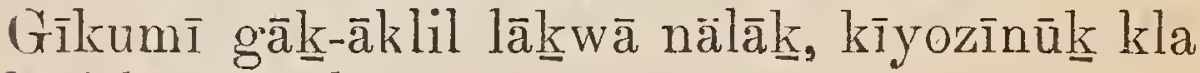
kzàd hì qix klī.

20 Wa kū kīs lākss dī da Gīyā zuḳwāh-ìnā

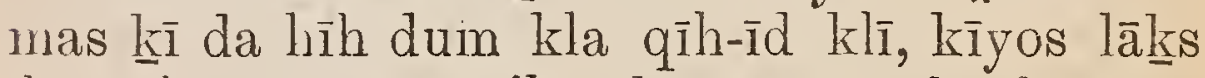

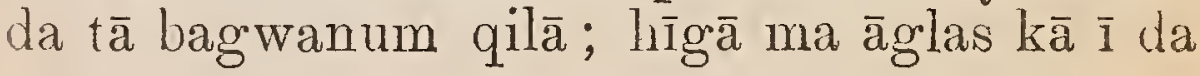


dokūdānum yỉ qayūbuziyāsī, lāgītl tsī zukwāh-īdā mas k ka tlālāwūtiliāh dum kla.

21 Wa gil um lāk wìsis nīk sū lāks ungwe bagwanum, dok, ga um Christ ga, glū lāks nìkia, dok, hī dì da; qā̄à ūqisuk:

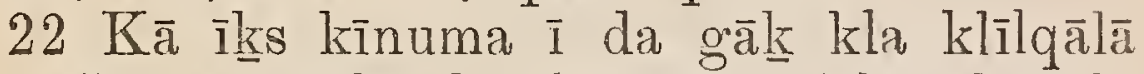
kla Christ būtlā-kl, gla wi da klīlqāla kla pi-prophets bütlā-kl, lầ-kl kna ì dūqa mas kla sīs wunwunhyis kla qigīlas-kl, kunknnyāzīma kla, kās klīqiti tūdā masī, kū qīh-ĩdaās nūq

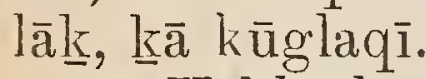

23 Yāklaula hyī glātl, dok, lamun qätlila um nītla sa nāhwā lāh dākwūkl.

24 Lā glā kni da nālā kla hīh dumkl qīh-īd klī, àtlākāwī-kl tsī da tlālāwūtlilāa kla, lā klī da klisila pudih-īdā matsū-kl, lā-kl k ka ì da muqilà kìs là nāqilā-kl,

25 Là kkī da tūtau sī da îḳ̂i tīkumākā-kl, lā-kl knā ì da nāhwā uk sa îkị nutlim gilīis-kl.

26 Wa lā klī dūqilāh dāknw kla knì da

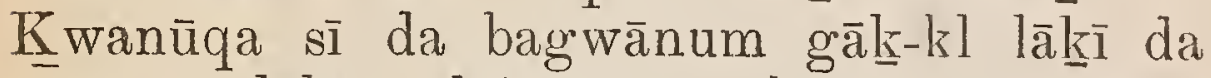
unwāyī lākīs tlāhwāya gla wīs qīxdum kias-au.

27 Wa lā klì yālākn-īd-kl sīs angels, lā klī

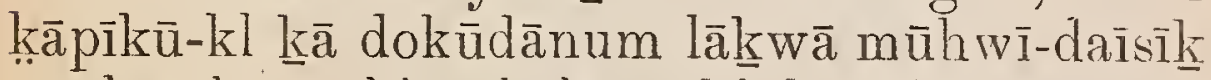
yaulia, ek um-kl gebālī sa kluk nầā, lāgaā-kil lāk ups-bālīsas.

28 Wa wīga ḳākūklā kni da numāhyis dume

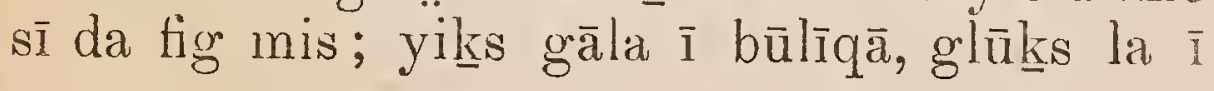


knwāk-īdì māmemas, lāh dāk kīks la mā ī îhyātl hī-unk̄i da:

29 Hī-umklkl wị sis qīh-īd ūgwākā klī, kāsū lākl dūqilālzl knìk hī qīh-īd klī, kauklā-tlāla kìns la mī klī ìhyătlā-kl.

30 Aulā kiasin n̄ilkiūkl, yiǩs kīs mī klūk

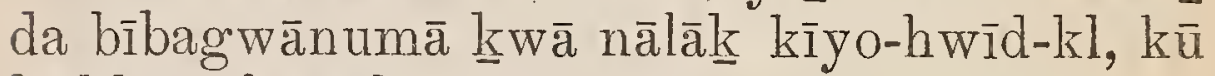
lā kla nāhwā hì qīh-ìd klī.

31 Kā ìni awīnāgwìs gla wa awīnāg wìsin kīyo-hw̄īh-kl; lā glā tin wātldumī kīs kìyohwīda īnūk-kl.

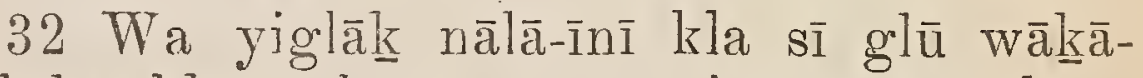
zākīlas kla sī kīyos numūq bagwanum kau-

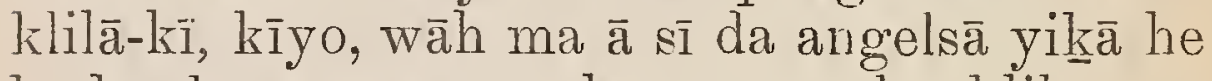
lì da îke awīnāğwīs kīyoza um kauklila nūq sī, kīs um kza à wīsì da Kwanūqī, hīga um glī da Umpa.

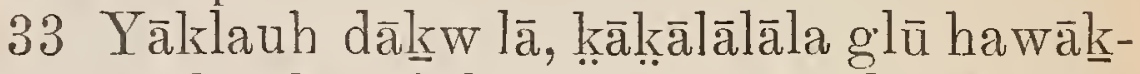
ulākz; kākss kīs dāknwa ākūs kauklilāk hīh dum kla sì qìh-ìd klī.

34 Kā ì da Kwanūqa sa bagwanumks numāhyisā $\overline{1}$ gla wī da bagwanumī la-ās nūq qīsgīla, la wātldum nūq keīs hīlūbātl-zānayī,

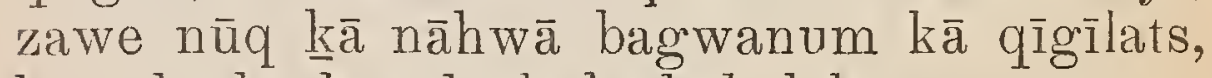

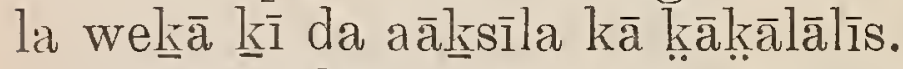

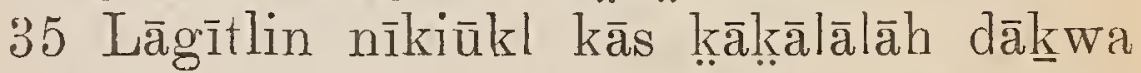

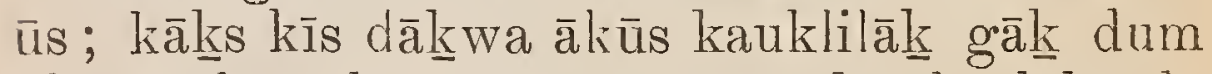
kla sī da gīkunnaya sa gūqī, kū hī lāksī da

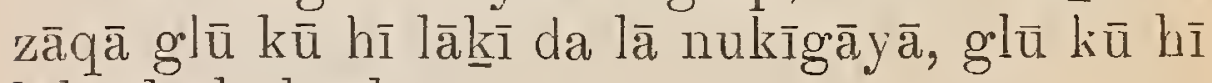
lāksi da lā kaāla; 


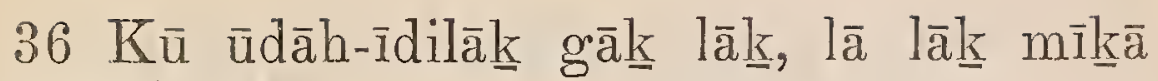
ginsālā-knūkl.

$37 \mathrm{Wa}$ kun wātldum $\bar{u} k l$, nīk um ㅉa à

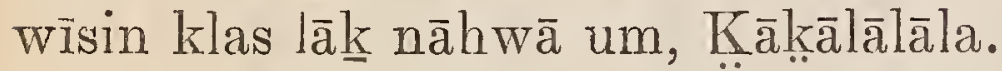

\section{CHAPTER XIV.}

LA qātl mātl pun hwāsa la $\bar{l}$ da l̦wīlasa sa hiyākutl-tsumāyì, gla wī da kīsī bābāwa-āq krwāḳwuh-sumāà : lì da gīgīkumaȳ la-ulbled

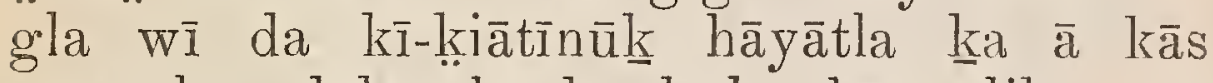

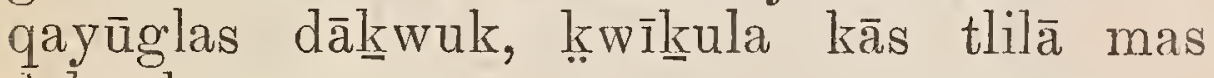
dāk $\underline{\text { injk. }}$

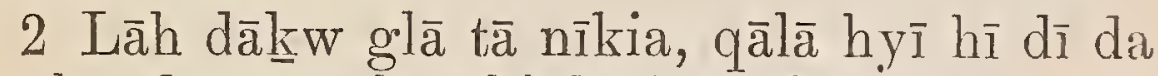

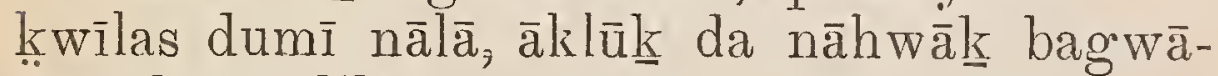
num ks̄umātlìlā.

3 Wa lākns he $\bar{l}$ lì Bethany, lāk gūqus

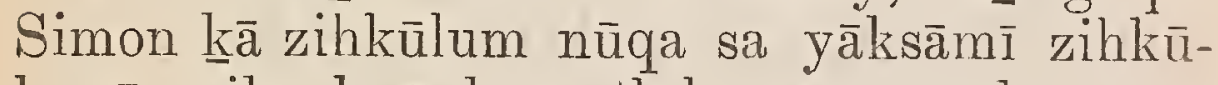

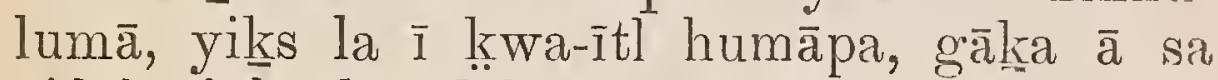
zidāk dālā knā tlāhwila ek-pāla kTātumā, la uk-kiyinduk kās gwuk-īìs lāk hyūmsus.

4 La-ās tlulwīzī-kulī da wa-ūqū k kiwizìtl lāk, nīkia, māzī mūmasīlasū gwītla sūk da klātumh dìk?

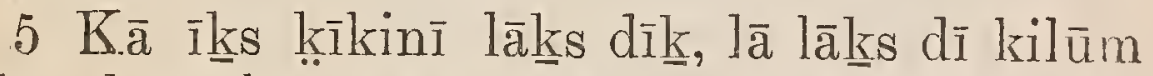

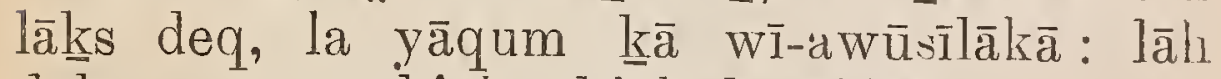

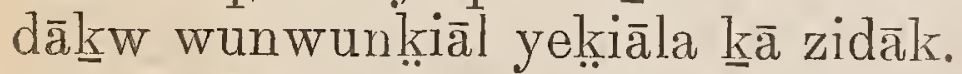

6 Lī Jesus nīkia, qātlas gitālāk gāda zidā- 
kik; māzīs yāwīnāla gịtlā kuk? ekī-gāâs gaa qīh-īdaās gās gāknun.

$.7 \mathrm{~K} \bar{a}$ ìs hîmunātla innīh dāknw mā glūs uKnnūgwā tsa wī-awūsīlākā, hīmī sukns gilh

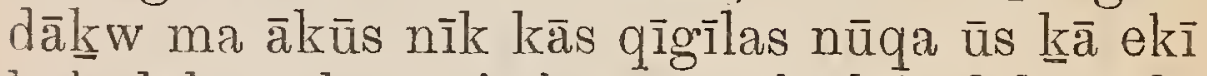

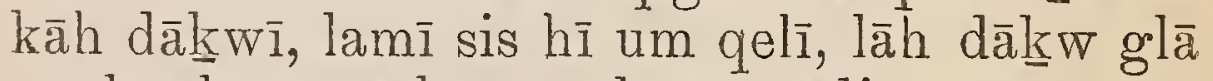
tas kīs hīmunātla-um uknūgowādin.

8 La mī gas gada zidākuk hī qīh-ìdīs lā qîh-îdaāsa: lī gas klātīd gin ūqīnīk kā gū lākl wunumtā sū klū.

9 Aulā kias tin nīkiūkl, lāk nāhwā kla

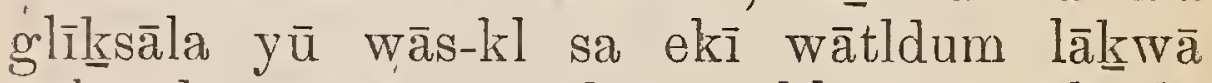
nāhwāk awīnāgwìs, la um-kl wìsī qīh-īda asas gada zidākik' wātldum nāhwā-kl kās

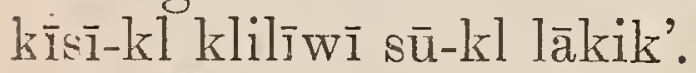

10 Tा La àsī Judas Iscariot knā gāyūtlī lāknā mālūgwigīyū kās-īd kās le lāknā gìgikumāȳ la-ulbled, kās zawes lāh dāknwuk.

11 Wa yih dāknwuk, yiks lāh dāknwa ì wūklilāk, lāh dāknw ekikula, lāh dāknw hutlā-

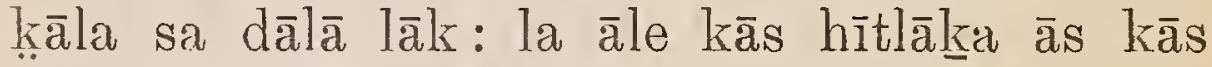
rawes lāh dāknwul.

12 Wa lāk gāāābayī nāla sī da kīsì bābā-

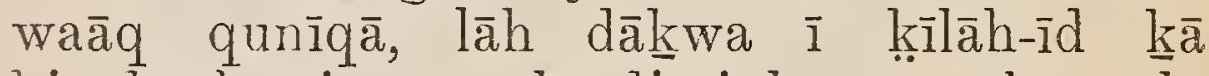
hiyākutl tsimay $\overline{1}$, lì disciplesas nīk yuk, wī dīs qayau ūs kunūh la-as kunūh qā̄îtla mazas k̄ās humaās klūsā kāa hiyākutl-tsiināyī?

13 La yālak-īd tsa mālūqi lāknīs disciples, la nīk yuk, hāgih dāksw la lāke à gūqila, hìmīsis 
lā-kl nākawās-kl gla wa bagwānum nākāzì yinqilā; legī lāk.

14 Wa yik la-îglasas, las nīk kzi da bagwā-

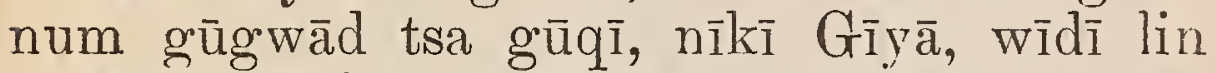
k̦wāgāillas kla un, kưn humaās klā knā hiyākutl tsimāyī gla wun disciples.

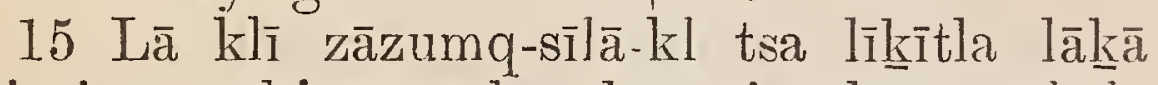

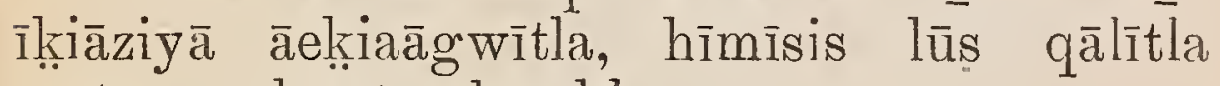
matsū-wī kunts uk kēaskl.

16 Lī disciplesas kās-īda, gāk lāk $\underline{\text { an }}$ gūqila, la aulāmī wătldumas lāh dāk k̂wuk, lāh dāknw qā̄ītlā mas knā hiȳākutl tsimāyī.

17 Gākna ās gila wī da mālūgwigìyū kzī da la zāqū.

18 Wa yikns lāh dāknwa ì knwazītl humāpā, lī Jesus nīkia, aulin nīkiūkl, numūqū lūklūk da nītlā kla un, lākswā humāpīk gla wun.

19 Lāh dāknw hwils-īda, lāh dāknw klāklāyūqil nīk yuk, kịisa nūgwa à.

20 La às nīk lāh dāk̂kwuk, numūqu lākswā mālūgwagīyūk lāk gāda zibāzìk.

21 Kā i ks hīma ì qīyuttlilatsa Kwanūqa sa bagwānum kiāduq mī kā ì : lamīs gla wīw $\bar{u}-$ sīlākà klì da bagwānum lāknūis! ekî lākssdì kā ì da bagwānum kū k̦īs gāâk māyūglumū.

22 Wa yikss lāh dāknwa i humālā lîtlà, lì

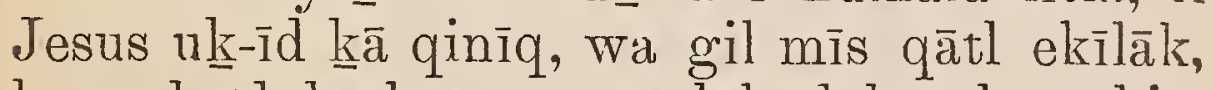
la wuh-īduk, kās zawes lāh dākzwuk, nīkia, uk-ìdāq, humh-ìdāq, gamun ūqīnīk. 
23 La ukk-ì knā nākāstāla, gil mīs qātl mūmul-ḳiāla, la-ās zaws lāh dāknwuk, lāh dāk̂w wīla-um nākn-īd lāk.

24 La nīk lāh dāknwuk, gamun ulqāk yisī

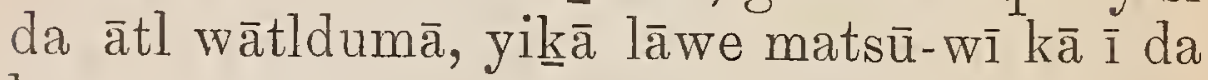
kīnum $\overline{1}$.

25 Aulā kias tin nīkiūkl, kṇ̄s klin lākl ìtìdkl nāk-īdlkl lāk k klūklapìmasa sa knwākeula, àtl um klin kla knī da nālā kla kunklü lākl nāke-id kluk ālūmasa lākni da gīkasa sī da Iḳe Gỉkumī.

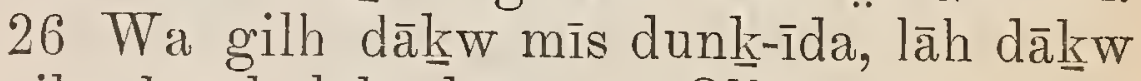
lawilsa kās le lāknī da nuges Olives.

27 Lì Jesus nīk lāh dāknwuk, nāhwāh dāk um klis wānīk-īd klin; kā k kiādukwīnī mas,

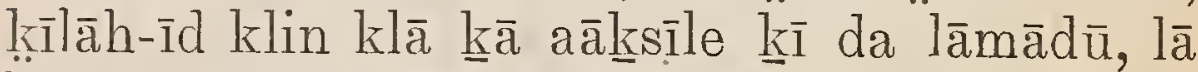
klī da lāmādū lākl gowìtlumīstālā-kl.

$28 \mathrm{Ka}$ glin klū lākl qilāh-īda àgūtl-kl, lā klin gāgălatl gīwī klūs lāk Galìlee.

29 Arumīsī Peter nīk yuk, wāh mī klāk sa nāhwāk wanīkn-īd klūs, knīs glā tā klin.

30 Lì Jesus nīk yuk, aula kiasin nīkiūkl, kīs mì klì da kākāāu mātl pun zāqā-kl, kāsū lākl yūdūh punā-kl hīhwā-kl găknun knwā

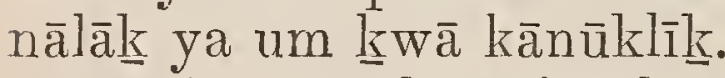

$3 \mathrm{~L}$ Aumīs tlāwīzigātl nīkia, kunklū wāh umkl tlil-kl glūs, kịsà las tin hīhwū-kl, hīmīs nāhwāh dāk kn um wātldums.

32 Wa gāk dāknwa $\bar{a} \mathrm{~s}$ lāka a awīnāgwīs glīkādis Gethsemane: la nīk kīs disciples, yūh dāknw umā knwazīsūk , kun le hawāknulā. 
33 La uk-īduk Peter glū James glū John kà les gla wī, la-ās hwils-īd klūmā yekilkula.

34 La nīk lāh dāknwuk, la umk klūma wos gin naukīk tlītlālā-īkula: yūh dākw-umas lūk kās knāknālāla ùs.

35 La hī-nāqil qāqüsgīlā-līsila, la humhwwālìs lākā awīnāgwìs, la hawākzula, kā gil mì làkxs qīh-īdaās nūqī tlālāwütlila unk kzās, hekā lagi lāk.

36 La nīkia, Abba, Ump, kīyosa ākūs wāhsūwā, klīk-wīdagāk gada ḳwāstāk gāknun,

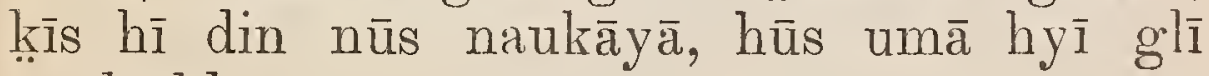
naukī-kl.

37 Gākna às, la dūqila kīkns mīkmakīsa ī, la nīk yuk Peter, Simon, mīknāsa, lamas kīyos

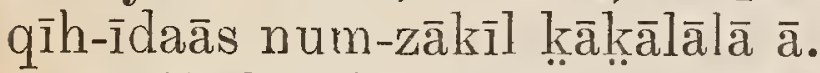

38 Kāḳālālāh dāknw la glū hawāknulāk, kās

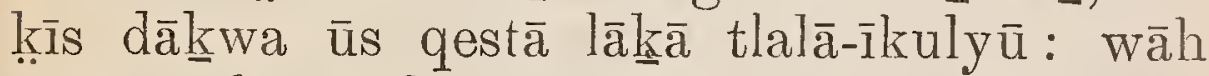
maā sī da naukaȳ suqzā, au mīs weklīmasī da bagwanum īnaȳi.

39 La îtīd kās-īda kās hawāknulī, hī um wātldumīs wātldumh dī.

40 Wa gāk $\bar{i} t \bar{i} d a$, lāh dāk $\underline{\underline{k}} w$ um ka $\bar{a}$ wīs

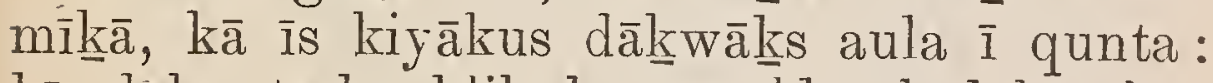
kīs dāknw tā kauklila kās wātldumh dāknwuk.

41 Gāk ka à îtida la yūdūh penīstā, kās

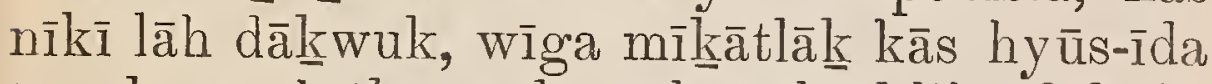

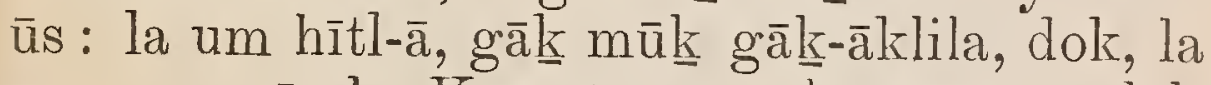

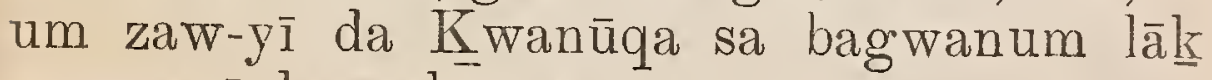
ayasau sī da yaīksāmī. 
42 Glāknwilīs laga kunts lālāgì, dok, yikni da zaw yin gāk mūk.

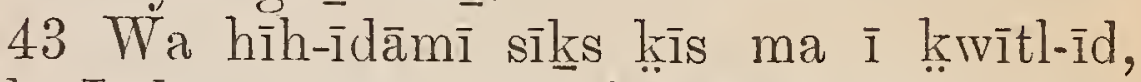

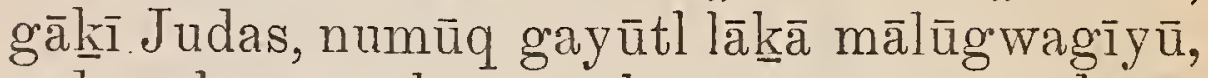
gāk gla wa kīnum bagwanuma qịqik̄āyu wunqila gla wa hwīhweyū, gāyānāqil lākē gīgikumāyi la-ulbled gla wi da scribes gola wa qilsqilyāq.

44 Wa yi k̇i da zawes māmātl-tīkī nūq kāh

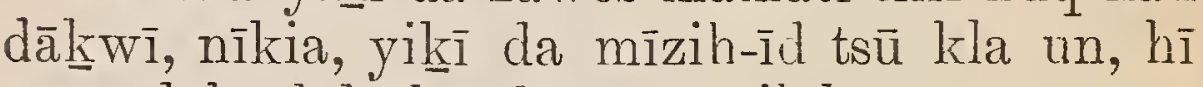
um : dāh-ìdāk, kās lā ūs wātilāk.

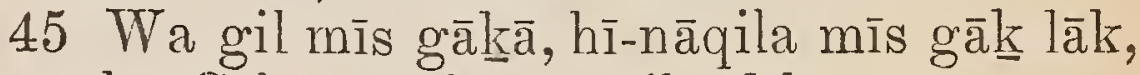
kās nìkī, Gìkumī; kās mīzih-îdìk.

46 Lāh dāknw dāgrāa-klilāk kās dāh-īdìk.

47 Lì da numūqì lāk̄ī da glāh-glawīsī

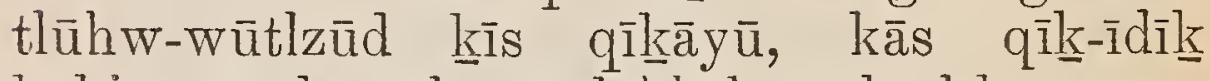

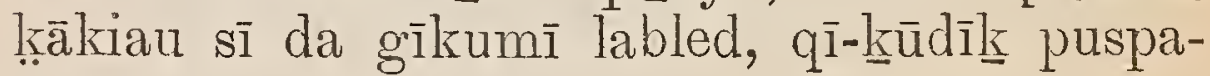
yaus.

48 Lì Jesus yāłর̣gātl nìk lāh dāknwuk, gāk

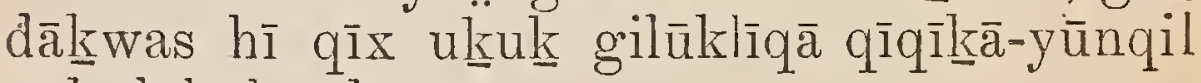
gā $\bar{k}$ dāhīd gākzun.

49 Hìmunātla mīh dìk hì lī da temple glūh

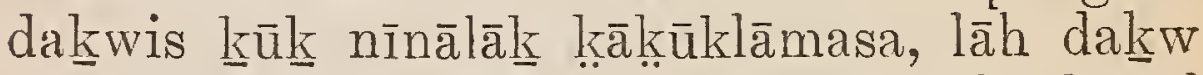
dis kīs dāh-ìd gākzun: lamīs glūk hî lāgîtl

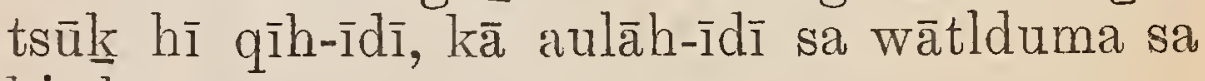
k़iaduqī.

50 Lāh dākn wīla um bos, kās hîtltsū-wì.

51 Lāskumī tī da numūqi àtlūstau bagwa-

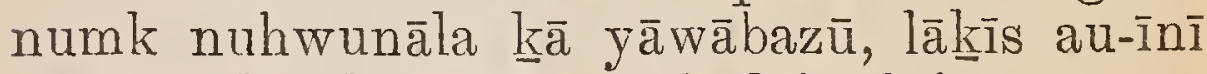
um knānāla: lāh dāknw wāh dāh-īdūk. 


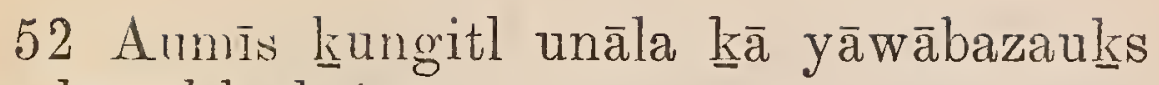
la $\bar{i}$ kānāl hitl-tsau.

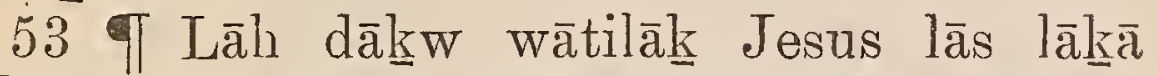

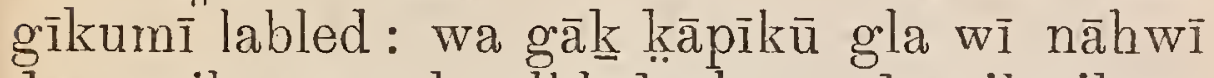
da gīgikumāyì la-ulbled gla wī da qilsqilyāq gla wī da kī-kịiāin̄ $\bar{u}$.

54 Lì Peter lāskumīk qīsāklkleyā, la-īkl um lāk awīkliles dādalīta-āze sì da gīkumāȳ lableda, la qa-îtl gla wì da hīlūbātl-zānāyī, tuit lzā lākè luqītlī.

55 Lamīsì da gīgikumayi la-ulbled gla wī da wākna às māsì da ḳwātla ālek witnessā kā

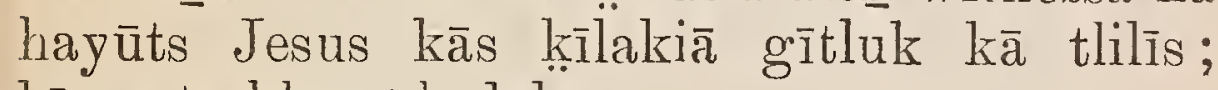
kīyos tā khā sūh dāknws.

56 Kīnum mì sī da wūtl-um nīk sīs wätldumī kā ì, kīyoza mīs nākautlas wätldumb dākwas.

57 La ās glāknwilittī da glākwilittlī, kās

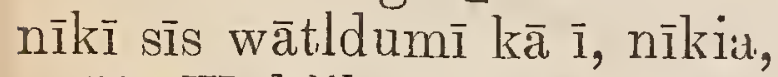

58 Wuklilā-nūhwā kūkss nīkia ik klīh-ìd klin kla knwā umyākulazị knwā āyasūs-dānāk, yūduhw pun hwās umkl kunklū lākl qātlā mas kluk ūgwila um kla kị̄s-kl àyasūs-dānākl.

59 Kīs dāknw um ka à wisis wātldumas nākautla.

60 La às glāk-wālittī da gīkumāyī labled

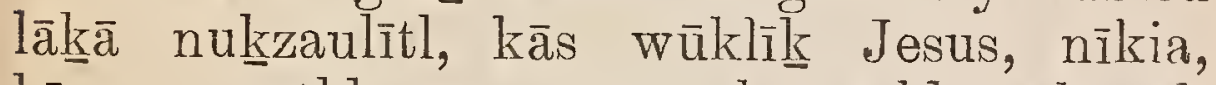
kīyosas wātlduma ā, mā sūk wātldumāk sūk da lūkl.

61 Aumīs ḳwīklātla, kīyos wātlduma: la 
îtīdì da gōikumāyī labled wuklāk, nīkia, sūma $\overline{1}$ da Christ $\overline{\mathrm{a}}, \mathbf{K}$ wanūqā sì da Ekī̄.

62 Lì Jesus nīkia, Nūgwa-um, lāh dāknw mīsis dūqilā-kl kī da KWanūqas bag'wanum kwātlā lāk hītlḳiūtl-zañe sa Tloqīmas, gā̄k bunūtlī̄ā-kl lāk unwāya sa $\overline{1}\rceil \underline{1} \overline{1}$.

63 La āsī da gīkumāyī labled qāpìd kīis qîtlqela kās nīkī, mā zints wūtlittl um kla nīk kunts witness nūqì.

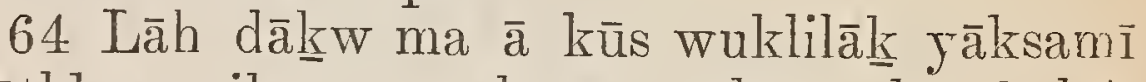
wātldum sik, mā sūkss nīnaukāyā kūs? lāh

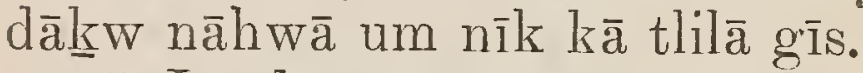

65 Lì da wa-ūqì qịqisumh-ìduk glū nāhwūmduk glū māhyāpuk, lā ka à nīk yuk, yāḳuntāla laga: lamīsì da hīlūbātl-zānī lklākāpuk.

66 T Wa lāk hī-īnāyas lī Peter ì da auks̄a-

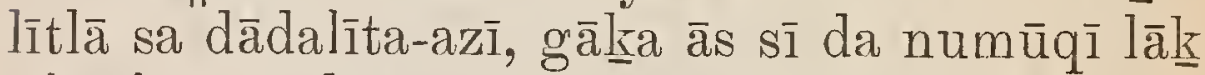

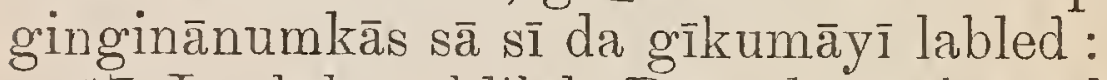

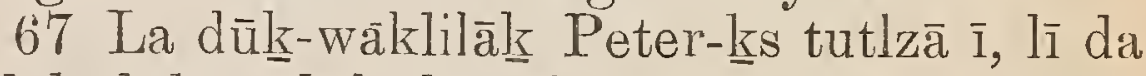
ridāk dūk-wīduk, la nīkia, sū dis̄̄ Nazarene yik Jesus.

68 Aumīs hīhwā, nīkia, knīisin mātltelāk, knìs um ka à wīsin kauklilāks wātldumā kūs: la lotlzaulitl kās le lāknā klāsihsaulitl, la āsa

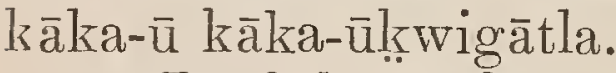

69 La dūk-wāglitl ītīd tsa ūgwila zidākā, la nīk kī da glāh-glawītl, ga um gāyūtl lāh dāknwuk.

70 Aumīs îtīd hīhwā: kị̄s tā kaitluks lā $\overline{1}$ 
da glāh-glawītlì nīk yuk Peter, aulā zau ums

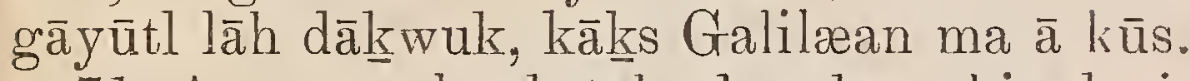

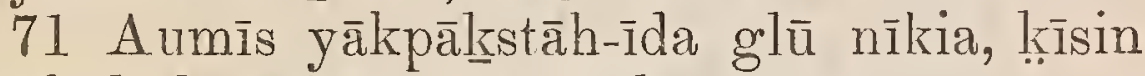
mātltela kwā bagwanumā kūs qayau.

72 La às hīh-ìda um îtìd kāka-ū kwigātla : la āsi Peter mullk-wāklilāk wătildumh des Jèsusāk, kরīs mī klas mātl pun zāqā-kl kāka-ū

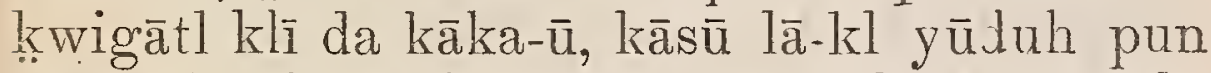

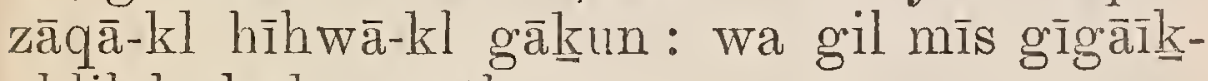
àklilāk, la k̦wegātla.

\section{CHAPTER XV.}

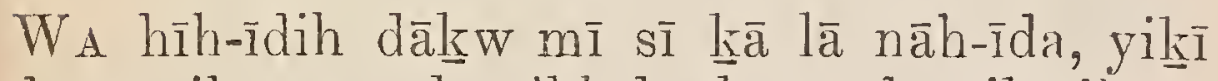
da gīgikumāyì la-ulbled gla wi da qilsqilyāq

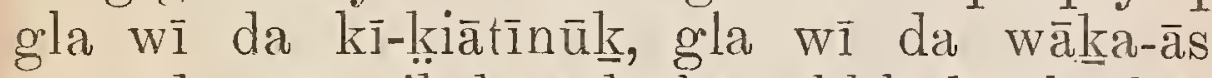

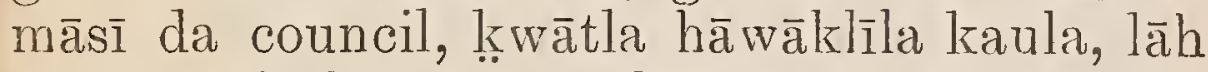

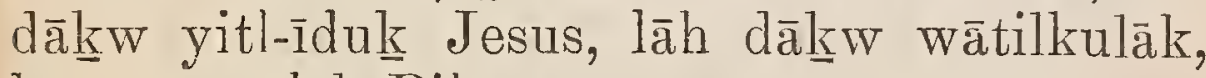
kās zrwes lāk Pilate.

2 Lī Pilate wūklāk, sū ma King sa Jews? İ nānākmī nīk yuk, la mā à kūs nīks.

3 Lì da gīgikumāyì la-ulbled nīk sa kīnım

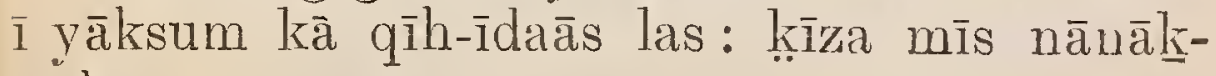
muīk.

4 Lì Pilate itîd wuklāk, nikin, kniyosas wātlduma $\bar{a}$ ? dok̄ūk wăka àsāk sūk wātldum āks kās qīgīlas la-ūs. 


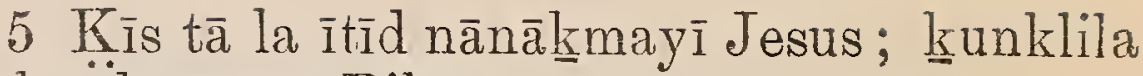
gìtl-tś kzunyāsì Pilate-as.

6 Lā-nāhwā tā lāwilsā mas kēa numūqā knūk kwīlunkīk kāh dākwi nāhwāh dākwas.

7 Là tầ numūqī da hĩ gāâ lì glīkādis Barabbas, wulītl gìūh dākñwi da kzumātl-īdih

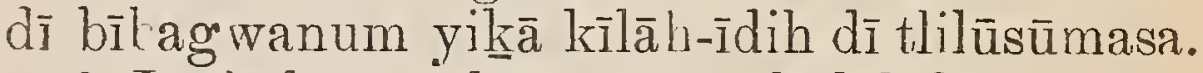

8 Lì da kīnum bagwanum lā lāk kās ukkkiālīk kāa hīmīs qīh-î̀īs hìmunātla-um qīgīlas kāh dākinwi

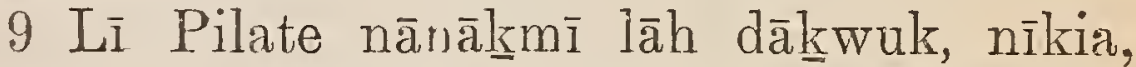
wiga hyin lāwilsa knā King à sa Jews kāh dākws wa.

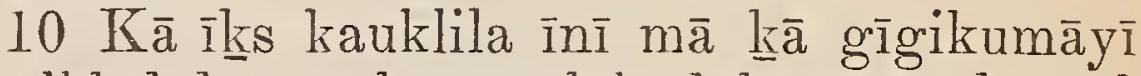
la-ulbledukss ūzakum sīlāh dāknwa às, lā-gītl dāknws zaws lākn.

11 Aumīsì da gīgikumāyì la-ulbled wekkulā knā kīnum bagwanum kā hīmĩs qayūbazì sì Barabbas kā lāwilzums kāh dākzwì.

12 La āsī Pilate îtīd nāuāknki nīk lāh dāknwuk, māzau tin qīh-īdaās klā knis qayūh

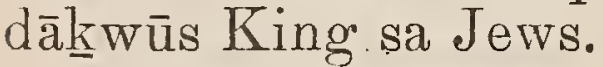

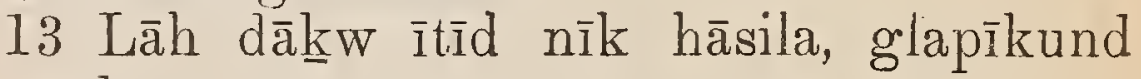
dā tsūk.

14 Lì Pilate nīk lāh dākswuk, kā zì da masa, mā zì da yāksāma qīh-īdaātsik? auh dāknw mīs tloqīmas bāsil nîk, glapîkund dē tsūk.

15 Nìk tī Pilate kās nānākotl tsa-wī k kā 
kīnum baģwanum, lā lāwilsāk Karabbas kāh dāknwī, la zaws Jesus yikss là i qātl hwisītāk, kā lālāgīs glapīkundāyau.

16 Lì da soldiers wātilāk lā lạk knā dādalitailas glīkula sūs Præetorium; lāh dā K̦w klìlātlauk wāk $\bar{a} \bar{a}-\bar{a} s$ sa sa soldiers.

17 Lāh dāknw kẹūkzūd tsa klāqā qîtlqela

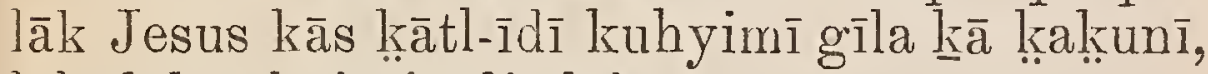
lāh dākn kuhyimdis lāk;

L8 Lāh dāk kw umtlilìtl īạk- kxiālāk, kīlakiasla yūkl Gīikumī sa Jews.

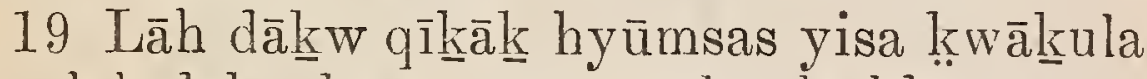
zisī, lāh dāknw ka a quiqasumāk, glū kläqumgālītlila umy āksā būtlāk.

20 Gilh dāknw mìs qātl umtlilītl-ts, lāh

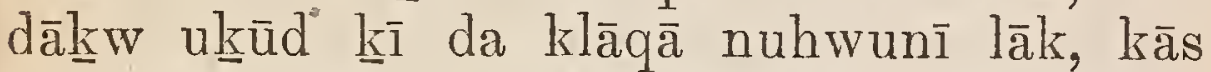

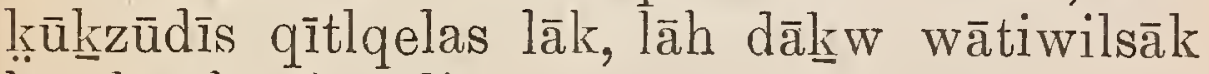
kās le glapīkundis.

21 Lāh dākw tloqā knā numūqī bagwanum, kkāsū-tlila, glīkādis Simon gāyūtl lāk Cyrene, ūmpas Alexander glū Rufus, kā les wìkilā kā kay ūyaula.

22 Wa gāk dāknwīs lāknā awīuāgwīs Golgothah kla, yik awīnāgwīsas knawīq nīkīkss nìkia $\overline{1}$.

23 Lāh dāknw zaw kī sa wine nūnāknūwāq gla wì da myrrh; kịis tā nāk-îduk.

24 Lāh dākn glapīkundis, ġū wāhsīstundik knūkzaweh des, līpā kà is îk dāknw kla lāk. 
25 Lā tā la yūduh-zā-kīla; lāh dāknwā ì glapikundis.

26 Lī da sīnātāk kiātilā-klilā lāk i ikiāyas nīkia, GA UM GIKÜMI SA JEWS.

27 La mīs wa-ūgwâd tsa mālūqi glapikundāyūh dāknws gìs-gilūklīq-da; numūq läks. hîtlḳiūtl-zanes, la mīs numūq lāk kumksūtlzanes.

28 La mīs autāh-īdì da wātldumā sà kị̄âduq

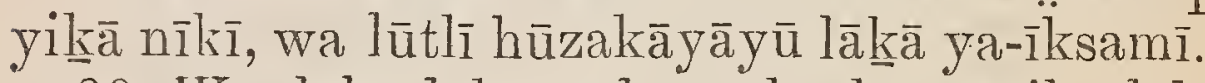

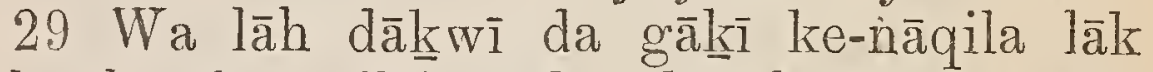
yākpāksstāk, gīsilāh dāknw knīs hyūmsī nīkia, hà ! yūkl kuqā knā hawāknulazì glū ìtūstaulìsā mas kīk yūduhwuksse nāla,

30 Qāqila laga qilixumk, kās gāknākeà ùs lāk knwā kay ūyaulākn.

31 Hī um ka à wīs qịkiāla tsī da gīgikumāyj la-ulbled a-umtlātlas qilīx dāknw mà gla wī da kī-ḳiātīnūk n, nīkia, qāqilīh dek àtlūgwila, lūk̂w kìyos qīh-îdaâs qilīx um qāqilà

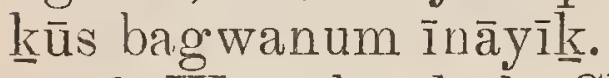

32 Wīga hyūk da Christ i $\underline{k}$, kwwa King ākss

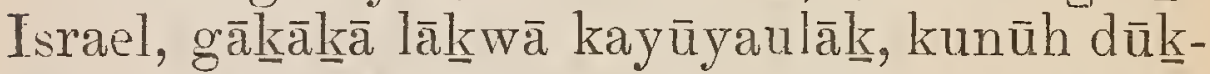
wāklilī kunūh ūqisì : glūh dāk̂kwi da glapī-

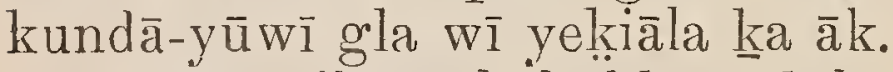

33 Wa gil mīs la kukla-zā kīla, la-ās pudihìdī da nāhwā awīnāgwìs lāga-âklil lāknì da lā nānumā-zā kīla.

34 Wa lākn̄i da lā nānumā-zā kìla, lī Jesus hāsil nīkia, Eloi, Eloi, lama sabachthani? 


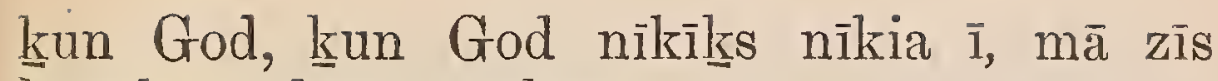
lāgītla qīsdāmas gākzun.

35 Lì da gāayūtlì lāksā glāh-glawìsī, lāh dāk̂kwa ì wuklilāk, nīkia, dokn, lākswālūknwāk Elijah.

36 La āsa numūqi zilhwilīs kās gwakukklūdī sa vinegar lāk k̄ā pulumsī kās ukbundīs lāksā gilta knwāknula zisa, kās zawes lāk kā nāk̂-īd tsūs, nīgitauya, wa untsūs; kunts

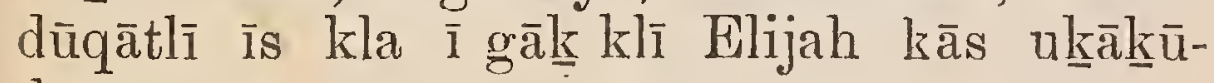
dìqā.

37 Lī Jesus hāsil qāḳluk-glāla, la wịkịkāklila.

38 Lì yāwāpumā lîtla sī da umyāknkulazī

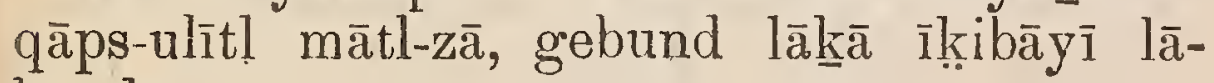
bundā.

39 Wa gil mĩ sì da gīkumāya sa soldiers

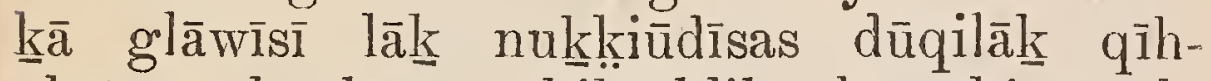
ìdaāsa sịkss la ì wīkikik-āklila, la nīkia, aula um kñ glūk da bagwanumh dì $\underline{K}$ Kwanūqs God.

40 Zì̀āk mīsī da ūgwākē hūmautla lāknăa qîsīnāgwìsī; hīmīs gīkaya à tsī da mālū qui yik Mary Magdalene glū Mary abump dāknwas James yik̄ā hulīyā-kāwàyì glū Joses, glū Salorne;

41 Yikni da, yikns hīmā ūtlī lī Galilee, lāskumìk glū yeklauh duk; hīmī sa kīnum $\bar{i}$ âtl-

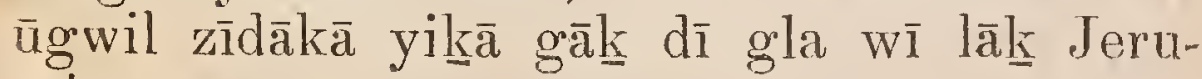
salem.

KWAGUTL. 
42 Wa gil mīs lā zāqa-nāqila, kā qāqatlīlāh dum īnāyas, tlinsā sì da la sabbath $\bar{a}$,

43 Hīmīs la gāk āts Joseph as Arimathra, gīkumāyì bagwanum ìnāyas, yikēa ūgwākā mī

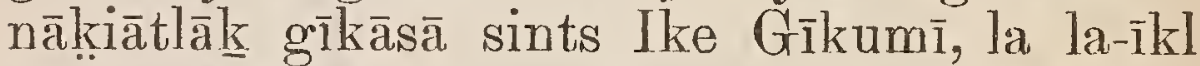
lāk Pilate k़īs hulāla, kās hawāknulīk kā ūqīnāyas Jesus.

44. Lī Pilate kunyāsa sīkss lāgīmūh ma ì ilì̄à: la klīlāla ka centurion, lamīs wuklāk kayūtl umh da ì tlìlā.

45 Wa gil mîs la kautl-āklilāk lāknà centurion, la zaws ūqīnīh des Jesus lāk Joseph.

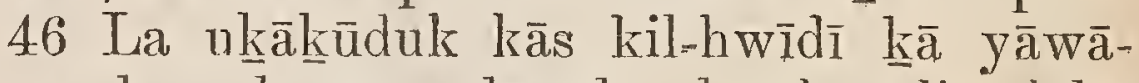

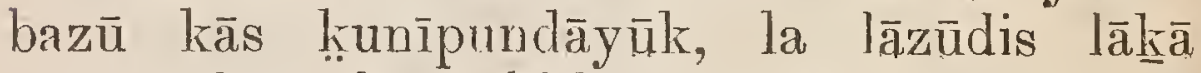
wunumdāsī lāq, klịkuq lākēa tīsum $\overline{1}, \bar{l}$ la lūkwuksstund tsa tīsurn-zī lāk tihyile sa diḡāī.

47 Dūqila mīsī Mary Magdalene glū Mary abumpas .Joses yik uk-ālìlum-asas.

\section{CHAPTER XVI.}

WA gil mīs helk̄ da Sabbath, la-ās Mary Magdalene, glū Mary abumpas James, glū

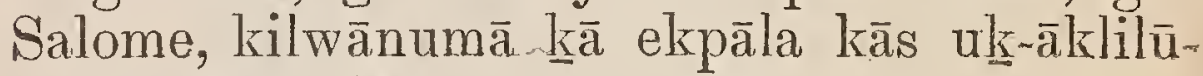
dāyūh dāknw lāk.

2 Kāh-ìd kiās tī kāa gālabāyī nāla sa num 
puna gīla; gāk dāknw lāknà digìā yilkss gāla ì nītl-ĩdĩ da klīsila.

3 Lāh dāknw nīkia, ungwā zau klî lūkwịilisā kla kā tīsuma muqāt]āk tihyile sa digiye.

4 Gilh dāknw mīs dūk-widuk, läh dākw dūk-wāklilā kīkns lamā ì da tīsum ì klịiilīzuqā: yik̄̄a klūme wālas tisuma.

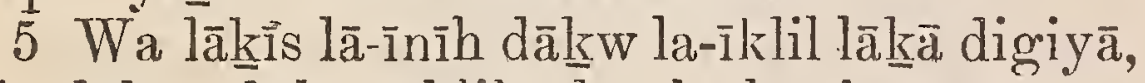
lāh dāk

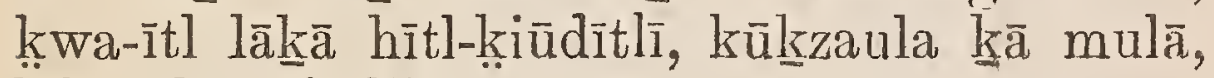
lāh dāksw zindih-īda.

6 La nīk lāh dāknwuk, qā̄à zindikiāk: āleh dāknwa ākūsāk Jesus k̇ā Nazarene, yik̄à glapīkundāyūh de: la mī qilāh-ìda, kīyosī lā lākuk; dok ga, uk-ālìlas dāk go $\bar{a}$ ki.

7 Hāga, nītlāk disciplesas hīmīsī Peter, lamī lā-ḳl gāgālatl gīwī klūs lāk Galilee: hīmīsis lāh dāk wātldum umh-de sī lūkl.

8 Wa lāh dākn yihia-wilsa hît-tsau sa

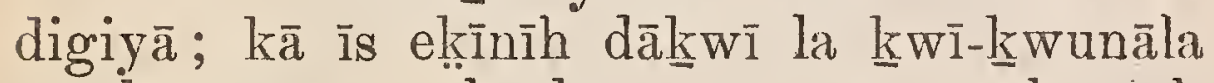
sīs kunyasā $\overline{1}:$ la kīyos numūq nītlā sūh

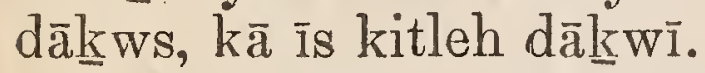

9 ๆ Wa lāk la-īnāyas Jesus qilāh-īd kī da gālabāȳ nāla sa num punāa gīlā, hīmīs gāal nītl-ìdā tsī Mary Magdalene yik lāwe mazas de sī kz̄ uglabū demons.

10 Hīmīs lā nītla kzì da nāmīlelāh dāk̂ dī gla wī yiks lāh dākwa i lulgwătlaula k̦wāsa. 
$11 \mathrm{Wa}$ yih dākw wuk yiks lāh dākwa i zikiātlilā sū sīkns la mā ì qilāh-īda glūkns lamīh-dī dūks:wāglițl-ts, lāh dāknw wayūqisa.

12 Wa la îtīd nītl-ĩd ūgwilātla ma, kā ī da mālūqi lāh dāknwuk lāknis ke-nāqila innīh dākswi là la à lāknà num awīnāgoìis.

13 Lāh dāk dāk w um kna à wìs ūqisuk.

14 Wa ātl-mis gāk nîtlīd lākā numūgwagiyu lākīs la-īnīh dāknw knwazītl humāpa, la-ās

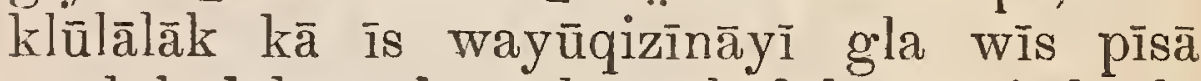
naukīh dāk lā dūqila kīkss la ì qilāh-ìda āgūtla.

15 La nīk lāh dāknwuk, hāgih dāknw-la lāknā nāhwāk awīnāgwīs kās glīkns-āla ūsā sa ek zikxiālum lāk nāhwā bagwanuma.

16 Yikī da ūqis kla glū lā-kl baptize-kl hī-um qāqila-āq klī, wa yị̂̄i da līlāqāla klāk hì-um lā-kl lākē yaksamì.

17 Wạ ga-mīs lā-kl māmātltīkī-kl tsī da ūqis kla; lāwūdāla klī knà demons lāksun glīkumī, yaîkuntāla klis ūgwila kla yākṣundas-kl.

18 Dāgilīsilāh dāknw klịk sī-sītlumī, glū kū nāke-idih đāknw lāk̂kuk tlilūluma nunḳima, kìis dāk̂nw tā klī welā-kl lāk: lā klī pāh-īdih dāknw kla sīs àyasū lākn̄a zihḳā la mīs ekidikl.

19 Wa yiks la ì Gìya ì Jesus qātl-ầīs nìk 


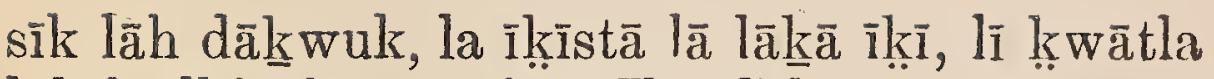
lāk hītlkīutl zane sints Ilke Gīkumī.

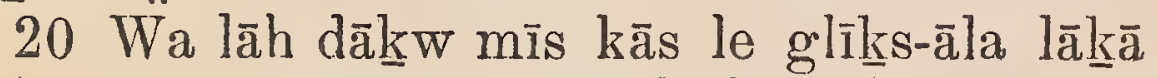
nāhwā awīnāgwīs, yāwī hyints Gīyā glūh

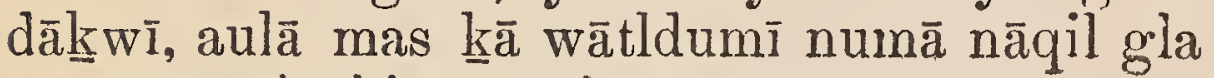
wa māmātl-tîkiayì. Amen. 



Mome?

Procen a

contos

men $* 6037.05$

$9 \longdiv { 9 5 }$ 

SMITHSONIAN INSTITUTION LIBRARIES

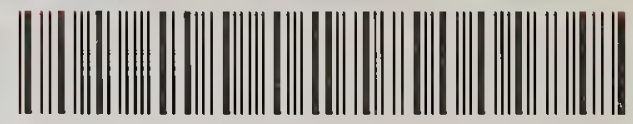

39088005583356 